
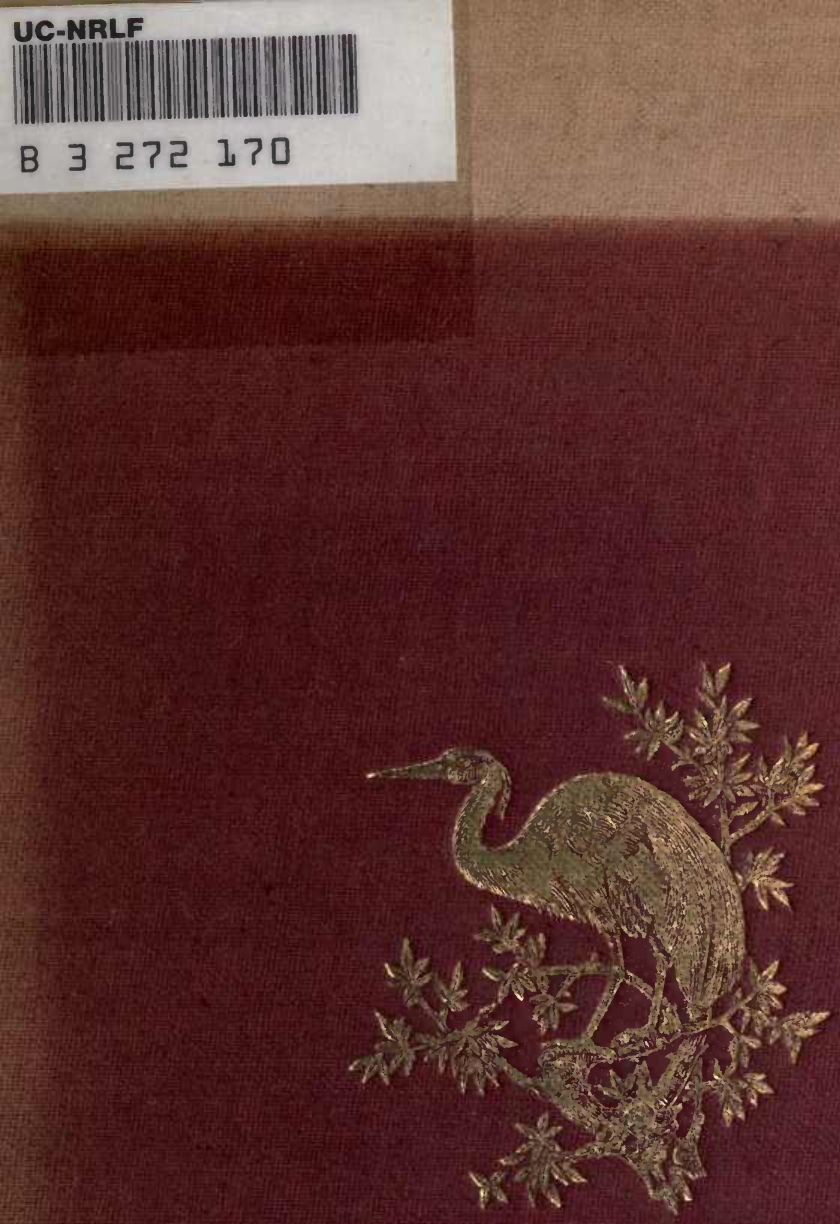

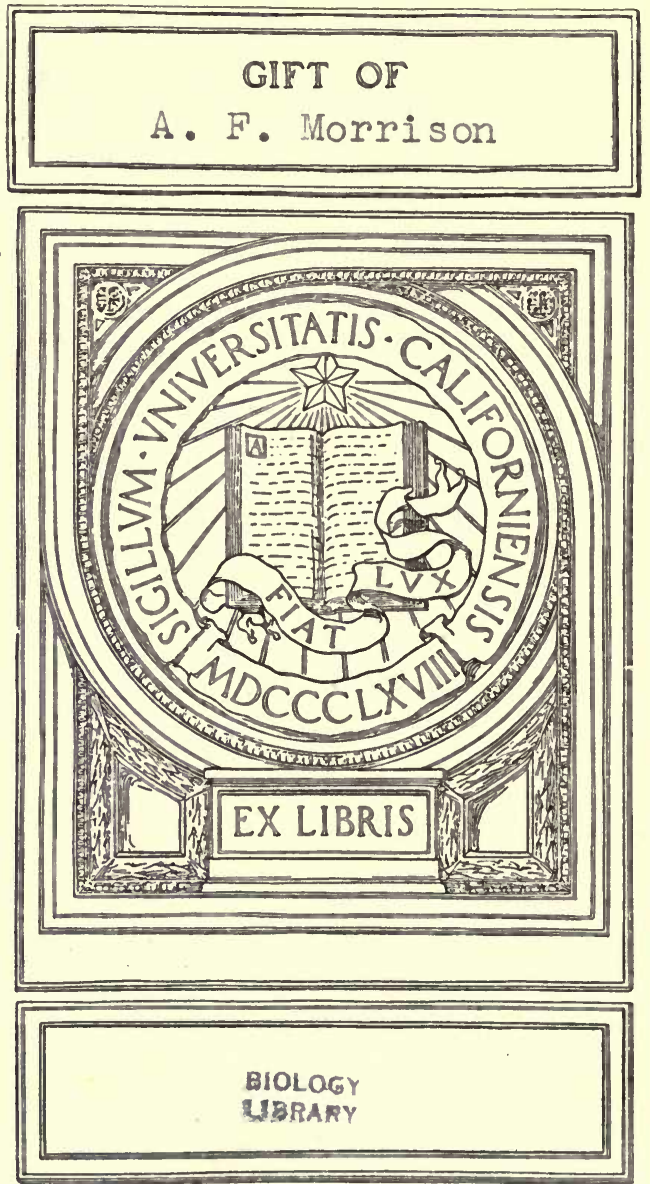


\section{AS.E.LAURIAT CO,
ORTERS $B 00 \mathrm{KS}$,}


$$
5 \%
$$

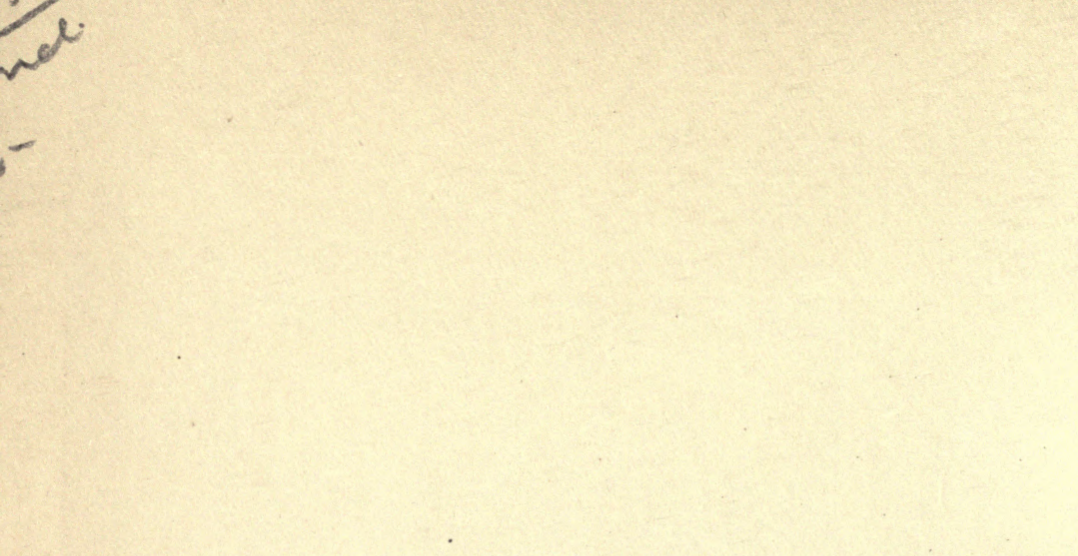

. 



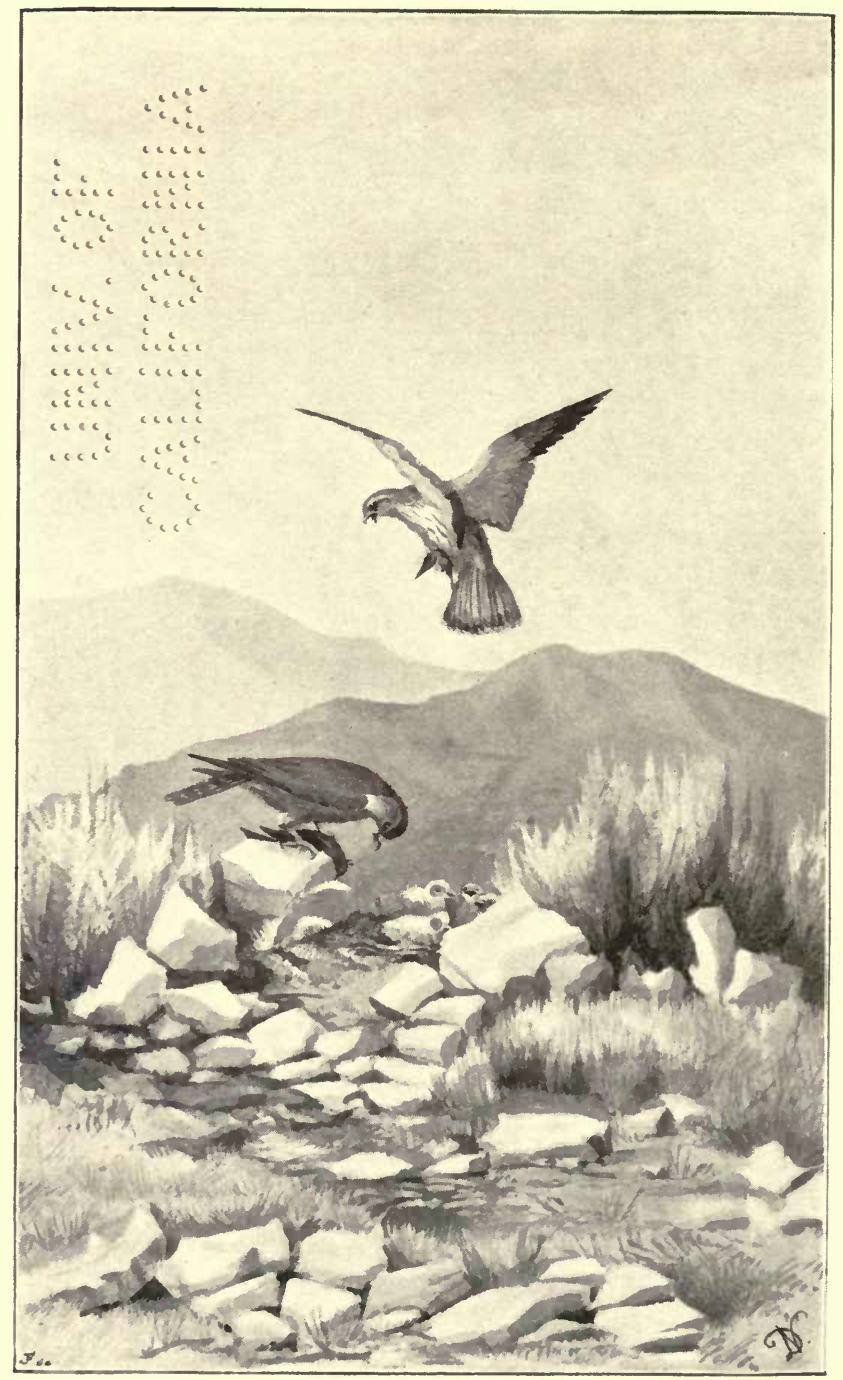

MERLINS. 


\title{
IN THE GREEN LEAF
}

\section{AND THE SERE}

\author{
BY \\ A SON OF THE MARSHES \\ AUTHOR OF \\ Gordens, lienhen \\ " ON SURREY HILls," "WOODLAND, MOOR, AND STREAM," \\ "THE WILD-FOWL AND SEA-FOWL OF \\ GREAT BRITAIN." \\ Edited by J. A. OWEN
}

WITH ILLUSTRATIONS BY G. C. HAÏTÉ AND D. C. NICHOLL

\section{LONDON}

KEGAN PAUL, TRENCH, TRÜBNER \& CO. $\mathrm{L}^{\mathrm{TD}}$ PATERNOSTER HOUSE, CHARING CROSS ROAD I 896 
The rights of translation and of reproduction are reserved.

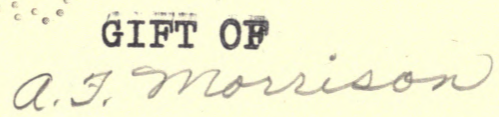

Printed by Ballantyne, Hanson \& Co. At the Ballantyne Press 


\section{CONTENTS}

\section{SPRING}

PAGE

I. THE NEST, SOME FEATHERED BUILDERS, AND THE TRAINING SCHOOL $\quad$. $\quad . \quad . \quad . \quad 3$

II. WOODPECKERS AND THEIR ALLIES • . . 49

\section{$S U M M E R$}

III. ROADSIDE SINGERS AND COVERT WARBLERS . 8 I

IV. DOUBTFUL CHARACTERS: CROWS, MAGPIES, JAYS, AND SHRIKES . . . . . . . . 107

V. PIKE, PERCH, BREAM, AND ROACH . . . I32

\section{AUTUMN}

VI. HARVEST AND GLEANING TIME . • . . 155

VII. LEAFLESS WOODS AND GREY MOORLANDS . • I87

VIII. MOONLIGHT AND DAYBREAK . . . . 207

\section{WINTER}

IX. ROUGH SHOOTING AND ROUGH SHOOTERS . . 235

X. WOODCRAFT . . . . . . . 245

XI. OLD RECOLLECTIONS . . . . . 264 


\section{LIST OF ILLUSTRATIONS}

MerLins

Heading to Spring

Green Woodpecker

TAilpiece to Spring

Heading to Summer

Nightingale .

JAY AND Young .

TAilpiece to Summer .

Heading to Autumn.

Rooks

HAWFINCH

Tallpiece to Autumn.

Heading to Winter .

Winter in the Fields.

TAIlpiece to Winter.
D. C. Nicholl Frontispiece

G. C. Haïté . . 3

D. C. Nicholl . . 53

G. C. Haïté . . 77

G. C. Haïté . 81

D. C. Nicholl . $\quad 85$

D. C. Nicholl . . 117

G. C. Haïté . . $\mathrm{I}_{52}$

G. C. Hä̈té . . ${ }^{2} 55$

D. C. Nicholl . . ${ }^{1} 63$

D. C. Nicholl . . $20 \mathrm{I}$

G. C. Haïté . . 232

G. C. Haïté . . 235

G. C. Hä̈té . . 249

G. C. Hä̈té . . 288 


\section{NOT E}

I MUST crave the indulgence of our critics with regard to a few errors,- - such as "River Sea" (Lea), "roach" for loach, "looping” for loping, "breeds" for broods, and others, which have crept into the Text. Owing to ill-health and an absence of some months from England, I was unable to see the book through the press, which will, I hope, serve as my excuse for some slight inaccuracies of spelling or punctuation.

J. A. OWEN 

S P R I N G 



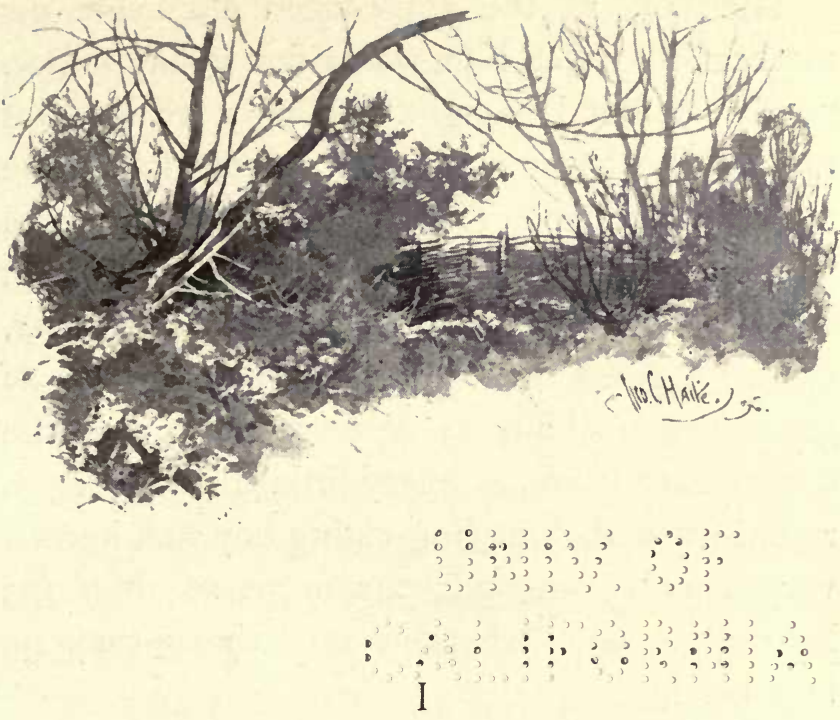

THE NEST, SOME FEATHERED BUILDERS, AND THE TRAINING SCHOOL

Cuckoo, cuckoo, cuckoo, peet, peet, pe, pee, peet, sounds above and around us, as we leisurely pass through one of those long lanes or roads which for hedgerow beauty, and the length of their reputed miles, are only to be met with in woodland Sussex.

"It ain't fur, bless ye. Why, my boy will hev gone back'ards an' for'ards fur two years an' more, night an' marnin', afore he bided there fur good." 
The boy, as the apple-faced old dame his mother still called him, was a fine young fellow, nearly six feet in height, and very strongly set up into the bargain. I was staying for a time in their cottage. This useful combination of strength and stature, together with his keen wits, had placed him in the position of keeper, on the borders of a large estate, a position of great responsibility. A deer-park and the covers near it are, as every little thigh-gaitered, round-rrocked, dumpling-eating boy well knows, very keenly watched; far more so than the lards apprectate wheri at rare times they go bird-nesting.

This border question has been, and will be, a difficult matter to deal with, especially in the consideration of large estates which are bounded by waste grounds to their very park-wall or railings. We must not, however, broach this subject here. Deer and birds'-nests are very different subjects; but had we not been considering the deer, I certainly should not have seen a couple of herons' nests which were just outside the boundaries of that fine domain ; and then the old couple, finding me "chirrupy," as they termed it, on all woodland matters belonging to their immediate neighbourhood, 
gave me some very interesting records of the past, together with their views on present times.

Héronries have, from various causes, become almost exterminated in some places. This has been owing in many instances to changes made when estates which they favoured have changed owners. As our worthy old landlord rightly observed, "Them 'ere herns is niffy things. I've knowed 'em shift from one place twice; once when they felled some timber, an' once when the rooks upset 'em. It was a midlin' chow-row-and-chivy with 'em fur a time. The rooks started it through a-robbin' o' the twigs from the herns' nests ; but they cum back agin. You'd scarce think it, but them 'ere herns kin git about in the trees like cats, an' hold on like 'em too; an' they're the most wicked an' sharp-fightin' things as I knows of. Mother here knows all about it. We was a-coortin' like when that queer job took place. Them young 'uns doan't leave their nestin' trees fur a most menjous long time; the old 'uns feed 'em there, even when they're full-feathered an' as big as they be themselves. My master, as wus then, mind ye, waunted sum o' they big young 'uns fur tu send tu sum friend o' his fur tu start 
a hern rookery, as I calls 'un; so me an' a mate o' mine as could swarm well was ordered tu git 'em out on it. When he gits tu his lot I hears him holler out like mad, an' I see his han' a-bleedin'. Jest as my figger-head showed abuv' the nest, summat went clean through my cap right inter my head, like one o' them 'ere spike nails. It was a rap, I tell 'ee; it was a marcy as I hadn't gone back'ards out of the tree; but as 'twas a fir, I'd got fair holdin'. You should ha' seen 'em nip out; 'twas 'most enough to fritten ye. Their galley long necks was movin' about like snakes, an' they was clappin' and threshin' with their beaks an' wings like mad things. Down we cums tu where keeper wus with a big hamper fur tu put 'em in, an' he sez, 'What hev you bin a-doin' tu yerselves; ye bin climbin' midlin' ork'ard, ain't ye?'

" Then we tells him what they herns ha' done fur us. 'Hev a nip o' sumthin', an' giv 'em another turn,' he says. 'They can't fly; leastways, they wun't. Foller 'em up as fur as ye darest, an' shake 'em off the boughs.'

"So up we goes, downright waxy like, fur what they'd set into us, an' we shook 'em. I doan't think as iver I laughed so much in my 
martil life. They run an' hollered an' walloped about, but they stuck on. Sum on 'em was head down'ards at times, but they niver let goe ther hold; they nipped holt o' the twigs an' branches with their beaks, as well as with their rope-yarn feet. We wus 'bliged tu give the job up, an' I warn't no ways sorry over it ; they'd let us see the natur of 'em."

All the accomplishments possessed by those fully-fledged young herons I could have vouched for, and added to, from my own experiences.

So, as boy Will had told mother on his last visit to her that he " reckined sum o' them old herns waunted tu nest agin' on a bit o' his beat," mother had passed the information over to me, with the comforting remark that "it waun't fur to go."

If eight miles across country, now up, now down, can be considered near, I wondered what the worthy old soul considered some distance away from home.

But the dewy freshness of a bright May morning made up for all fatigue. There were great trees, their trunks in many instances clothed with a luxuriant growth of ivy, with stems as thick as small trees, twining round and about in all directions, the young foliage 
of the trees being brought out in fine relief by the dark glittering green of the ivy-leaves. No murdering axe has ever cut giant ivy cables through at their roots in this district. In past times they were wise in their generation, and that wisdom lingers here yet. Hawthorn bloom, primroses, all the keen odours of growing hedgetangle mingled, filled the air, causing one to feel young once more, in spite of advancing years.

Birds do not sing all at one time; they have their music ready, to be sung to perfection when the hours draw near for it. Small birds with their tender notes fill the great hedgerows with varied life and sound. Chere-e-if-eif-e-if-e, chee-che-che-if-e-twit-twit-ee, che-chetwit-che-che-twit-ee-all this, in a petulant, minor key, comes from some tits that are insect-catching, Then you hear, high up overhead, as he flutters over the topmost shoots of the trees, that plaintive hurried song of the wood-wren; and most strangely mixed up with it, Cheny-cheny-cheny-chef-chef-chif-chef-chef from the hay-builder, as they call him here, the - little chiff-chaff, or, least willow wren.

Twink, twink, twink, then out rattles a short joyous song, for on this glorious morning Beau Chaffinch is full of singing. On one side of 
us, where a copse slopes down to some broken ground, perched on the top of a wild cherrytree, a blackbird is singing with all his heart and soul; the air is full of his rich flute-like notes: then he stops for a time. That glint of light purple and yellow-green at the bottom of the copse-growth shows that the blue-bells are out, and the soft south wind wafts their faint iris-like scent to you, so that you think it is a grand privilege to live.

Old bridges are passed over; one-arched bridges of good stand, that carry the now unfrequented roads over old water-courses which have filled for centuries the vast ponds, that still remain as they were in past days. A mere track-for it is not wide enough to be called a path-led direct from one of those old bridges, with its old oak posts and rails grey with lichens, into a dip or slight hollow. Following this, I came on one of the most beautiful pictures of wood and water combined to be seen anywhere. Fresh green foliage, golden patches of furze blossoms, the ancient mill no longer worked, with the skeleton of its great wheel, of which one or two of its floats are still clinging, were all reflected, as in a polished mirror, in the clear, deep water of that large and lonely 
pond. It was enlivened in some measure by the numerous kingfishers that shot to and fro; not a pair only of birds dashing here and there. I counted six of the flashing beauties at one time. For more than forty years this spot has been noted for these birds; and to those that know it, great consolation can be derived from the fact that they can be seen there now. I have never seen a kingfisher in front of a modern hat in Sussex.

After leaving the "woodland-mirror," our track kept gradually rising, until at last a wide common was in front; a genuine furze common, all ablaze with orange-gold blossoms. After it the ground once more dipped, and there below us, on the borders of a feeding stream, stood a clump of Scotch firs, four in number, their trunks covered for three parts of their great height with ivy. I had at last reached the confines of the boy Will's beat; and a couple of herons were flapping over the flat tops of the ancient firs. Knowing from past experience their wary nature, I skirted the side of the rising ground and came (out of sight, of course) into a line with the tops of the trees.

From my station I could see the feeding stream winding here and there, lost for a time 
to show again like a silver streak; filling now, as in olden times, all the hammer and furnace ponds of that district. From the comparatively shallow waters of the feeding stream the herons were capturing fish to supply the needs of their voracious youngsters, which, in their first stage, look like bunches of tow, with great gapes and goggle eyes. Their fish-spears or bills are very different at first from their adult form, that is, when they are ready to leave the nesting-trees.

Here comes a fine old cock bird; he is pure in plumage, and well crested. As the bird is barely a quarter of a mile away, our glasses bring him close to us. After flapping over his particular tree once or twice, he lowers, lets his long legs down, and raises his long broad wings up over him, so that, when he comes down, his flight feathers will not get crippled by coming in contact with the rough, scraggy top branches. For a few seconds the bird's wings shiver, and his toes feel for the edge of the nest, the next moment he is busily feeding his brood. They are very like rooks in some of their ways, but far more interesting in many of their habits. One thing I can answer for: like the rooks, they do not commit one quarter of the mischief which they are credited with. 
At one time the whole of the low part of the forest through which we tramped home was a wooded swamp, frequented by the bittern. That fine bird comes now, and as a rule remains; but it is a charge of shot that stops him.

Knowing that little ponds, as they are called, to distinguish them from the larger ones, were in the line of our tramp back, also plashes and large water holes, I fancied something might be seen on these waters, or near them. Here, as in other parts of the district, the branches of the trees hang over the water, the path or track running behind the tree trunks. This is very noticeable, for, go where you will in this district, all traces of main roads can be lost for hours.

Herons, woodcocks, and snipes have all brought their young out about here, well within my own recollection. Also teal and ducksthose ducks that frequent fresh waters, surfacefeeders, not divers. In rough weather, when fowl are driven off the sea, and especially when the waters from the weald have flooded the lowland meadows, the fowl gather in hosts-the main body of them. Then is the time to get near them, if you can. But having ways and wills of their own, small parties flit up and off 
from the others and come in over the tree tops, to feed on the still wooded swamp belt. Standing back in the track, only a few feet above, hidden by the tree trunks, if you hold straight and keep cool you will get something. It is keeping cool that pays.

Splash-splash-splash-splash, herik-crik -crik-crik-herik thresh-thresh-threshspatter-spatter. Splash. We slip round some sallow clumps that fringe a small pool. Some creature is there, for the water is ruffled; not ten feet away it boils up, and something like the back-fin of a great fish shows for one moment. We fancy for the moment that we are going to see one of those monster carp, that tradition says live in "sum o' them 'ere holes," when up comes half of a bird's wing, only to go under again. The water bubbles and heaves, and up shoot a couple of coots, gripping each other by the breast. Then over they go on their sides, like fighting cats; one wing of each bird striking away in fine order, the water flying in all directions. All at once they let go, turn round and paddle to the edge of the small pool, and face each other with plumes up and lowered necks. With a paddling rush that makes the water fly, they go for each 
other, shrieking out Curiek-curiek-curiek-crickcrick-crick-crick.

When almost touching each other they throw themselves back on their spread-out tails, drop their wings down to back-water a bit, keeping their heads well back, and strike out with their scratching machines in the most scientific manner; fair one, two given, on either side with wonderful quickness. Holding on to each other, they bob up and down in the most ludicrous manner, looking as if they were trying to dive tail first. Presently one sees a fair chance of fixing the other under the throat with his bill, and under they go again.

No game-cocks nor cast of hawks crabbing over a quarry ever fought with more determination than did that pair of coots. I saw the finish; the one that got the worst of it left the water, and hid himself in some brushwood. Then the victor shook his feathers into order, swam into the middle of the pool, with his plumes raised like that of a black swan, and softly crerked-crerked. There was a movement in some tussocks opposite to us, and out paddled a hen coot to meet her lord, who had been giving such violent proofs that he would not have strange company forced upon him. 
The little grebe or dabchick might, I think, be called a raft builder. Very few have had better opportunity of watching this diver than I have had, and in very fortunate localities. Yet I can only give a few particulars about him, for he gets his living under the water, and the most interesting of his actions are performed unseen.

At various times, in the course of years, I have seen flashes of his or her movements under clear water, as the chances have offered; but they can only be called flashes. Something shoots under or on one side of you, grey or white, as the bird turns and vanishes, and that is all you will see of the dabchick. Even when it has risen close to one, it comes and goes again in that quivering fashion.

The grebes appear to be very erratic in their movements, coming and going suddenly. I have seen nearly thirty on one piece of water at one time, and have gone there again only to see one. In the nesting season this quaint little fellow is certainly of a confiding nature; I have known the raft-nest to be placed within a yard of a well-frequented path round a pond.

Others have flighted off when the evening has closed in, to pick out nesting sites on or 
by the sides of pools, left when the rivers have gone down after floods. Or they frequent some of those quiet pools well covered with weeds in old orchards; and the nest, if it can be called one, is part and parcel of the surroundings. That the nest is wet below, and that the eggs-four, five, or at times as many as six - are covered over with wet weeds when the bird leaves her nest, unless she is frightened off it, every bird-nesting youngster knows well. The eggs are strangely lengthened at one end, very much like some of those oldfashioned pears, called in some districts "ladies'-fingers."

Decaying vegetation naturally generates heat, and a moist heat. From the time that the dabchick's raft is completed, and the first egg laid, there is warmth from the decaying weeds as well as that from the bird's body.

You know where her damp raft is, just under that turf of fresh green tussock blades which droop over it, and you are quite sure that a few yards of snake-like crawling will have to be done, up the low bank that runs round the pond from the meadow below it. The edge of the bank is gained without a rustle; throw your head on one side of some grass tufts, and look, 
there is something under those tussock blades like a water-rat, with only his back above water. One short low hiss_-only a bird's ear could catch it -rouses her, for her head and neck are turned in all directions. Not hearing the noise repeated, she sinks down as she was before. Something appears to move on her and about her, larger than water-beetles certainly, but not so large as mice, and one of the somethings creep up from under her on to her back; she has hatched out, and for once, if you never see them again, you have seen young grebes.

There is something more to be seen yet. If your hands and nose are midge-tortured, put up with it for a moment longer; for one little dumpy diver pokes his head out from his mother's breast, another from under her wing, and two are on her back this time. Now for it ; one long hiss reaches her from our nearly closed lips; for one moment her wings are bluffed out a little, then they close, and her flank-feathers come up over her wings close to her back. Raising a hand, we give one slap, open-handed, on the side of the bank, and like a flash she has gone, taking her little mites. with her under her wings. When they are fit. 
to be left alone a little, you may now and again see the young brood, but very rarely. Young coots and moor-hens are common enough in their seasons, but not young dabchicks. They might have had moon-fern seed sprinkled over them, for, unless they moved, a clutch of them might be under your nose, stretched out, mimicking bits of floating weed, without your seeing one. Their food varies according to the seasons, and their nesting-rafts differ a little, but not much as a rule.

Where raised nests have been found, they have, I think, been caused by the birds and their broods raising them in order to form resting-places for the family.

Birds very soon find out places where they can nest in peace, and they gather there to rear and train their broods; not only in woods, copses, or hedgerows, but on railway embankments, taking little more notice of the ordinary trains, or the thundering rush of the express going at full speed, than they do of the soft winds that gently sway the grass blades which half conceal some of their nests.

Why do pheasants, shy and wary as they are, and partridges leave the coverts and their borders to nest under a self-sown scrub fir, or 
under a small patch of trailing bramble, I wonder? One thing is certain, the broods brought out under these circumstances, and in the localities mentioned, are far stronger than the handreared ones.

Ten miles of railway well known to myself run through water meadows and over rough common lands. It is a branch line, one of the numerous connections of the great traffic lines that run to the West of England. Separated only by a fence from the various properties that the line runs through, that rough wooden boundary is their sanctuary line, and the birds know it, and they take care to keep within its limits.

There is the common song-thrush, with her nest flat on the ground like a lark's, half covered by a young tuft of beth-vine, commonly called by children Old-Man's Beard. It was only when I attempted to stroke the gentle creature on her head with the forefinger that she - moved from her home, which certainly had the ground for the floor. Nightingales, whinchats, stonechats, wheatears, tree-pipits, and meadowpipits are all there, with chif-chefs and willowwrens to keep them company. Firs, self-sown, also furze and luxuriant broom, provide shelter 
from all the winds that blow. Crab-trees in all their glorious wealth of bloom, pink-tufted, brought out in fine relief by the rich waxen green of the young foliage, stand here and there in the hedges that bound some of the meadows, whilst the wild-cherries, the guignes, as they are still called, from their stem formation and the set of their branches, look, when in blossom, like great cones of drifted snow. Kingcups, and the faint tinted cookoo-flowers, show out bravely from the dark green grass over which the swallows are dashing in all directions. Presently a couple come and settle on one of the telegraph wires-the swallow and his mate, in all the sheen of their nesting plumage, that has been perfected, it may be, by the shore of some African lagoon, where the birds that rested in hundreds on the washedup drift had only to move about and pick up at leisure the teeming insect life that frequented it.

With a twitter he caresses her, then he throws one wing out as far as he can stretch it, then the other; after that the long shaft feathers of the tail are preened. But something is not quite right; he seems to think that the under side of one wing is not quite to his satisfaction. When this little matter is 
settled, he launches down from his perch in one long curve, returns again, and hovers above and around his softly twittering partner, spreading his beautiful tail out for her to admire. Then he settles, siddles along the wire, gets close to his companion, and bursts out into song-mouth, throat, and breast in full play, as if he had a difficulty in expressing his heartfelt joy at their successful passage.

In the course of many years I have never seen either nests, eggs, or young quite alike: some eggs vary in the most remarkable degree. Out of ten nests of the tree-pipit, taken in the course of as many years, with their full clutches of eggs (unless I had put the birds off their nests), after watching them day after day, I should not have believed that this collection of nests and eggs belonged to one species, the tree-pipit. But there they are, in one box, duly ticketed with the locality and date of each. All the eggs are different in tint and markings, and all the nests were made out of different materials. This is easily accounted for. Birds build with what they can get, and eat what they can get, each one in its own chosen district. The tree-pipits that nest in the rich grass parks belonging to large estates have very different 
surroundings from those that choose a barren moor, where nothing can be seen for miles but stunted heather and glistening white sand. Insect life abounds in the grass parks and on the sandy moors, so the pipits have plenty of provender; only there is this slight differencethe insect life of the parks is of a mild nature; that of the moors I have found not only ferocious, but venomous, and I wished for more pipits.

That the nests of some birds, either by accident or design, fall in with their surroundings in a wonderful manner, every schoolboy knows. I have seen the exquisite home of the longtailed tit placed in hoary black and white thorns, also in tufts of furze-bushes grey with age, so that ordinary observers would never have seen either of them. But it was only the other day that I saw, in the fork of a broom sprig of rich lush green, a nest of the long-tailed tit, showing out by contrast like a small oval of frosted silver. The little creature had formed the outside walls of the brightest and most silvery lichens and mosses that it could procure from the aged thorns on the common on either side of the railway embankment already mentioned. Although I had seven, if not eight, 
miles to walk home after seeing that nest, the road seemed short for once; for I felt completely thrown on my beam ends, in fact, ornithologically demoralised: all my theories were here contradicted. Old orchards and gardens were near, and old commons; but no, the bird had thought fit to place its nest in a sprig of green broom, where it looked as conspicuous as any nest could look; in fact, two or three sheets of tissue-paper tightly crumpled up in the hand and placed in green twigs would give you a good idea of the little structure.

Once for one whole week I passed by a flycatcher's nest on a level with my face, without knowing it: all that I had seen was a cobweb over a crack in the wall. It never would have been noticed, if the bird had not brushed my face accidentally, as she just left her nest when I was passing. As I stood looking at it, a very old-fashioned youngster who was about marched up and said-

"Well, wat are ye gunnin' (looking) at now ; it's on'y one o' them ere gnat-ketchers' nests ; doan't you touch that 'ere spider's film, what she's hung up there; leastways not if ye waunts tu look at them 'ere young uns, fur if ye do, she'll pisen the lot on 'em, I knows." 
"Well, I am going to try it; there goes the bit of web; you see I have not touched the young ones."

: "It doan't matter, she'll pisen the lot afore marnin"."

As this was in a conservatory where the bird entered from one of the air-holes, I locked the place up in the afternoon, placing the key in my pocket, being quite certain no one except the bird could enter it before ten o'clock next morning. When I paid my visit then the young birds were dead and cold; not a mark on them anywhere, and the old bird was gone. So the boy had the satisfaction of seeing his words proved. This is not a solitary instance; but one out of many. One cottage where I lodged for a time had a small orchard attached to it. As I was passing through one afternoon, I saw the whole of my landlord's family, a boy, aged thirteen, and two girls, aged respectively eleven and nine, in very close confabulation under one of the old apple-trees. On nearing them, the boy told me they were thinking about taking a goldfinch's nest that was in the tree, if the young were "fit."

"I thinks they be, an' I hopes they be, fur if they ain't, an' my han' ony tiches the nest, the 
old un 'ill pisen the lot on 'em." And his sisters chimed in with "Sartin sure she will."

The boy swarmed up like a cat; but he swarmed down again with a long face, for they were not fit to take. When I reached home next day, there was the nest on one of the shelves, and I was told that the old birds had left the orchard.

Scientists try to explain in the most lucid manner some of Nature's mysteries, but all is by no means clear as yet.

How the hawfinch manages to construct its platform of twigs in a tree or trees, as the case may be, in a well-stocked fruit and vegetable garden, without being discovered, is a puzzle. Some of the nests have fair hollows certainly, others are only twig platforms with a depression in the centre. Well-built nests of this feathered piece of suspicion may be seen at times, but they are, I think, exceptions to his general rule.

The astute bird, whose movement at times can only be compared to that of a stone thrown by a strong arm, is watched for at certain seasons more than any other bird that I am acquainted with, and to little purpose so far as the old birds are concerned. Directly a fine lot of table peas begin to fill out, these birds 
watch the crop from the very top twigs of the highest trees, as if they had been told off for that purpose. At the height they sit they might be taken for linnets. When they do come to grief, great care is necessary when shooting, for the precious "marrer" pods hang thick. Locality, the structure of the tree or trees, and it may be, at times, convenience, have much to do in the building of the hawfinch's nest. To say that one type will answer for each species in talking of birds' nests, would be untrue. Perfect types of each species exist certainly, but they are at times strangely modified to suit the builder's purpose. But birds' nests are manufactured, and eggs are got up for those who don't know better.

Proverbs are not always to be relied on. For instance: "Foolish birds build homes for wise hawks to live in ;" and again, "Hawks do not pick out hawks' een." As to the first, the hawks certainly make use of the deserted homes of other birds, and in some cases of squirrels' dreys, as foundations for their own; enlargement of the structures ready provided is often all that is necessary.

The second proverb will not hold good at all ; for it is a well-known fact-at least it ought 
to be by this time-that the peregrine captures the kestrel and eats him, in the same fashion that he would a dove. Yet the kestrel is as true a falcon as himself.

Crows' nests have been given as the favourite foundations for hawks to build on; and so far as a compact piece of bird architecture is concerned, nothing could be better. Now, a few instances of deserted crows' nests being used by sparrow-hawks were well known to me in the years 1850 and $185^{2}$; not in Surrey, but in the wildest and most thickly wooded parts of Sussex, where the raven and the carrioncrow could be found nesting in those years.

No bird builds its nest with rotten twigs. If they are used in its construction, they are wrenched, or fairly bitten off just as the sap has risen to the topmost twigs. Being pliable, the bird can fit and lace in the living twigs and small branches, which can be bent in all directions with the greatest ease. When placed in position, laced and interlaced, the twigs gradually contract as they dry, forming a firm bit of basket-work that will last for years.

The feathered builders certainly lose their tempers at times; but if all goes well, nothing but complacent notes are heard. If a long 
forked twig gets hampered up, then vicious digs are given, and the feet go to work with a will. The other day I saw one of the rook patriarchs, living close to us, in a fix. He was finishing off the edge of his nursery, and had got into a bother with a couple of twigs. $\mathrm{He}$ dug, clawed, yelped, barked, and gurgled in his throat as if possessed. If that rook was not relieving his mind by the use of very unparliamentary language, I am very much mistaken.

The site of a sparrow-hawk's nest having been selected, both birds set to work enlarging it, and forming a kind of twig platform of live twigs, generally fir twigs, all round it. When the young are out, the old birds use the outer rim or platform to place their quarries on, to break them up to feed their young. It is some time before any young bird of any of the raptores can feed for itself. Even when fully feathered, and compelled by their parents to take short flights from tree to tree, so that their flight feathers may get strengthened, they still gather at the call of their parents to be fed. And a well-provided larder is theirs.

Here is a list of the food taken from off rim of the nest of a voracious family of sparrowhawks, two old birds and four well-feathered 
young ones, minutely ticked off after being turned out of a small bag. How I captured them is one of my own woodland secrets :Seven young pheasants, considerably larger than quails, two young partridges, three young chickens, two larks, one chaffinch, one hedgesparrow, and three greenfinches-total, nineteen.

Our readers must not think for one moment that the young birds are allowed to pull the abundant supply of dead birds about. In the morning they are all full-cropped by their parents, and then sent off for exercise. If the wood is a large one, you may hear them calling to each other from different directions. The old birds are fully employed throughout the day in foraging for themselves, and in replenishing the larder.

After the young ones have digested their full crops of food, and thrown up their castings, they are hungry and scream for food most lustily. Then the parents call them, and they make for the nest, where their crops are filled again, after which they perch for the night.

Before the senseless and mischievous custom became common of killing that beautiful evergreen, the ivy, by cutting through its stem, under the impression that it sucked the life out 
of the tree that it clung to, not knowing that the fine creeper, which we think might be called the oak's glory, derives all its nourishment from its own ground-rooted stem, and not from the tree it clings to, some of those ivy stems that I have measured were eighteen inches in circumference just above the ground. Nothing can replace those giant ivy ropes upon the mighty trees that they throw their coils over; and from those dense ivy masses the dwellers in the weald procured their broods of young horned owlets, for the long-eared owls built their nests in them.

The law of self-preservation is said to be the first law of Nature, and all wild creatures certainly do their very best to keep out of harm's way, and to teach their offspring to follow their example.

From the moment that any creature, furred or feathered, begins its life, dangers of some kind beset it; quite independently of man, they have their own natural enemies that persecute them in the most relentless fashion. From morning to night some power, or a combination of powers, seeks to kill, and the hunted ones do their best to avoid the killing. It is an imperative law of Nature that one 
creature shall contribute in some way to the support of another. The bare question of cruelty is not to be considered for one moment ; for predaceous creatures kill quickly, and before the hunted one can fully make out what is the matter it is dead-practice in this, as in other matters, making perfect.

Looking at creatures, however, does not hurt them, and that is all I for one do, and have done for a long time now. How to get near a creature without alarming it is the chief, and in fact the only, thing to remember.

Yet forty years' experience of wood-craft will not-under certain influences, though you may watch patiently for weeks-get you a sight of the badger, although you know well that he and his mate are within a few yards of you ; and again some other time, when you are not thinking about him, he will cross the path in front of you. Here is this creature's home by daylight : a large hole under the roots of a great beech, which on either side run into wild riot; a plashed bank hedge, one to fight shy of when fox-hunting, for the drop is a bad one.

If possible, we wish to see him come out of this when the dew's are beginning to fall. There will be no need to get near to it, for the glass 
shows all that we desire to see. It is a fatal mistake to trample round about the entrancehole of a badger, unless you mean to try and dig him out; for his nose is a keen one, and no matter how gingerly you may step, the soles of your shoes will leave a taint behind, quite enough to alarm him, and he will keep close or bolt out another way. Like the bear, he dashes in and out of cover at times with marvellous rapidity.

We have taken a four miles' walk over the hills and through the woods of a morning, just to look at the entrance-gate of his mansion, and the same distance after six in the evening, on the off-chance of seeing him leave it for the fields of the coombe below.

Over the hill-from which the woods in the vale below are looking like clouds of purple shadows lost in the haze, and far away lies the weald of Kent and Sussex-we slip through the fir-woods as quietly as possible. Kittenlike mewings are heard and sharp snaps. The sounds proceed from one or two breeds of longeared owls, and the snaps from their parents, who are whetting up their bills in pleasant anticipations of their forthcoming supper. From the last of the firs, by a side-track, we gain the 
beech under the roots of which our friar has his home. On our side some of the huge limbs almost touch the ground. Quietly crawling up one of these, we perch close to the trunk and wait.

At times the beauties of Nature are seen under difficulties. The moon clears the shoulder of the hill and rises in the sky, and from the rank undergrowth beneath us the midges rise also. For a whole hour we have to put up with their horrible tortures, until nose, face, and hands get bumps; then with a crash we drop off our perch, and rush out on to the open heath. Not for a sackful of badgers could we bear that torture another five minutes. These midges can make a very purgatory of the woodlands.

The young badgers are carefully tended, and when at play they are most droll in their antics - theirs is a kind of deliberate playfulness. In some counties they are called cubs, in others the young go by the name of badger-pigs.

- I can still talk or write about the Raptoresthe birds of prey ; for the buzzards-both kinds, the so-called common and the rough-legged buzzard-with the harrier's hen and Montagu's harrier, are to be met with in places known to myself. So is the merlin. It is a matter for 
regret that this dashing little falcon should receive the treatment that it has done, and will yet do, I fear. Open moors or stony heath, the haunts of the grouse, plovers, dunlins, and of great numbers of titlings or moor-pipits, suit this bird best. From its habit of resting on large stones, for a look-out over the heather, it has had the name of stone-falcon given to it.

Larks, pipits, dunlins, and large moths, at certain seasons, form the chief food of the merlin. As it nests on the ground, its beautiful eggs when met with are smashed, or at the best taken for collectors. Old and young birds are killed for the same purpose; a few are taken for the sport of falconry, but we fear most go to the bird-preserver's.

Creatures that are formed to prey on others - that is, to kill their own food-show their deep hereditary instinct of fight from the very first. All the will is there, if the power be lacking. For instance, in my time I have kept both falcons and hawks. Some, the most docile, reached me in mature plumage, freshly captured; others I have reared from the nest, when they were in their white-down state. Were they grateful for the care that was given to them at first? Not a bit of it; for the 
young falcons and hawks tumbled over on their backs in their feeble efforts to strike at me whenever I fed them. They would eat all I gave them, but they struck at the hand that fed them all the same. But there are degrees in wickedness, even among birds; and taking all my own varied experiences into consideration, I may say that the sparrow-hawk, for fully developed hereditary cussedness, pure and simple, in a state of captivity, beats all. I am sorry to have to say it ; but it is the bare fact.

The young of falcons and hawks are well trained by their parents: from the time they are strong enough to pull at and break up the quarries brought to them, it is one long course of instruction. The old birds know perfectly well what the young ones will have to do, and they get them fit for doing it as soon as they can. They compel them to take longer flights day after day, and teach them how to stoopthat is, strike at their quarry. One or the other will shoot up with a portion of feather, or it may be fur, followed by the young hopefuls. Then the morsel is dropped from the clutch-down they dash for it, and the one that makes the quickest stoop secures the prize before it reaches the ground. When the old 
birds think the young can fend for themselves, off they go. This is not a case of choice, but necessity, for they are simply cuffed and buffeted off. So well is this known in the country, that it is a common thing to hear a lad say, "Them 'ere hawks has druv their young 'uns off."

Before the chalk-pits that have been scooped out of the sides of some of our Surrey hills were worked as extensively as they are now for lime-burning, several kinds of birds used to nest in the fissures and cracks in the chalksuch, for instance, as owls, jackdaws, pigeons ; and sparrows, as a matter of course. The owls and the jackdaws were permanent residents. Within thirty years I have seen nearly half a hillside blown and picked away.

Blowing, or blasting, as it is termed, is carried on very differently now to what it was in past years. The explosives used are far more powerful, and the firing of the shots, as they are called--that is, firing the chargesten to one times more frequent. Indeed, all matters are now carried on more rapidly, and on a larger scale. The birds above mentioned fight very shy of those places now, for too many "chalk-quakes" are taking place all around them. 
At one time the farmers had their own kilns for chalk-burning, in order to dress the land with it; but they are in ruins-picturesque objects placed in odd nooks and corners of the waste lands. I explore in them frequently, for on and in those old kilns I have seen some fine training going on.

The white owl has been called a church owl amongst his other titles; but a ledge on the face of a chalk-pit suits him to perfection, because there he is practically invisible when drawn up and asleep. For the chalk that has not been worked, it may be for years, or worked-out as they term it, is weather-stained and blotched with streaks of light grey-white and dirty buff. You have seen the owl fly there and settle, but your eyes are not able to make him out till you use the glasses. There he is, a rare bit of mimicry: so well does he fit the corner that you might miss seeing him, though only the length of a small room distant. These peculiar positions, assumed at times for purposes of protection and concealment by the owl family, are proof positive that Nature trains her own creatures to act in the best way for their own well-being and safety. The crows-both the carrion and the hoody 
or dun crows-are, or have been, through the force of circumstances which have influenced them for generations, trained to a degree in the best way of taking care of number one, or two, as the case may be. Although they may appear to be acting with the most perfect indifference when met with-a rare thing now in game counties - they are really watching your movements, in order to see if any harm is likely to come to them through you.

In past years I was fairly well acquainted with crows and their ways: no one troubled himself about them particularly, unless they got at the young chickens on the upland farms; yet, strange to say, all their actions showed as much craft, so far as self-preservation was concerned, as if every man and boy about the place was under a contract to effect their destruction. Now and then a pair got shot, and, strange to tell, these were cooked and eaten.

About the magpie I have a few words to say: he has a reputation all his own for astuteness, which is fully justified by the bird's actions. So very deeply laid at times are his schemes and wiles to gain his ends, that in many places the very name of magpie is associated with something uncanny. 
How the beautiful creature has got mixed up with things evil in woodland traditions, I am not able to say; one thing is certain, the traditions about him are not confined to England. It may be that some of the creatures that form part of the bird's food require a lot of circumventing at times, and that this has developed habits of appropriating unlawfully, of theft and cunning. When shot or trapped-not a common occurrence in some parts now-certain matters are found in his stomach that tell against him a little from some folks' point of view; but then other matters of quite a different nature are also found, which he has also disposed of-and these are quite looked over. One or two men that I know make it a rule to examine the stomachs or crops, as the case may be, of all the birds that pass through their hands in the various seasons: sportsmen-naturalists these are, who keep the record of the various creatures, or parts of them, which are found in these-also such vegetable matters as can be made out. This is very interesting ; but they would not dream of stating that, because certain matters had been found in a bird's crop or stomach, they would always be found there: as the seasons change, so does the food. 
There is stint in Nature's larder. Some birds are about late-that is, as long as the light lasts-others feed by night. The most innocent creatures will baffle you at times, and the more astute ones do so completely.

As I consider him to be one of the ornaments of the woods, I should like to see the magpie where he used to be fairly common. If his training does not suit the present time, that is no fault of his. Strange changes do take place, and one of them may be that the magpie will be cared for before it is too late.

Searching for the nest of birds will very naturally take you into their haunts, and probably get you a sight of the builders; but this is not to be relied on, for the guile of some birds when nesting is beyond common belief.

To a field-naturalist the varied types of birdarchitecture are mysteries that he knows will never be fully explained. There are the structures placed in the trees, in the bushes, and on the ground - a few of them, in the case of some aquatic bird, actually floating on the water; and these are formed by the bills, feet, and breasts of the various builders. If one was asked to select four of the most beautiful nests constructed by our native birds, my choice 
would fall on those of the chaffinch, goldfinch, long-tailed tit, and the golden-crested wren. Under certain forced conditions I have seen in their structures deviations from the general type, but these little details do not count. As a rule, each bird selects its building-place, and constructs its nest on the lines that were first laid down for it in Nature's training-school.

One of the most innocent of feathered builders is the little willow wren, yet it will employ all sorts of wiles and small shifts to lead you away from the immediate vicinity of its nest. Strolling once up a narrow carttrack, closed in on each side by copse growth, a faint cheep just overhead caused me to look up. Then I found that it was a nettle-builder, as the children call it, restlessly flitting from twig to twig, with a small white feather in its bill, that had dropped from a wood-pigeon. Finding that it was observed, it at once dropped down in the undergrowth, where we caught sight of it from time to time, creeping about more like a mouse than a bird; then it flew up into the trees again, still holding its feather. Anxious to know the meaning of these small manœuvres, I hid up in the tangle. Then I saw the bird dart into the bottom of a bramble- 
bush, just in front of the spot where I had been standing. When I examined this, right in the thickest of the tangle, there was the nest.

Watching a pool one morning from behind some cover, a wild duck rose from the rushes. From the start I could see she would pass low down, just on one side of my hiding-place. As she skimmed by, with her wings half bent, not a sound could be heard. Just as quietly, she dropped in the grass not fifty yards away; then peep, peep could be heard. The duck had been down to the pool for a dabble and trimup, coming back to her ducklings in the quiet manner I have described. Birds soon find out where they are safe, and they at once take advantage of it. This duck had made her nest and hatched out close to a lot of pheasantcoops that were vigilantly watched by day and night. The young are carried at times, when necessary; and they follow where the course is clear. More than once I have been asked how water-fowl have got their broods safely into apparently impossible situations. To these questions there is only one answer: we cannot know, for they move them in the dark. In trying to escape observation, which to water- 
fowl at all times means danger, their ways, when once you know them, are much the same. If the wild duck has reason to think that her nimble little ducklings are in danger. you will hear a couple of quacks, the head and neck are stretched out on the water, and then clap, clap, clap go her wings, sending up showers of spray. When that performance is over, you will find all the little swimmers have disappeared somewhere.

The common barnyard ducks I have seen act in the same way, proving that although years and years of domestication have altered the plumage, and very much added to their weight - no small consideration from a dining point of view-the ways in which their ancestors were trained have been transmitted by the laws or rules of natural heredity to themselves.

How strong this implanted instinct is-we use the word instinct for want of a better one - is very quickly shown; for no matter how long creatures have been domesticated, if left entirely alone to their own devices they are soon wild again.

The fox, named by nomadic wanderers the wild red-dog - a fitting title for him - is still held up as a type of all the objectionable 
qualities that it is possible for any creature to have or hold - setting on one side the question of sport which he provides in the season. Tradition has had much to do with thistradition still firmly believed in by some at the present time. All his bad deeds are freely spoken about, but very rarely his good ones. Yet the fox is to a certain extent a killer of vermin; and some of the depredations laid to his charge are committed by other creatures. I am well aware that any question concerning Reynard is a very delicate one to discuss, let alone venturing to write about him; for opinions vary greatly. Wide-awake he is at all times to take advantage of what man may rear and protect for his own especial benefit. Cunning he is in the full sense of the word, but not more so than some other creatures: he has been fixed upon as a very convenient scapegoat, and such he will have to remain.

Turkeys, geese, ducks, pheasants, hares and rabbits, also fish when the chance offers-he samples them all, one must freely admit the fact; but those who have to look after these do their best to balk Reynard in his weakness for luxuries. It is only in starving, winter weather that he will not be denied. 
On the Continent the wolf is credited with all the qualities of the fox, with a few more thrown in; and the wolf, it must be remembered, is really dangerous. Reynard is harmless, so far as human beings are concerned. Those who have had to do with numbers of the wolf family have given them a bad name. The Australian dingo is a bad lot-at least the sheep-farmers consider him as such.

There are various ways of looking at matters : creatures are good or bad so far as their actions do or do not affect man's interest. Wild dogs have been known from beyond record; the wolf, dingo, and fox belong to the family. That they are most clever in a state of Nature is nothing to wonder at, for from that family we have the dog, man's most faithful and devoted servant.

Young animals in a state of Nature, like children, amuse themselves by going through the actions they will most likely have to carry out in earnest after they have left their parents. The mimic fights gone through by the cubs of the fox, the otter, and the badger, end at times in real pitched battle; and their milk-teeth are as sharp as needles. So the little demons for the time being worry, tug, snarl, shriek, and 
scream, until parental authority puts a stop to their unruly behaviour. Like children, they soon fall out: it is a sign of good health. When a quarry is brought in, no matter what it may be-fur, feather, or fin-they are all at it-each one wants more than his mouth will hold; but this fun does not last, for the mother - sometimes the father-breaks it up and divides it in fair proportions. If they do not act as their fond parents think they ought to do, after all the examples set them, they get punished: the parents have two ways of taking a cub by the neck; one is very pleasant, the other is the reverse.

It is interesting to watch young birds. Some are blind and quite helpless for some time after they are hatched; others come out with all their faculties and begin at once to get their own living, for they follow their parents directly. Blind and naked as most young birds are for a time, they know when their parents are coming with food, and when danger is near, by the different calls given by these.

There they are in the nest before you, their weak necks moving from side to side, and all their mouths wide open, for they have heard the feeding signal. But the mother sights you, 
and the note is altered. At once their mouths close, their necks sink down, and in a few seconds they are packed in one close heap. This is what you will see when the young are in this state. After they have got their feathers, although not yet strong enough to fly, and they still keep to the nest, the same note uttered would cause them to tumble out of it in all directions, for so are they trained.

A volume might easily be written about young fish that are hatched out in our rivers, streams, and ponds. From the time they are out in the water they have to look after themselves. How the countless shoals of tiny creatures manage to get on is a mystery; but they do this, and they keep apart. I have seen shoals of young carp, roach, gudgeon, and perch, all in the same brook in various stages of growth, each shoal in that part of the brook best suited for it; and about every two yards a young pike would be seen, six or seven inches in length, either by the side or at the end of some weed, waiting to pouch some of the little roach or gudgeons that might come by. At the time I am thinking of, the water was pure, and the weeds were green; but fish-nurseries are hard to find now, I am sorry to say. 
There is something the matter, and no one seems to know exactly where the fault lies. At one time fish were left to take care of themselves - then they prospered exceedingly; but directly they were cared for, things apparently went wrong. 


\section{II \\ WOODPECKERS AND THEIR ALLIES}

Yıke-yike-yike-yike-yike-yike-yike! rings out with startling rapidity and distinctness. It is the cry, or, as some have called it, the laugh, of the green woodpecker, a bird which, unless you are well acquainted with his habits and haunts, you will hear far more frequently than you can see him; for he, like other members of the tapping community, is continually on the guard against awkward surprises.

When you have him in your hand alive-for he can be procured by the few who are in the secret-the fine bird looks as handsome as a parrot, his plumage being a mixture of greens, yellows, and ashen-greys. The flight feathers of the wings and tail are barred; add to this pleasing arrangement of colouring his crimson crown or crest-he raises this considerably at times-and the crimson moustache edged with black, not forgetting that very keen yel- 
lowish-grey eye of his, and you have the plumage of the yaffle.

After inspection he must, of course, be liberated again at once. And do not let the handsome fellow get a stroke at your hand or fingers with his pick-axe of a bill, for if he does, you will certainly remember it.

There is a rich bloom on the feathers when alive, or just after the climber has been shot, which is never seen when the bird is set up in a case. Your very practical inspection of him being over, when you have observed all his points, and seen him, in his alarm, shoot out that long barbed tongue, place him as you would a carrier pigeon in both hands, and toss him up. For a few seconds he clutters up anyhow, then off he shoots, in long dips or loops, shrieking out his alarm-notes like a red-capped, feathered lunatic.

When he is happy on the trees or on the ground, he shouts out his yike-yike-yike! And when he goes to roost in the tunnel he has formed, or in the hollow of some tree, he finishes the day's proceedings with one short, sharp yike!

Some of our readers might think that from the description given of the yaffle's plumage it 
would be a bird easily seen, but this is not the case ; for unless, as I have mentioned, you are well versed in its habits and tactics, the green woodpecker to ordinary observers would be as invisible as if it had been sprinkled over with the seeds of that plant of the woodlandersthe moonwort fern of supposed mystic properties.

We are sitting under a noble clump of beeches, the rearguard, so to speak, of a wide belt of beech trees which line the crest of one of our hills. It is a July morning, but there is a fresh air stirring, just enough to move the rich green foliage above us, and to let the light play as the branches sway to and fro. Some portions show the softest golden green; this is caused by the light falling directly on themin fact, they are semi-transparent, and as you look up you can see the leaf veinings. But the richest play of colour is on the boles and over the gnarled and twisted roots of these giant trees.

Soft olive and yellow flashes come and go, at one time playing with rapidity down and around the lobes or trunks, then suddenly running up into the foliage, to come again slowly quivering and creeping down the moss-covered roots. 
Where the glorious July sun catches the rough projections of the great limbs and branches, they show out for a few moments like bosses of silver; then the shadow dance goes on again as before, until at last you look out before you on one of the finest woodland scenes that it is possible to see in the south of England.

Our resting-place faces a vast coombe or hollow which is covered with turf, and dotted with thorn bushes; not thickly, but they are sprinkled over, just enough to break the monotony of the turf. Here a bunch of the beautiful bee-orchid can be gathered, and some other plants of the same family.

As to the honeysuckles that climb over the thorns in profusion, the air is full of their rich, sweet fragrance. It is a place to rest and think in through the length of a summer's day, stretched out on the deep carpet of dry madder-brown leaves.

Below us the chimneys of the coombe farm show through the trees. We can see the pewits flapping over the fields, and hear the pewit-witwit-weet of the old birds, and the plaintive, weak, quavering, and querulous we-e-e-e-eets of the young birds now on the wing.

Rich pasture meadows, well watered, sur- 


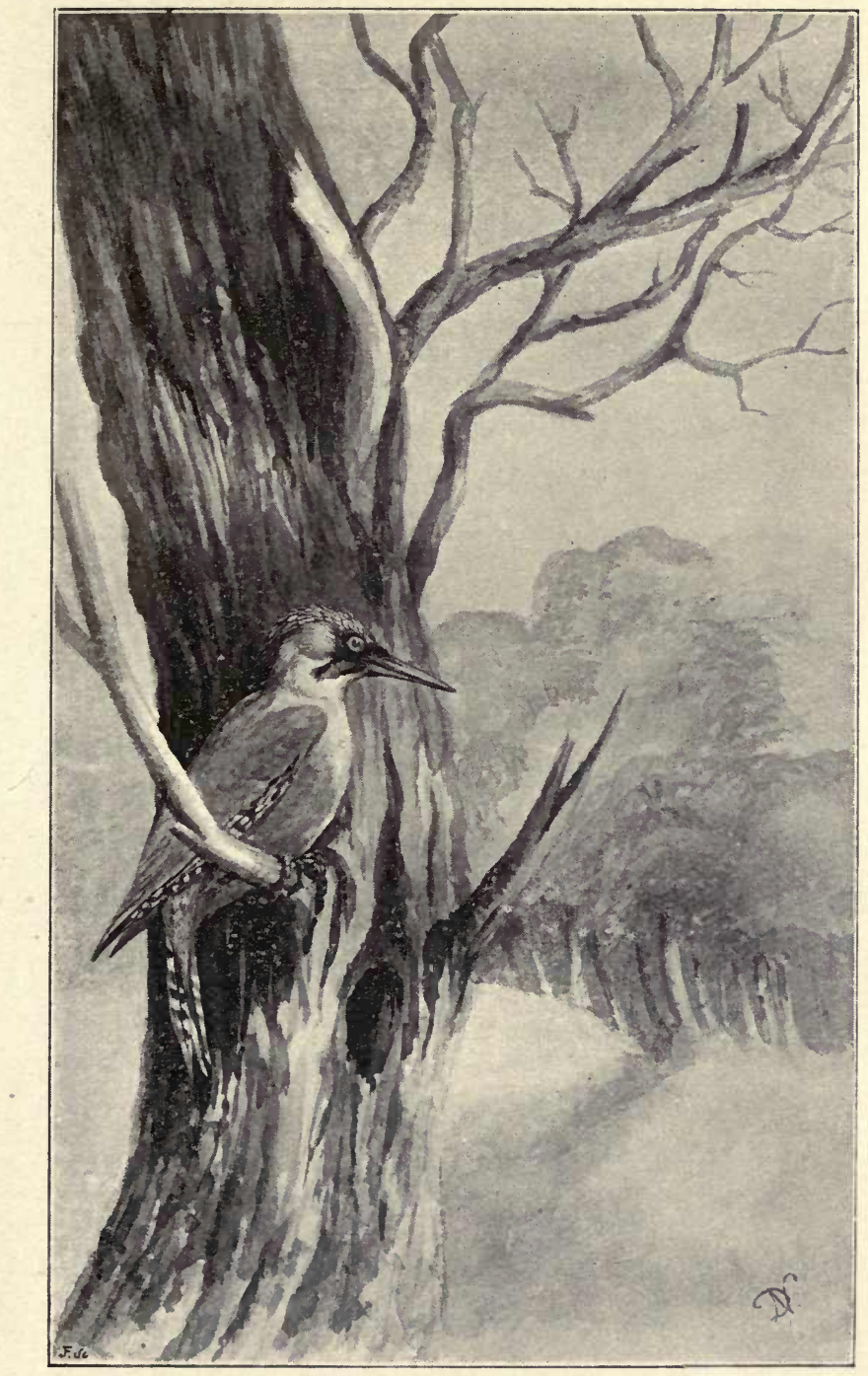

GREEN WOODPECKER. 

rounded by woods and thick copse growth, lead away to fir-covered hills beyond; then comes a great tract of country, once the home of the wild red-deer, followed by St. Leonard's Forest ; and like a dim line of blue haze, shimmering in the heat, beyond all, the South-Down Hills.

Tap-tap-tap - . . . . - tap-tap-tap-tap-tap-taptap-. - . - that sound has roused us from our day-dreams. I had crawled like a cat over the big roots of a tree, and drawn myself up by the side of one of the great trunks.

Tap-tap-tap! comes again, almost over my head; but no yaffle can I see, although a fragment of rotten wood has almost fallen on my shoulder, one that the bird has struck off with his powerful bill. The bird is quite certain that we have not seen him, but he thinks he will have a bit of a shift all the same; so away he goes, scuttling over the limbs and branches, the claws of his climbing machines clicking, as he progresses, like those of a cat.

The shadows dance and flicker; my eyes are tired through peering so much in the evervaried light, and my neck has got a kink in it through craning about. But for all this snaking round and about I have not yet seen my friend, so closely do those olive shadows and yellow- 
green lights fall in with the colour of his plumage. A slight click is heard on the tree next to the one that hides me. I look up, only to catch sight of a tuft of crimson feathers and a keen eye showing over a burr in the bark. The next moment he is off, shouting yike-yikeyike!

The bird's cry rings out from the old oaks, that cast shadows from their overhanging branches on to the pure waters of the mere, which is fringed with beds, or rather sheaves, of yellow iris, clumps of meadow-sweet, beds of purple loose-strife, and bunches of the flowery rush, with a thick growth of forget-me-nots to complete the show.

It is very evident that other birds understand his cry of alarm as he loops himself over the mere to the other side, for I have glided on him without being seen for once; and I have very much startled him.

Wild ducks paddle out from their aquatic covers, followed by their broods of flappers; others spring up and flick away, with the noiseless flight of nesting-time. The herons, those beautiful grey, white, and black waders, spring up from the outer belt of aquatic growth-the firm portion of it, which is nearly solid ground, 
where they have been frog-hunting-to perch on the top shoots of the firs.

The frog, like the common snipe-that in some districts has got to be very uncommonlikes a nice dry place to "absquotulate" in, and to think matters over; for froggy is by nature very contemplative. The herons know all about this weakness of his, and they glide like shadows to where he sits, with his beautiful eyes staring at nothing in particular, and embalm him.

The yaffle, when the leaves begin to fall, spends quite as much of his time on the ground, searching for various kinds of food, as he does in the trees, if not more. At this time the mimicry of the gay bird's plumage falls in so perfectly with the still green grass and the fading mosses which are thickly mixed up with it, that if he would but keep still-an impossibility, however-you could almost walk over him without seeing him. As to his crimson crest, that does not betray him, for so many brilliant fungi of various shades, from rich orange to deep crimson, spring up in his haunts where he goes emmet-hunting, that the fungi might easily be taken for the bird's crest as he squats, or the crest be mistaken for the fungi. 
Not only does the bird excavate for eggs in the ant-heaps, but he goes for the ants as well. I have seen two lumps of these industrious little insects, each one about the size of a filbert, bound up with a glutinous secretion, which the long tongue is lubricated with, and other matters as well, taken from the stomach of one fine cock in the fall season.

The woodpecker is fat, then. That they have been palmed off as delicious waders, when in a state of obesity, of course in a cooked state, I will not state directly, but I fear they have. To the fact that the beautiful creature has been shot and nailed up to the gable end of a dog-kennel, I can bear witness. A rare show is seen at times; for all the creatures that do not come under the heading of game get nailed up there, or their remains are left hanging; quite sufficient for the purpose of identification. I have heard him in the deer-parks, when the fawns were gambolling, and his voice may be heard above the grunting of the bucks and the clashing of their antlers in the fall of the year; on the bare hillside also, and down by the river, when he dipped down to drink, on wind-swept commons, and on railway embankments. 
The bird deserves protection, for he does, as "Larry Mackshale" once observed, "A rale thundren' power o' good by hammerin' things to pieces, if you plase." In fact, our old friend acts just in that same way by the trees as the rook and the jackdaw do by the cattle in keeping the vermin under. What insects and grubs can do in the way of harm to timber trees, is best known to those who have had practical experience of them in a business capacity; and this the yaffle from morning to night does his best to prevent.

The great spotted woodpecker, or, as it is sometimes locally called, wood-pie, or Frenchpie, may be briefly described, so far as its plumage is concerned, as a black and white bird with a crimson patch on the back of the head, and on the under tail coverts. The iris of this bird's eye is red, a marked distinction from that of the yaffle, which is, as we have mentioned, of a greyish-yellow. The wood-pie is not rare in the districts I roam over; but the magpie itself is not a greater adept in dodging tricks to avoid observation than this redcap performer of kettledrum solos. He does not drum quite so much as his small black and white relative, which we shall presently 
notice, but he does play up, and he plays well.

Old trees in the woods and parks-fallen timber that has been drawn from the woods ready for the timber carters-old Scotch fir clumps, and best of all, out-of-the-world old orchards, where the branches of the trees are never trimmed, and the moss-covered trunks are not lime-whited, are in favour with this active, shy bird. And yet at times, under the most favourable conditions, I have only caught a glint of the bird and his mate, and that after hours of patient watching in one of those old orchards; for in their noiseless fashion they will slip on one side, and around you, or they will, all the time that you are about. confine their attention to the tops of the trees.

This proceeding on their part conceals them from observation in the most effectual manner; creep and twist about as you will, there is nothing to be seen above the trunks of the fruit trees, which are so closely ranged, that the network of limbs and branches hides all.

Our short views of him whilst he is at work have been very close to houses and their inhabitants. Why a bird of such shy and retiring habits should come where men are at work in 
a garden, and proceed with his investigation of the trees with as much apparent confidence as one of the white-throats, is one of those contradictions so frequently seen in bird life, not to be accounted for in any way.

I venture to state, from the little that the wood-pie has permitted me to see of its movements in the course of years, that when it is pressed close to a moss and lichen-covered trunk, with its head on one side, and so low down in the shoulder feathers that not a vestige of the red cap can be seen, that any chance observer might pass within a yard of the bird and not see it. Not that the wood-pie confines itself to trees where the black, white, and grey mosses so perfectly mimic its own colouring; but when it does this, and especially if it has sighted you, the difficulty you will experience in observing "drummers" will be very considerable.

As regards the drum of the bird, which is heard more particularly in the pairing season, I wish to offer my opinion for what it is worth, formed as it has been from patient investigations, at all times of the year, in the woodland haunts of this creature.

One favourite haunt that I visit is a long line 
of decaying trees, luxuriant in foliage still, but only the wrecks of what they once were. Some of them are eighteen feet in girth, with huge dead limbs, barkless and bleached, showing out from the greenery. And high up over all, the pikes of the dead top branches show like bare poles. On these bare, bleak pikes, at different times of the day, and under certain conditions of weather, the bird drums; and I have heard that drum answered instantly half a mile away.

As you listen, with your ear close to the bare wood of one of these old forest giantsfor great patches of rugged bark have loosened and fallen years ago-the roll rattles down to your very feet. On a bright spring morning, when the air was fresh and sharp, but still, I have listened to them for hours; as a rule, if the weather was at all favourable, from half-past six up to ten o'clock. A bird that is only nine inches in length, or nine and a half, when on the top of a bare pike, seventy, or it may be eighty, feet above you, is a small object, but the glasses settle the matter. There he is, and the blows are delivered with such rapidity, that the head shows us a blur only. To use a very homely expression, the head of the bird appears to be in two 
places at once. There may be cracks and small holes, superficial ones, in the wood of those branch pikes; but they are not rotten just yet, they are as solid as cord wood. I have done the same thing as one of my woodland friends, when he was in doubt concerning any natural matter, used to do for a proof. He was a field naturalist, of a very practical nature, knowing all the creatures that were good to eat, where they lived, when they were out, and when they were at home. Not only that, he knew how to get them, if he thought fit.

"You know, dear boy," he would say, "it ain't the least use fancyin' as things is so, you must prove 'em. What's larnt fur nothin' is cheap, an' good for nothin'; but what you larns yerself, an' pays fur, is all right; you've paid fur it, dear boy, paid fur it, an' you knows the worth on it."

Our old acquaintance used to pay in coin of the realm when certain "powers that be" objected to some of his practical studies. "It was werry unkind of 'em, but he'd look over it," was his usual comment. To return to our feathered drummer ; all insects that live in decayed wood, either in grub form or in their perfect state, advance or recede, according to 
the weather, in the decayed fibres of the wood. When the weather is genial, they naturally draw as closely as they can get to the outer crust of decaying matter. Then the woodpecker's work is easy; he can stock and pick to his heart's content, now and again scuttling up to a top pike to drum, in the exuberance of content over a well-filled stomach, just to let his future mate know that he is doing exceedingly well.

But let the wind change to the east or northeast, and a change comes over the spirit of the scene, putting a stop to his playing. All his time is now fully occupied in working hard for a living, for the grubs have gone back as far as they can go, and the mature insects have crept under the loose bark. So strongly are all creatures affected by a sudden change from due south and south-west to east and northeast, that the whole range of woods and fields are for the time mute: with the exception of the storm-cock, not a bird is to be heard; but he sings through it all.

I have not seen the bird under notice visit the ground, as the yaffle will, in fruit orchards. Long lines of ants visit the plum and cherry trees, for the sake of the gum so liberally 
exuded from them. At the time when I had free range in them, pieces of pure gum, ranging from the size of a shilling to that of half-a-crown, were very common. Probably his corrective and stimulating diet of ants, which seems so very necessary to the members of his family, is procured from the trees; for if the bird had to go on the turf for them, he would show as conspicuously as a piece of printed paper.

In a state of captivity woodpeckers are most interesting and confiding creatures. It has been necessary to keep them in captivity in order to set at rest some of the myths of a certain class of wind-bag ornithologists. After observing the changes in the young birds, both male and female, as they advanced towards mature plumage, I can only say that the process is most curious and interesting; but want of space will not allow me to enter into details of a somewhat scientific nature.

Not that I care personally to see them, either in large cages or in aviaries, for no amount of care and of kindness can compensate for their want of space there. The raptores are not more out of their element than are woodpeckers in confinement.

The lesser black and white woodpecker in 
its general colouring is so much like its larger relative, that any slight details concerning that bird's plumage will not be necessary.

It is a small creature, barely six inches in length, but the noise it makes, when the first signs of spring begin to show, might proceed from a bird as large as the great black woodpecker.

This is the bird that gives those faultless side-drum rolls in such rapid fashion.

The air is fresh; in fact, it might be called a little keen, although the sun is well up and shining brightly; but you breathe fresh life every breath you take, the life air of this fresh springtime. A slight frost shows on the grass of the grazing park-lands we are passing through, just enough to let you see that "cuckoo weather" will not come for a week or so. It had been a dew for three parts of the night, changing towards morning to slight frost. Rooks and jackdaws are, when roosting for the night, very seriously inconvenienced by heavy dews, especially if a cold change comes.

On this bright morning some forty, or it may be fifty all told, have perched on the top branches of a dead tree that the sun is shining 
full upon, stretching out their wings, humping up their backs, and bluffing our their breast feathers - a lot of black, drenched, raggedlooking scarecrows. From the noise they are making one would fancy that they did not like their wetting, the croaks, barks, and gorbles from the lot of them make such a rare to-do.

A couple of hares are looping along the sandy part of the road, drying their feet; three more are sitting up on some old mole hillocks. Directly we have passed along they will come out on the road and join their companions; for they are sociable beings at the season when the little black and white drummer performs; and for a time they carry on high jinks.

Three rolls ring out in succession, with only a few seconds of pause between, and you hear the sound from them floating off into the distance. Then answering echoes ring out from the old oaks under the hills; and, close to us, the first performer drums again. It is exactly like two drummer boys signalling to each other with their side-drums.

Unless this handsome, nimble dwarf of a woodpecker visits fruit trees in gardens, he is very rarely to be seen, even by those who 
have plenty of time to look for him. When the little fellow visits gardens-and this he will do in populous country towns, not villages-he is sure to visit the plum and cherry trees. As the smallest patch of moss or fungi is never allowed to gather on choice trees, the bark is clean and bright. Light olive, with a tinge of slate colour here and there, gives the best idea of the colouring.

On this, when he is skimming about in all directions, the bird shows out like some handsome, quick-moving, tropical moth. The last one that I had was killed with a "pea rifle" almost close to my own door.

A sovereign will not place in your hand, if you require them particularly, either the greater or the lesser black and white woodpeckers, or their eggs; they are hard to circumvent, so far as the birds are concerned, and the eggs are still more difficult to handle.

A keen shot, well up in woodcraft, once had permission to range a fine avenue of beech trees for a specimen of the greater species. The bird was there right enough, for he not only heard it, but he saw it dodging about frequently; but it was three weeks before he got his bird. 
Some folks think that wild birds' eggs can be obtained as easily as fowls' from a hen roost, yet I have known a thirty-round ladder to be used, and a mallet and chisel, and then the woodpecker's eggs were not procured. I have had, in my time, the three British species, mature and immature, also their eggs ; but that was before the Bird Act came to the front, and our free ranges were wider than they are at present. If the exertions of those who see the creatures daily, or at least hear them call within a few yards from where they are working-and your own efforts thrown in-will not get them for you, rest assured that their wits are at least as keen, possibly a trifle keener, than those of the men who have done their best to outwit them.

Before leaving these three species of woodpeckers for their allies, I wish to state that only three times in forty years have I had a fair sight of the last two noticed; glimpses go for nothing. The common yaffle can be watched, not easily, but if you use very great caution; but the black and white ones, so far as my lengthened experience goes, in the midst of their favourite haunts defy observation. 
Two hours spent under one tree, hearing that drumming at intervals without catching sight of the bird, is quite enough at one time, and I have the credit of not missing much as a rule.

Their habits can be studied in captivity, I know; but they are artificial ones, to a very great degree formed by the force of circumstances, to which all captive birds so readily adapt themselves. Their breeding, or we will say their nesting, season is the only time when they lose their heads a little, and relax their vigilance-all very proper and excusable; for as one of our great poets has written, "Love will still be lord of all."

The nimble nuthatch, with his blue-grey back, black eye-streak, white throat, and orange-red breast, is, to say the least of him, a very pleasing bird to look at. But one can say more than that, for all his ways and means, in fact, all the bird's habits, are quite as pleasing as is his plumage. The wryneck, cuckoo, and swallow are said to be the three harbingers of spring. Yet the nuthatch is the first one to let folks know, by his loud liquid notes - for the happy creature fairly bubbles them out-that the spring is at hand, 
and that life is in the air. The laugh of the yaffle, when he raises his crest in salutation to his mate, is not more noticed than the fifelike bubbling of the nuthatch by those who live beneath the shadow of the trees.

This bird can be easily watched if you keep quiet; in fact, when not interfered with, it shows traits of a confiding nature. The woodpeckers may do all that we have seen this little sprite perform, but we have never seen a woodpecker skimming along under a branch back downwards, or coming down a tree head first, as the nuthatch does.

I like to hear him twit-twit-twit-twit ! and to see him scuffle along the bottom of the hedgerow, hunting for fallen nuts. The bird's note then is the ordinary one; the fifelike bubble I have noticed belongs to the early springtime alone.

Filberts, cobnuts, and walnuts have to be watched very closely in the gardens of large houses out in the country just when they are ripening off, or there will be a fine crop of nut-hulls instead of nuts. The shells are thin and the kernels large; not only that, but they are finely flavoured, so the rooks, yaffles, nuthatches, squirrels, and dormice leave their 
usual habitats and the hedge fruits, and come in the most stealthy manner for choice garden produce.

It might appear, judging from the large size and colour of the bird-simply black, with blue and purple reflections - to those that do not know better, to be a very easy feat to shoot a rook. So far as I am able to speak from experience, the man that can lie for a rook, and double him up clean, knows how to handle a gun, and keep out of sight with it. If you wish to shoot rooks, or try at it, you must be under the trees they visit before they reach them.

No tree that I know gives such quivering play of light and shade as the thick foliage of the walnut. You may know that at least a round dozen are in the tree at work, but peer about and crane your neck as much as you will, not one bird will you make out distinctly; for the flashes from their plumage, and the play of light and shade on it from the foliage, make a jumble of the whole. At last your chance does come; for just as you are about to press the trigger, on the offchance, at a moving form above you, the keen eyes of Tommy Rook catch the glint of the 
barrel, up he flaps with a gorbling wor-or er-or-work; but he gets the whole charge, fair under the wing, and comes crashing down through the leaves, to be made into a Bogey Rook, set on a long stick. The other black thieves clutter out, dropping the nuts in their fright; and they ring up in circles, higher and higher, until, so far as that particular tree is concerned, it will be free from rook visiting for a day or two. If the spread-eagled plunderer had, when living, acted like one of the more experienced patriarchs in the domestic economy of his particular rookery, he would not have been caught.

Our active friend the nuthatch rarely comes to grief in his garden raids, for he picks up the filberts and cobs from under the trees that the larger birds have dropped. Twit-twit twit, he cries, and off he goes with his nut, to fix it for breaking up in a crack of one of the posts that support some climbing plants on the lawn.

Any number of creatures could be shot, when on their plundering expeditions, if these were carried on away from houses; but they get so very close to them that you dare not shoot. Still they come to grief, artful as they are. 
Birds do not come in or about a garden anyhow ; as a rule, they have one way to come in by, and another by which they go out. It is at their place of exit that trouble waits for them, on the outer side of the garden wall. The yaffle generally gets off scot-free, but not always, for at times he loops up just over the top of the wall, only clearing it, and loops down with extreme rapidity on the other side-a most difficult and deceiving shot to take.

Knowing from experience that no shot will be taken over the lawn, our little nut-cracker goes that way. More than once I have seen nuthatches, wrynecks, and wagtails on a lawn at one time, with a cheeky weasel looking after them.

Very beautiful are the places we wander over, even in the whiteness and silence of the snow. But the cold bites hard, and folks suffer as they ever have, and will do, from the ills of life.

"You're up then, mother?" says my old friend, a woodman; "ah, well, I be glad fur tu see it; when I went off this marnin' yer rheumatiz wus about as much as ye culd put up with, I reckins." 
“Yes, father, I be up, and middlin' easy, fur Luce hev' been over an' got yer supper cooked, an' set the place tu rights a bit. You git yer snowy things off, an' settle down easy to yer supper."

"Ah, I will that; but tu see ye in yer chair easy like will do me as much good as what I'm goin' to hev'. This 'ere snow's thawin' away fast; an' in a loo place, mother, when the sun wus out, I heerd one o' them 'ere little nutcracker chaps a-tryin' tu tune up with his coortin' whistle; warmer weather's comin', an' you'll soon git better agin."

The wryneck, with its pencilled plumage, the grey cuckoo's courier in advance, will only be briefly noticed, as I have written of him elsewhere. Like the fern-owl, the bird reaches us from a foreign shore. Both are welcome visitors, one heralding the spring-for the wryneck shouts directly genial showers fallthe other the early summer, for the "heave jar" churs and chases his insect prey when settled weather, the first of summer, has really set in. From my earliest years, when I, was lifted up to see the bird sitting on her eggs, in some of the holes so numerous in the fruit trees of that old orchard so well known to me 
as a boy, I have been in close touch with the cuckoo's mate. It is a most interesting and gentle creature, one that ought to be protected in every way when it visits us. Not that it has suffered much, as some birds have; for there is some dim sentiment about this creature, or a superstition, that wrynecks are best left alone. In some places, the strange postures that the bird indulges in at times when procuring food have caused it to be regarded as somewhat uncanny by our rustics.

With the diminutive tree-creeper, curiously mottled with dark-brown, white, and yellowish brown, a bird well known to every country child, we close. Searching in the mouse-like fashion, very different to the dashing activity of the first four birds on our list, the small creature, in its unobtrusive manner, does its appointed work equally well.

If these birds were not about to clear timber from injurious insects, there would not be such glorious trees standing; for their searching investigations are carried on the whole year round, the dead of winter not excepted. From what I have seen, there is not much fear of their suffering from collectors, or from those who do not collect, but who perhaps require 
one in the flesh, at long intervals, for descriptive purposes. For if any birds have a double allowance of the instinct of self-preservation in their nature, the woodpeckers and their allies possess it.

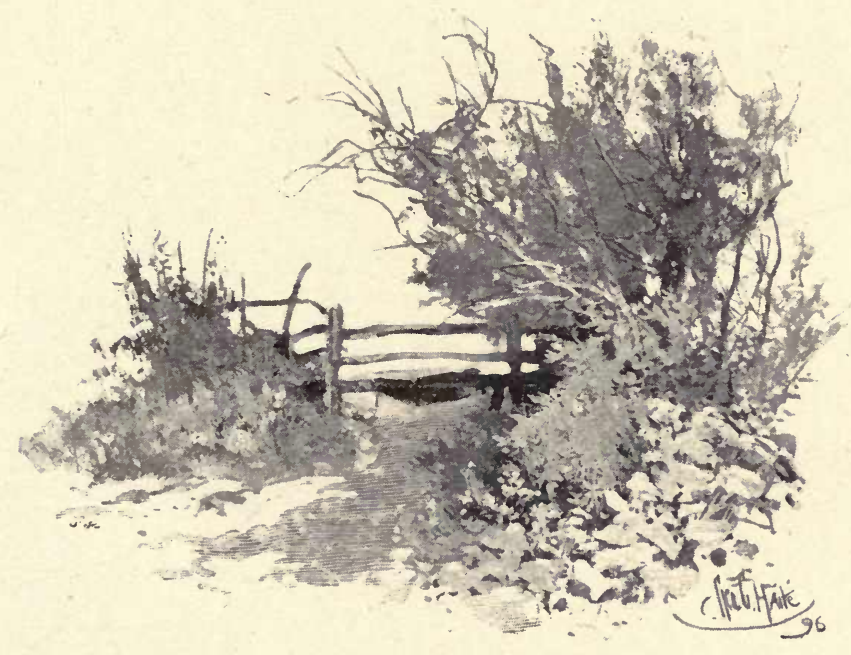



S U M M E R 



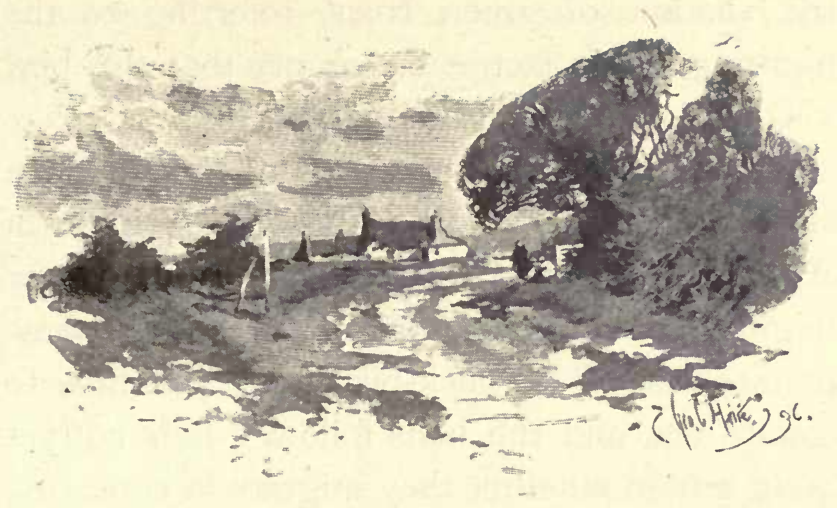

ROADSIDE SINGERS AND COVERT WARBLERS

I. ROADSIDE SINGERS

Авоve all other migrant songsters ranks the sober-plumaged bird which for so many generations has had a romantic reputation peculiarly his own, the nightingale, or "voice of the night." Merle, mavis, and plain-song cuckoo have all claimed a large amount of notice, but the nightingale is essentially the poet's favourite. There are beautiful legends and traditions, which are still believed in by those who live beneath 
the shadow of green trees, referring to the nightingale; in fact, each county that the bird visits has its own nightingale lore.

In the southern parts of England this fine singer may be seen first about the middle of April ; but this will depend on the weather, for migrants are very often about, yet do not show themselves. The cock-birds are the first to come over, and the hens follow. It is not yet quite settled whether they migrate in company, or come, so to speak, in driblets: my own opinion, formed from a close observation of their habits, is that they come anyhow, in very loose order. I do not assert this, but only give the opinion for what it is worth.

It is well known that on their first arrival they have been found close together on the shore in numbers, but they may have dropped down miles apart in the first instance. One bird will call to another for a long distance until they get in close company; and a certain district, or even a particular patch of saline vegetation, may be for a few hours all alive with certain birds, and these only; and then they are gone again, and not one will you find. "Birds of a feather flock together," and "any port in a storm" are very: old, but very true, 
sayings. Tired-out birds must rest for a time, and they do, when they can go no farther.

The nightingale is not sociable-that is, it does not mix with other birds of its kind; you will see it alone, as a rule, excepting when the young are out of the nest. Then the parents and their brood may be seen in company.

It is local, too, in its habitat, even in those districts that are favoured by it. A certain amount of warmth and moisture is necessary for its well-being. A copse-bank close to a hollow, under some hill with a southern aspect, suits him well: never a nightingale yet was heard to sing on, or we ought to have said over, sour ground. The full meaning of the term sour ground I cannot well explain in writing; but there are certain stretches of land where nothing will prosper, not even so-called vermin, and that is saying a great deal. And this unkind state of things extends even to the pools of water. Carp will live nearly anywhere but in these pools which are here and there ; in the sour district they are dwarfed, having heads like cod-fish.

You may hear our bird pouring his music out as you jog along the road; for he sings in 
the daytime, although many think that night is the only time when his voice is heard. You will hear him as much at one time as another, by day or by night; you can watch him singing, too; for secluded the bird may be, but no one can say that he is exactly shy.

His song is over for a time, and he has dropped down to feed. Just out of curiosity you look over the hedge at his haunt. A tiny rill from the meadows runs through that small copse, which is carpeted with blue-bells; and, yes, there is a cottage and garden, half hidden by the trees that shelter it.

Some main roads, although still kept in good order, are not much frequented. At one time the roads from London to Dover, Portsmouth, and Brighton, for instance, were travelled over day and night by coaches and her Majesty's mails ; you can go now for miles and miles without seeing more than your own shadow in front or by the side of you-in fact, the lonely way gets wearisome. Steam has altered matters in all directions for the better. Some of those roads through Sussex are as long, the natives say, as a "wet week," whatever that length may be. They certainly do run in front of you without a turn for a long, long way, and Sussex miles 


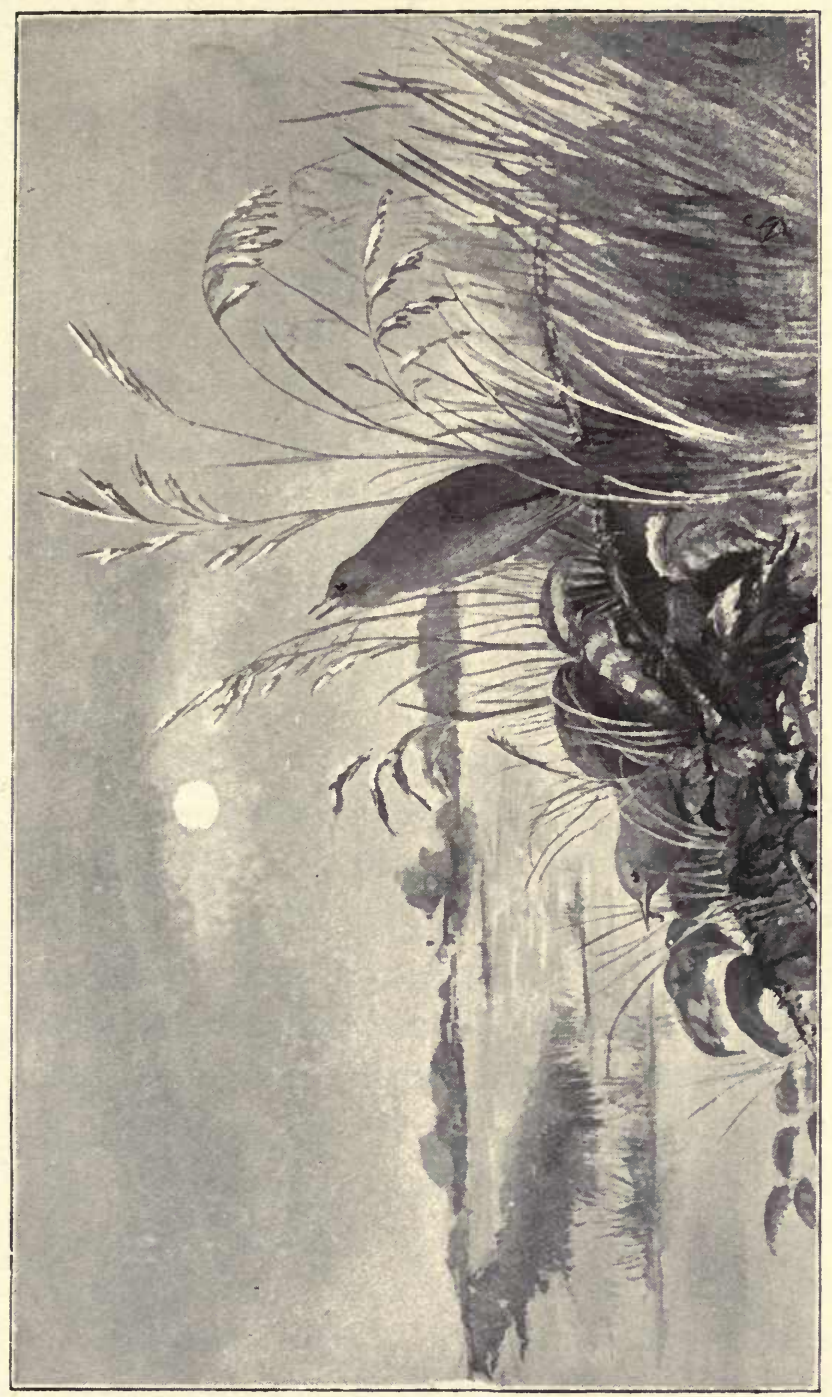

通 

even now, in some districts, are proverbial for good measure.

In this favoured woodland county I have found the bird under notice to be to a certain extent local, as it is elsewhere. There is a plaintiveness about the bird's song; it is not jubilant, like that of the merle or mavis. Often have I listened to that voice of the night in the heart of the woodlands, when others were sound asleep. No one, however, can call it a woodland bird-very few nightingales can claim that title in its full sense; but just on the borders, near to man, but not quite close to him, the singer will stay for a time.

It is a fact, now well known, that the bird is not so numerous in places well suited to it as it was a few years ago. Trapping for dealers has had nothing in the least to do with this; certain favoured spots and districts have for their very beauty been purchased and built on : setting on one side the natural beauty of the surroundings, the simple fact of the birds singing and nesting there was a guarantee that no sour ground was about. There is a vast amount to be learnt at times by taking heed of so-called trifles. If, in the course of necessary alterations, hedge-banks that have soil of 
a generous nature are cleared away, nothing can replace the insect life that once harboured there, and certain soft-billed birds must have certain insects.

Caged nightingales do not, as some think, require covering up to make them sing - that idea, like many more connected with kept birds, is simply ridiculous; but the amount of care and thought required, when they are kept as pets, to make birds of this kind happy, would hardly be credited. When winter comes, all kinds of expedients have to be resorted to, so that their food may in some measure resemble that which they would forage for and procure in a state of Nature; but it is well worth all the time spent to see the full-eyed bird ruffle himself out and cock his head on one side, before he comes down from his perch to take some dainty from your fingers. It is necessary for some naturalists to keep certain creatures for a time, in order to disprove ideas about them which have unfortunately got into print. Insects, small fruits, and berries compose his bill of fare in their seasons, and when our small fruits are ripe, the nightingale is ready to visit his winter quarters in other lands.

The blackcap, blackcapped-fauvet, or mock- 
nightingale, as it is sometimes called, is another singer by the roadside. This bird is shy to a degree, but he will sing near a road, a carriage-drive, or a path, warbling his rich notes out. These are not all his own, for he mimics other birds - at least, so far as my own hearing can be trusted. Thickly foliaged trees are preferred, where he can sit and sing to his heart's content, all unseen. If a clump of trees are on a lawn in front of some homestead, there you will hear the bird wail it out all day long-for, like the hedge-sparrow, the blackcap does sing at times in a wailing fashion; in fact, so close is the resemblance between these two birds at times that, if you are not able to see the bird that the song comes from, you could not tell one from the other, and this, no doubt, is a bit of the blackcap's mimicry. The bird's notes are loud, clear, and rapid; there is not a note of the blackbird's song in it all, but you may detect some very like those softer notes that the thrush gives out at times when the evening falls.

Country quiet may have much to do with impressions, so far as the strength of the song of birds in relation to the smallness of their bodies is concerned; but more than once 
I have stopped in astonishment at the volume of sound proceeding from the throat of a blackcap, just overhead, by the side of a road.

Like the song of Master Shufflewings (the hedge-sparrow), you hear no preparatory chirps or twiddles; out it rolls for the benefit of those who are privileged to hear it. The nightingale you may watch, but this bird is difficult to inspect with your glasses, for cover he will have when he sings.

In summer heat, when those restless, inquisitive, sharp-biting creatures, the fox-terriers, are for a short time fast asleep in the old courtyard, which is shaded over by plane and chestnut trees; where not even the clink from a stable-pail is heard to break the silence from under the cool green leaves-that rich song comes with startling distinctness.

His times for coming and going are the same as those of his larger relative. Some members of this species have been seen here in winter; but this is hardly worth notice, for many birds of the migrant class have been met with at different times in severe weather. Late broods, accidents, to which all birds are more or less liable, and mild winters, may 
account in some measure for these variations. But there is no infallible rule or reason to go by, for that large plover, the stone-curlew, a southern migrant certainly, has been shot to my knowledge in most severe weather. This bird was not injured in any way, and when it fell to the shot I had it.

The garden-warbler, a bird about the size of the whitethroat, but quite distinct from it, loves dearly to babble out his song close to the highroad. A low stone wall to divide the garden from the road, and one or two thick shrubs and bushes, are quite enough for him - in fact, all that he requires; and in one or other of them he will sit and sing to his mate from morning to night. If there is plenty of traffic on the road, all the better; the tramp of foot-passengers and the roll of wheels appear to excite him to fresh exertions, and he can hardly get it all out fast enough.

Other singers and warblers, belonging more or less to the same family, we might mention; but my purpose in this article has only been to direct attention, before fresh improvements cause them to flit far away, to these three famous roadside singers - the nightingale, the blackcap, and the garden warbler. 
Where large heaths and commons run continuously for miles, broken by ponds, pools, and wet plashes, well covered by thick old furze-coverts and thorn-bushes-both white and black-in such districts you may expect to see the "fuz-wren," the Dartford warbler, or, as it is sometimes called, the fire-eyed chat. As the bird was first noticed at Dartford, or near it, in the latter part of the seventeenth century, it has derived one of its names from that slight accident; but ornithological research from that date has extended in all directions, and at the present time, although from the small creature's habits it must be to a certain extent local, several places in Kent, Sussex, Surrey, and Hampshire are known to us where it may be called abundant, taking into consideration its hideling ways. The colouring of the bird is as quiet as its way of living; it is dark grey above, has a fan-shaped tail, is slightly edged with white on the outside feathers, the breast is warm chestnut, and the under parts are a dull white; and from the tip of its bill to the end of its tail it measures five 
inches. No wonder that the natives on the borders of Surrey have christened this bird the "fuz-wren." When his haunts are invaded, or the little fellow thinks that they are in danger of being so, his excitement is something to look at. He is all fuss and flutter; darting out of the furze and hanging over it, with his tail feathers spread out and his crest raised, he chatters out his Cha-che-che-che, Cha-cha-cheche-cha, as fast as he can get it out. Specimens of the birds I could have had very frequently, as well as their nests and eggs; but I do not collect or procure specimens of any wild creature for others, nor will I give the exact directions of the localities I wander over at times, for very good reasons.

Old locks and miles of water-meadows are close to the fuz-wren's haunts. All our water traffic is not yet done with, for sleepy barges still come from below, out of the west, into the river Wey.

It is a wild district, and to a great extent a lonely one: wild ducks and teals spring from bogs and waters now as they did in Gilbert White's time, although lines of railways cut through the country. With the exception of the red-deer-these are gone-wild life remains 
much as it was one hundred years ago; and some of the people are really, so far as their ideas run on certain subjects, which it is not quite expedient to mention, very like their forefathers.

Snipes and woodcocks nest round here as they have always done; but it was not to see these long-billed bog-runners that we roamed there lately from morning to night-for they breed close to my own home-but to watch, so far as it was possible to do it, the grey-backed, rufous-breasted Dartford warbler.

Entomologists would have rare finds in this district, for the fuz-wrens were busy; but the cover was, as one of the natives observed, "too rank tu git in." I quite agreed with him on that point. Natter-jack toads are to be seen travelling along at a rare rate; in fact, you might say at a run. There is as much difference between the movements of this striped natterjack and those of the common toad as there is between the paces of a cart-horse and a trotter.

Red vipers are too numerous here, if the truth must be told - the largest not more than fifteen inches long, and some only ten. You can take their measure when you have killed them, but you certainly will not do so before. 
They hiss and swish about quite near enough to be unpleasant, when you are looking for other creatures; their movements are remarkably rapid.

Insect plagues are, as might be expected, troublesome here-ticks, horse-flies, stouts, and midges; there are others, but the four mentioned are quite enough. In case our readers, or at least some of them, should come in contact with those we have indicated, let me suggest the remedies. If you find ticks fixed on you about the size of small peas, sometimes larger ones, it is useless to try and pull them away; that would be disastrous. Carry a small bottle, with a feather run through the cork, filled with olive-oil and paraffin in equal proportions. Pass the feather over their bodies if they fix on you, and they will drop off at once. Pull horse-flies in two-that is the only thing you can do with them; and after one experience of their torture you will kill every stout you can get at, which is easy enough. As to midges, don't go where they are if you can help it, only when necessity compels; but the mixture we have used will give relief in all cases. A flask of whisky will never be out of place or in the way. Practical natural observa- 
tions are charming, but the hard work entailed in making them is at times arduous. You may have the very best water-tight boots that can be made, but after hours of plashy tramping your feet get chilled: then take your socks or stockings off, moisten the feet of them with whisky, put them on again, and lace your boots up ; take a nip of the "creetur" as medicine, and off you go again all right. For provender, oatmeal biscuits are about the best you can carry : a square meal is not to be thought about before your day's work is done; and even if you required one, you could not get it where I have been recently, simply in order that I might look at a small dull-coloured bird. Moths of some size I know the furze-chat catches and kills; so do some other birds when the chance offers, for I have seen the wings of hawk-moths pulled from the bodies of their owners. What may be under those furze thickets in the shape of insect life, only the birds that live and shelter there know. Once, and once only, I crawled into one of these sanctuaries, and I have not the least desire to repeat the experiment; for what with one mishap and another things were too much for me.

In the drier parts of fuz-wren land that active 
reptile the smooth snake or coronella can be seen, looking, when it has freshly cast its skin, like a living band of smoked mother-ofpearl.

It will be long before any alterations of importance can, or will be made in this district, for directly you are out of Surrey you find the confines of a royal forest near you. The district above indicated is within a few miles of the river, where, as the Arthurian legend has it, the Lily Maid of Astolat, after her death, was carried upward on the flood.

The grasshopper-warbler, cricket-bird, or cricket-chirper haunts spots of a moister, and, if possible, more lonely nature than the one already described. On wide commons, all glistening with summer showers, when the rain has ceased, I have heard him reeling oft his song in some thick tangle that drooped over the water-filled wheel-ruts in the rough common road. There is something uncanny about it at times. All, or nearly all, the stock out at feed will be resting as if by one consent: with the exception of some patriarchal goose that is hanking out a warning to some straying gosling, all is as quiet as it can be; for birds do not always sing, atmospheric changes affecting them 
greatly. But our cricket-bird reels away contentedly enough.

- Just to refresh our memory, we cautiously pelt him out of his sanctuary, and then for a few moments we can see a bird about the size of the furze-wren, with a fan-shaped tail, greenish-brown with dark streaks on the upper part of it, of a lighter tint on the breast and under side, fussily darting here and there, as if it did not know where to pick out the thickest bit of tangled cover, within a few yards of it; for it never moves far away, pelt or thresh it out as you will.

How many times, in the course of long years, have I looked over the gate leading from one lonely farm into a main road near my present home !

There was the house, and the rambling old stackyard beyond, as quiet as a place could well be, when all work was over for the day. If it was dry, you might see one or two hares cross the road, or a partridge run towards the hedge, in passing into the fields beyond, but this would be about all, for it was what is called a wet lane. Wide ditches ran on either side of the green stripes that bordered the cart-way, and these were completely covered in by all 
the tangle that flourishes in such localities. Moor-hens, rails, and snipes used to run there; the farmer's son springed them; and that wet lane, with all its rough coarse tangle, was one of the favourite haunts of the "reeler."

Here, too, we have listened to the song of the woodlark, after the tree-pipit had done his trilling for the day, and have compared the notes of the fern-owl with those of the grasshopper-warbler near to us. One was like the rattle of a pike-winch going out at speed, the other was like the soft winding-up of a roachreel. Grasshopper- or cricket-like the note or trill has been called, but there is a wide difference, you will find, if each has been heard near to the other. Even the mole-cricket-little frisky pigs will half plough a moist meadow up in order to get these, if permitted, mole-crickets being to them what sweets are to children-has a different note to the reeler. The nest and eggs of this bird I saw two days before my article was commenced; they had been placed in the tangle of a very old orchard.

Insects form the principal food of this species, which in one respect differs from the Dartford warbler. The latter bird remains with us all the year round, the grasshopper-warbler is a 
migrant. In pursuit of the rarer birds-or we had better say the shyest, for birds are only rare comparatively speaking-I have lately been led into places of great beauty, quite away from all tracks or paths of any kind. Not that life is abundant in such places, for it is not so; indeed, all I have seen that might be called worth seeing, with very few exceptions, has come before me not far from the dwellingplaces of man.

Robin has often found me out in lonely places, where, sitting on the toe of my boots, he has shared the mid-day meal. Crouched up day after day in rough shelter, miles away from any house, he has been for the time being my only companion. How he found me out, or why he should have come and so quickly made friends with me, is a matter far beyond my conjecture.

How far back in the dim past the "ruddock" has been so intimately associated with man, who can tell? It must have been long before St. Guthlac, to Wilfrid's great wonder, made answer in the Fens of Crowland, "Know you not that he who hath led his life according to God's will, to him the wild beasts and the wild birds draw the more near." Pure minds have 
ever taken delight in trying to get in touch with the inmost heart of Nature. As the seasons come round, Robin adapts his ways of living himself to ways and means, and at all times, although in varying degree, he attaches himself to the society of man.

No cut and dried account of Robin could be tolerated by those who love him as a friend, and speak of him simply as "Robin Redbreast." To them it matters not to what family he is assigned by scientists; they only care to think of him as the courageous little bird which has been a favourite with Englishmen from time immemorial. Who can say to how far remote a date belongs our beautiful legend of the Babes in the Wood. The writings of old authors conclusively prove that the redbreast has been a bird of note from very early times. Shakespeare in "Cymbeline" says :

"With fairest flowers

While summer lasts, and I live here, Fidèle, I'll sweeten thy sad grave: thou shalt not lack The flower that's like thy face, pale primrose ; nor The azured hare-bell, like thy veins; no, nor The leaf of eglantine, whom not to slander, Out-sweetened not thy breath : the ruddock would, With charitable bill (O bill, sore-shaming 
Those rich-left heirs, that let their fathers lie

Without a monument!) bring thee all this ;

Yea, and furred moss besides, when flowers are none

To winter-ground thy corse."

To this day the bird is held free from harm ; no one dreams of such a crime as hurting Robin, for it is said that it is he who visits the lonely God's Acre, on and under the hills, when they are shrouded in snow, to sing over little children's graves.

It was a wild spot, out away from all hail, let what danger would come. All you could do was to fight hard, and make the best of it, if the worst came to you. The gorge I have in my mind's eye, when last I saw it, was partly choked up with tangle of a very rough description; and ragged Scotch firs lined the banks on either side of the hollow which led down the hills for a long way. The reason why I explored a bit up this place, lonely as it was, was that quite accidentally I had heard that a creature like a polecat, but larger, indeed (and if it was a polecat, it was the largest one that they had ever seen), frequented that worked-out ironstone hollow. As the two men, who had for a short time been felling timber near the hollow, were 
utter strangers to the neighbourhood, I simply listened and said nothing. I had reasons to think that a marten cat might be about, for one had been killed not many miles away; and therefore took counsel deep and weighty with Tommy, who was my stanch friend.

“Ah well! you take my advice, an' keep jist as fur frum that 'ere old holler as iver ye can. It's haunted-'taint a nateral sort of place. Old Shath-he's a bit o' a 'lation o' mine-told me when he was a young 'un, 'bout twenty like, as one marnin' airly 'twas menjous misty, and he heerd a lot o' hosses like, tramplin' down that ere place. Times an' agin hev he told me 'twas a wision o' sum sort. It waunt choked up then same as 'tis now."

As certain articles very often found their way over the district in spite of foggy weather, Tommy's relation, "Old Shath," might possibly have known more about the "wision he had heerd" than he cared to explain to his nephew.

"Ye mean goin' tu hide up ?"

"Yes; for a week, if there is a chance of seeing the creature."

“It's a warmint o' sum sort, thin. Now look here, don't you git foolin' an' looterin' about 
there in the middle o' the night, same as you does at times."

This I readily promised not to do; indeed, for reasons of my own I should certainly not have remained there after nightfall.

My watch was a fruitless one; I did not see the warmint, nor even a trace of it. It might have been there all the same, however.

However, Robin discovered me there; he was welcome, one need not say. His advances were of the most interesting and attractive nature; half shy, half confident, cocking his head first on one side then on the other, his full bright eyes glancing sharply about in all directions, until at last he had summed me up. Then he made friends.

Two centuries and a half ago one writer said of him :

"Call for the robin-redbreast and the wren, Since o'er shady groves they hover, And with leaves and flowers do cover The friendless bodies of unburied men."

If the swallows sweeping over the meres of Crowland visited St. Guthlac, we may be sure that the robins and the wrens were near at hand. 
Sometimes, friendly as he is, his visits are not always considered as omens of good. When he sits on the window-sill and taps on the glass for food to be put out for him, some of the cottagers are apt to wish he would not do so, as in their opinion any bird tapping on glass is not quite right somehow. This is nothing out of the way, however; for the sparrows that are regularly fed at my own house will tap on the glass for more, if they are hungrier than usual.

In the summer, although he is not far from man and his dwellings, he does not show himself very frequently, as he has a family to look after. But when the corn is carried, then by degrees he draws near for the winter; and in the morning, the afternoon, and the evening you can hear his song drawing nearer, day by day, until at last there is Robin, bold and bright as of old, waiting for you to repay him for his song.

From a technical point much might be written about him which, however, we feel confident our readers would not read. All this has been done by others. I would deal more with Robin as a feathered creature whose traditions for some inexplicable reason have 
been woven in with those of mankind, and our domestic life for ages. If some of those old manuscripts could be seen which were written and illuminated long ago, no doubt in many of those beautiful initial letters Robin might be seen at his kindly task of covering up some babe, a grave monk or a gentle sister looking on the while, as the little bird performs his deed of charity 
DOUBTFUL CHARACTERS: CROWS, MAGPIES, JAYS, AND SHRIKES

A PAIR of carrion crows would provide the most earnest observer with honest work of a by no means light character for a whole year; and then he would only see some of their deep wiles, not all : it is impossible to fathom all the depths of their nature. Not that the chance is likely to offer at the present time, for a price is on his head, every man's hand being against him; and the bird knows it. When he changes his quarters, the flight is high. Twice only I have noticed this within the last nine years; for in that time I have seen but three crows-one old solitary, and a pair. These were winging their way from a long wide range of upland downs to some dreary moors situated on the tops of distant hills.

Any one that has been used to hear crows croak is not likely to forget that note. Like 
most predacious birds, he is more or less a wanderer. At times a pair will settle, if it is possible for them to do so, but this is very rare now ; for the crow is, I think, above all other birds, the game preserver's aversion. Boldness, craft, and perseverance, with any amount of quiet courage thrown in, are judiciously blended in the crow; or, as the late Charles Waterton so often called him, and not without good reason, the warrior bird.

The changes in the treatment of all kinds of stock has, within the last fifty years, been a very great drawback to our sable searcher. Sheep at one time furnished him with provender; but these our readers must not for one moment picture as dainty little flocks of the most approved breeds, such as they may have been used to look at in their walks abroad. These latter are of the present time only.

Instead of the smaller fancy flocks, imagine thousands of light dots spread over the grazing marshes-all sheep, and miles of feeding for them. Then, as you travel on, still more sheep, until at last the eyes weary at the sight of them. Sheep are not favourites of mine: of both sheep and fish I have had more than 
enough. As a matter of course, a lot die off at times. If a murrain seized on any of the flocks, then the crows fairly revelled in the pest; indeed, when the murrain was about, the news soon spread in some mysterious manner to all the pairs of crows for a long distance that had up to that time-taking into consideration the inherent rascality of their nature-been trying to get for themselves a comparatively honest living. When the lambs were out, then they rejoiced again ; for sheep are the most helpless creatures at times, and if matters go a little bit crooked, even under the most favourable circumstances, they require looking after. And that lot of black watchers looked after them in their own fashion; to all intents and purposes they acted like ravens, only a little more so-any unpleasant details may be well spared.

Directly matters got better the company separated, leaving a clear field for the home pairs to work over.

Kept as a pet, the carrion crow is intelligent and amusing; but, like all the members of his family, he will, if the chance offers, steal any article that may take his fancy, and hide it in the most clever manner. If the members of 
the crow family did their thieving in a sort of happy-go-lucky fashion, matters would not be so serious. The worst of it is, they plan for it. Call it what you will-instinct or reason-the fact remains. If a crow catches sight of any trinket, no matter what, and is not able to get it at the time, a mental note is made, and the thief will come for it next day, or it may be a week afterwards. The hidingplace is picked out beforehand, so that if the bird is fortunate enough to get the coveted article, it is carried off and covered up before you could count forty.

No raven, crow, rook, or jackdaw should ever be at large in or about any house of mine, dear lover of birds though I am. As to the magpie, I would not suffer him for any price. Some birds are credited with far more cleverness than they really possess, others, again, are far more clever than they are supposed to be.

One good quality the crow has - that of rising early; but just to counteract this he goes to bed-to roost-late; for he is about some time after his dark form is no longer discernible in the woodland meadows. Like some others he can, I know, be seen now in 
places that have not yet passed under so-called improvements. But when it comes to this, that you are forced to go one hundred miles, or it may be more, to see some bird that at one time was so common that its very name was a byword, it has been well thinned off. And this is the case now with the crow.

The beautiful magpie, commonly called black and white, but one that in reality has the metallic hues of the Impeyan pheasant flashing from the dark portions of its plumage, was at one time so numerous as to be considered somewhat of a nuisance. If this was ever a fair indictment, the nuisance has now been nearly rooted out. As game was not preserved in the wild part of the country where I first watched his ways and means of living, my remarks on him and his surroundings will not bear in any way on that vexed question. All I can write about is from five years' observations of magpie ground extending a little over three miles: there must have been something in that line of country that perfectly suited these birds, for I have never seen them in such numbers in any other place, though I have sought for them.

It was a bleak bit of country; there was a 
gentle rise to the crest of a low hill that sloped down through hop gardens to the tide. The only things growing on the hill were thistles of a very stout and prickly nature, and low scrub thorns; nothing very inviting. On either side of this hill were shaws, which in southern counties are called copses, and thinly sprinkled about in these shaws were spindly ash trees. In the middle distance hop gardens and poles, hop oasts where the hops are dried, a few farmhouses, and the salt water beyond. On the tops of those consumptive-looking ash trees the magpies would sit and chatter, varying this amusement by flying to and fro from one side to the other, the distance between being certainly not more than a couple of hundred yards. As no restrictions existed as to where you might go, we explored a little and saw as much of the birds' proceedings as they would let us. Birds young and old, mice, frogs, snails, and beetles, as well as a plentiful supply of worms, must have been all that they could get there, and these needed a careful search.

From the position of the place, exposed as it was to all the fierce sea-gales, trees did not flourish luxuriantly, and the elms round the 
lonely upland farms looked thin and starved; they had gone through a struggle for existence. Now all these thinly foliaged trees suited the birds to perfection, for they could see all around and below them; and, if one ash tree stood by itself, a mere pole with a few branches towards the top, you would in the course of the day be sure to see a pair of magpies.

A relative who lived at one of the farms, when threshing was going on, always had his flint-locked Joe Manton, loaded in both barrels, in the barn close to his hand; but all the times I visited there, he never killed a single magpie; though it was not for want of trying. If young chicks or ducklings were about, they would interest themselves very much in all that might be going forward, in their own roundabout fashion. A couple would be seen-one on the top of that slim ash, and the other on one of the lowest branches-chattering and balancing their long tails as the breeze swayed the boughs, just as if they were only out for enjoyment. The topmost bird gives a low chatter, and joins her mate below; for some tiny ducklings are making their way out of the farmyard, close behind their mother. Down they drop, in between a couple of stacks 
that they are perfectly familiar with; no one is near. Along come the ducklings, all on the pipe; out rush the pair, and with one loud quack the duck hits one with her wings and knocks him over; but, quick as thought, the other has picked up one of the little pipers, and off they go, over the meadows on the crest of the hill to eat it. They could pick up common fare round about that district, but they visited the farms for luxuries, such as chicks and ducklings.

As pets they were not favourites; you would see twenty jackdaws to one magpie. The difficulty of getting at some of the nests may have had a little to do with this matter. The magpie's nest is a large one, formed, in the first place, of twigs and mud domed over, the inside lined with fine roots. As this dome-work is, as a rule, composed of all things that will tear your hands, if a nest is built in a tree that bends like a trout-rod before you have climbed half way up it, that nest had better be let alone; and so it generally is. As luxuries are not to be stolen, except at certain times, few and far between, the magpie and his mate have to fall back on what the fields, copses, and hedges provide for them. 
Gulls, rooks, and jackdaws follow the plough, but the magpie does not; he only forages in the fields. If there is one part of his plumage he cares for more than another, it is his beautiful tail; so, if the grass in the meadows is wet or damp, he holds it well up out of it. Those very accurate Dutch painters noticed this trait, and have painted the bird in this attitude when introduced into some of their unrivalled cattle pieces; just as he really is, far from game covers, getting his living, and taking care of himself by using all the wits of which the handsome fellow is owner.

The carrion crow might be called the lesser raven, for in all but size he is the very counterpart of his larger relative. He has a reputation all his own, one that no creature would wish to share, equal to that enjoyed by Odin's newsvendor, the raven.

The jay, a bright, active, and handsome bird, is as well known in the country as is the common house sparrow. Like that tiresome repeater of Chip-chip-chip-chisick-chisick ! he is about everywhere, although the hand of man has been, and is still, very much against him-from the game preserving point of view alone.

With country people and their children, in 
spite of all his fruit-stealing propensities, he is a favourite, like the "spadger"; and although he has had rough dues for years, he is well to the front yet. Children show their inherited common-sense by the way in which they treat their favourites, and when I lived with the Woodlanders they used to take me into their confidence. I often wish those happy days would come back again; but the times are changed, and the days of youth gone also.

"We want ye to hev a look at our young jay-birds ; they can't feed theirselves yit, so we got 'em in the bottom o' an old bee-skep. Dad says he'll knock us up a place fur 'em afore long, what they kin git about in, an' not rub the tails off, arter they got 'em. Jays is like mags ; they wants lots o' room to git about in."

Now, this is as it should be; but to see a dirty, ragged, tailless jay passing away its miserable life in a wicker cage made for a blackbird, is a sorry sight. As the master is, so will his dog be ; and a poor bird kept in miserable surroundings, or rather the scarecrow form of a bird, will run over all the objectionable sounds it may hear for the benefit of those passing by and living near it, and it actually seems to delight in its unbirdlike conversation. A 


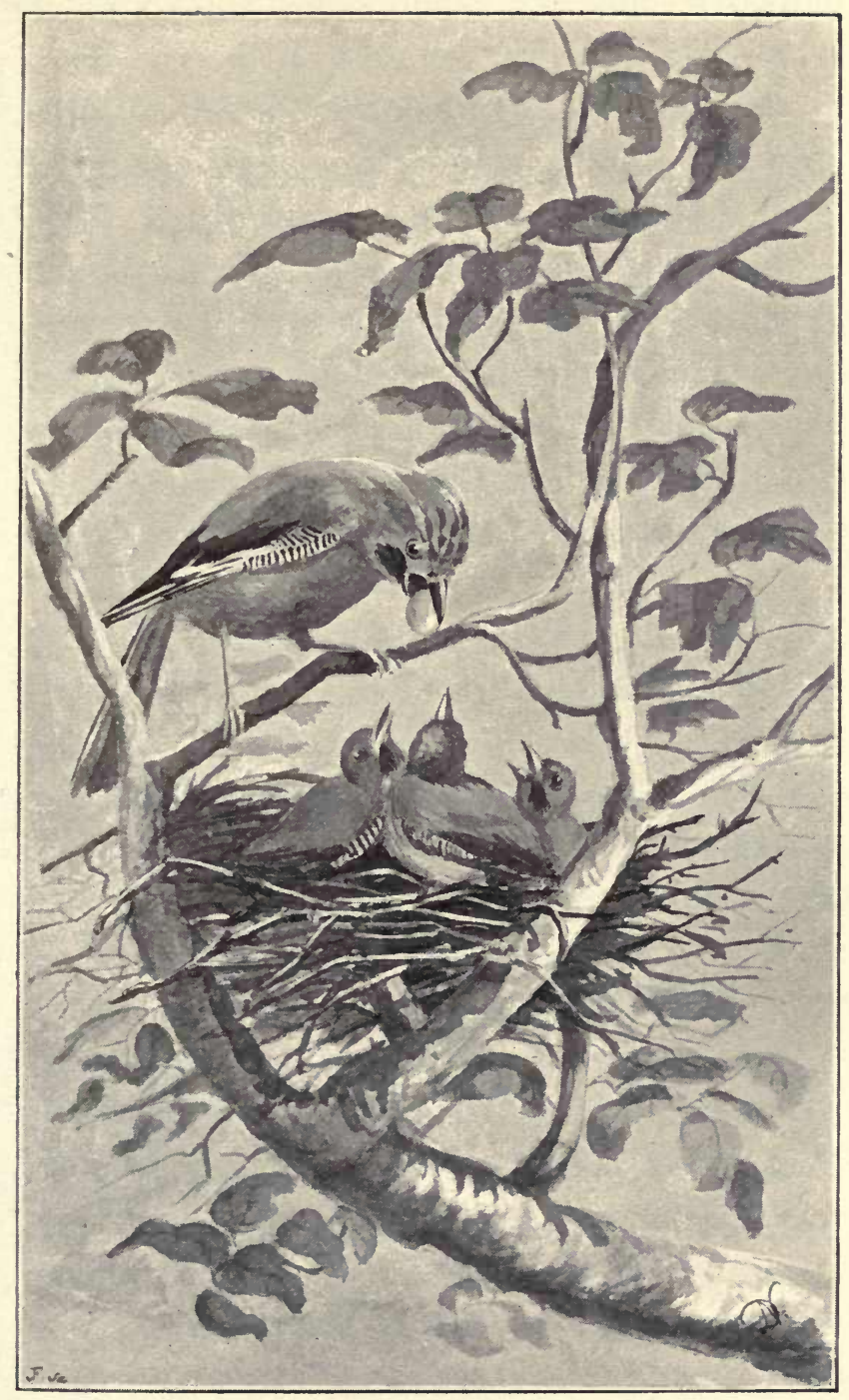

JAY AND YOUNG. 

magpie is far worse under the same wretched conditions. I have known a ragged black-andwhite feathered reprobate of a magpie talk to those who looked with pity on him, not only loudly, but in very strong terms indeed.

You will find members of the jay familywhole rows of them-nailed up on the gable of the keeper's tool-house or the dog kennel ; and if you are passing by and stop to look, should any one be about, you will be told that all that lot are jays-just as if you had never seen one in your life before.

Traps, poisoned eggs, rabbits, and the gun are all used for the bird's destruction, yet, in spite of all, he thrives and increases. The chief cause of this is the bird's astuteness - call it craft if you will; from the feather tips of his crest to the end of his fine dark tail, he is full of the instinct called self-preservation.

Now, many creatures are supposed to be killed right off and away: at least it is commonly supposed that such is the case. Nothing of the kind. Those who know more about their business than some would-be clever people, know and remember that "a man is not forced to hit a creature that he is ordered to shoot, unless he pleases." The art of miss- 
ing so as to defy detection is useful at times.

Alarm guns, in the covers at night, may go off with a bang-they do at times; but by day the jays do duty. No schoolboys ever shouted at any object of their dislike with greater vigour than do these birds at any intruder in their domains. Badger, fox, polecat, stoat, weazel, or a strayed ferret-all serve to excite their squawkings.

Just for the sake of experiment, try to slip into a covert for a dozen yards without being noticed, and you will hear nothing but squawksquawk-squawk. The birds slip round you in all directions without your seeing a single one. Directly a keeper hears the real alarm-notes of a jay, he knows that some kind of mischief is afoot. The now rarely-heard, fussy, chiding chatter of the magpie tells the same tale.

We are told that he kills lots of things, and so he does, and some, too, that can be well spared. He steals fruit, and devours marrow-fats; but so do hawfinches. He also steals eggs, taps them, eats the contents, and leaves the shellsrather a black record all this; but as crows, rooks, and the jackdaws, not to mention stoats, weazels, hedgehogs, and rats, all do the same 
thing when the chance ofters, the jay must be let off lightly, poor fellow. Worst crime of all, he kills young chicks. But what business has any decent hen to wander out into the fields and to lay in the hedge, as some of these fowls will? Guinea-fowls are as bad-they are a perfect nuisance in that way. When the chicks are out, they are here, there, and everywhere, in bounds, and out of bounds, all over the place.

Is it to be wondered at, then, if one or two of the little mites get picked up? though not many come to grief; for a hen or a "comeback," as the guinea-fowl is called, will show fight in the most determined manner in defence of their young broods. We sometimes see one of the large old-fashioned brown hens behave more like a bird of prey, for a time, than a barndoor fowl when her chicks are in danger.

It often appears to me that matters are a little one-sided just at present ; and it is unfortunate that those who know the least about wild life seem to have the most to say. If the jay did one quarter of the mischief he is credited with, he would surely have been exterminated long ago.

Like the fox, the bird is another scapegoat. If one falls to a shot it is generally a snap-shot, 
like shooting at a rabbit. The jay knows his flight to be weak, and that is the reason of all his stealthy manœuvring. As a check to the creeping and crawling denizens of the hedges, he deserves some amount of consideration; for one of his good qualities is that he is a clever mouse hunter, and he fulfils the office of tree planter. Acorns are the favourite food of this bird in the fall; so very partial is he to them, that they are stored. The jay stocks them away for future use in hard times. Retentive as his memory is, one or two of his little earth-stores get forgotten, and then young oaks shoot up.

You will often hear jays all about you without seeing one, but you can soon make them show up, if game are not hatching out in the coverts; for in that case you would not be allowed to enter them. If the coast is clear, walk rapidly up one of the narrow ridges and down another, brushing the stems and twigs as you go; then cut off in another direction and back again; and before they have had time to sneak up and find out where the noise comes from, they hear it in another place. They then get bewildered, and they clutter up over the trees like so many feathered lunatics, squawking. 
When pairing-time draws near, the jay might be called the dandy of the oaks ; for he shows off finely, as he raises his crest, and shows his bright wings and fine tail to the very best advantage, for his mate's admiration.

But even at this season he is wary, and if it is courting time he does not part with his wits, as some other creatures do. Just tread on a dead stick, or let him sight you, and with a squawk he is off.

First on the list of shrikes comes the Great Shrike. If you have the good fortune to meet with this bird, it will claim all your attention during the very limited time it will allow itself to be watched, for it is suspicious of danger to a high degree.

About the size of a fieldfare, but more strongly built, its plumage of grey and white, patched with black, makes it a conspicuous object, as it darts along or perches on the top of the twigs of some old hedgerow. It is known by various names, according to the districts in which it has been found. One of them is the mountain magpie, and at the first sight that is exactly what any ordinary observer would take it to be-a small magpie. Before the fine old hedges, those ancient bulwarks of the fields and meadows, 
were cut down and their roots grubbed up, I used at times, although not very often, to find the birds somewhere about them, if I carefully looked for him in the right seasons, autumn and winter; but such chances of observation are the exception, and not the rule. The finest bird which I have ever seen of this species, a male in full plumage, was hunting along a very thick and high old hedge one morning in July i 854 . Certain flight-lines are followed by a certain class of birds, even although the inducement, that at one time caused them to follow those lines, may have ceased to exist.

This is the case with the great shrike, for one was seen in the same place to which I have above referred in the year i 89I. Three, or it may be four, dead ones have been shown me in the course of the last seven years; and all of these had been shot in a sort of "No man's land" district, where old orchards still existed. The trees and their branches were moss-covered, but for all that they had rare crops, and the hedges that surrounded them were even older than they were themselves.

There is a row in the hedge, as if all the birds in and about it had got some particularly important grievance to settle. Then 
you hear a noise, as if some one were clipping the hedge with a large pair of shears. These sounds proceed from our shrike, who is on the hunt, mobbed, as he goes along with his very wagtail-like flight, by all the birds in his vicinity. Now he shows on the top shoot of a wild plum, and, so far as his position goes, it is like that of a small hawk. Up he shoots, quivers his wings for a few moments exactly like the "wind-fanner" kestrel, drops his legs and darts down. He has certainly made a capture, for faint peepings are heard; presently up he shoots to his perch again with his quarry, a hedge-sparrow. This example to the other small birds about, which have been so noisy, is as a rule quite sufficient for a time. Birds, mice, frogs, lizards, and other small things supply the larder of this feathered hunter of the hedges.

I have seen young birds and a few insects spitted on thorn bushes; but I am not able to state personally whether this had been done by shrikes or not, as I have never seen them doing it. This admission, however, only applies to my own observations, and does not in the least imply discredit on the statements made by other observers. 
In my wanderings up and down, noticing trifles, I have seen the woodland youngsters stick all sorts of what they consider objectionable creatures, after killing them, on thorns and in forks and clefts of trees and bushes. “ Jist as a bit o' a warnin' like to t'others as was about"; that was their way of gibbeting offenders.

Year by year this really fine-looking bird retires from the area of the so-called improved system of agriculture. Changes affect its wellbeing as a migrant, and in my own immediate neighbourhood the great shrike has almost ceased to visit.

Chack-chack-chack-chack-chack! This is the notice the Red-backed Shrike, or, as he is commonly called, the butcher-bird, gives out to let you know he is here again. In size he approaches the common corn-bunting, which, by the way, is wrongly named, for at the present time if I were offered five pounds for one of these birds I should not know where to procure it. So much for one so-called common bird. Now the butcher-bird really is common, not to the degree the sparrow is, but pairs of these birds may be met with, as you travel along in all places which are suitable to 
their requirements. In all his actions and in his general behaviour he is like his larger relative, with this difference, that in some of its ways he is almost as familiar as the robin: you can watch all its actions without any trouble. The smart little fellow commands attention, and well does he deserve it; he challenges it with "chack"! The nest is very like that of the missel-thrush, and as a rule it is easily discovered ; in fact, when their young are well out, they will let you know where it is by their scolding chatter.

Although the butcher-bird makes a most interesting pet, its nature being bold and fearless, I have never seen one single bird of this species domesticated by country people; nay, more than that, when I have expressed a wish for a nest of young butcher-birdsthis was before the Bird Protection Act was in force-somehow or other I never got them. There was the same aversion to meddling with jack-bakers, as they were called by those whom I asked to get them for me, as there is in some parts of Ireland at the present time to killing a wild swan. Something, it is believed, will surely happen afterwards. Of course I could have got them 
myself, but I refrained from doing so, out of respect for the prejudices of the country folk.

One of the most repulsive insects known to me is the long, black-bodied, strong-jawed beetle, commonly known as the cock-tail, or devil's coach-horse. It is a hideous creature; and if it were a thousand times as large as it is, it would be one of the most horrible presentments of the principle of evil possible to imagine. No matter where you may fall in with it, the vicious propensities of this beetle show at once. It stands still in front of you, it opens its jaws and cocks its tail. If you pick it up, and it bites you, which it will certainly try to do, a poisoned finger may be the result; for it is a carrion feeder. The feeling of horror which it inspires, I can assure my readers, is one which is shared by all classes, and not without reason. Fortunately it is a favourite morsel for our butcher-bird, being, as I well know, one of his luxuries, which he hunts for in the most persevering manner. That is one of the reasons why he is respected by the rustic population; they will tell you that he kills "old Cockyhoop's coach-hosses."

It is a most amusing sight to see a lot of young butcher-birds turn out of the nest, if 
alarmed just before they are quite ready to fly. You may have quite accidentally forced your way through or into the bush where the. nest is, and then what a racket besets your ears all at once! The old birds are round you, scolding their loudest; then they are in and about the nest, helping the young ones out of it. After that all is quiet, for the lot has slipped away for a time. Presently, if you keep quite still, you will hear close to you a very contented "chack—chack—chack." Not only do I like the bird for his own sake, but also for the pleasing pictures with which he has been for years so intimately associated,pictures where old farms stand just off the lonely country roads, with their slips of orchards. in front of them, looking like what they really are, genuine remnants of the past. There, on the gnarled and twisted limbs, bowed down by sheer old age, so that for some part of their length they lie hidden in the grass, you may see the red-backed shrike and his mate sitting and watching the grass beneath them for their prey.

A wide, open common, tenanted by rough ponies and their colts, with the scattered sheep. in no better case ; and, just to break the mono- 
tony a little, some ragged-hipped cows, with their bells; a blue sky without a vestige of cloud overhead; and an air so hot, that you can hear the seed-vessels of the furze pop and snap all around you. There you will see our friend perched on some bush close to the main road, watching for lizards or beetles, which delight to bask or to run about on its heated surface. When on the wing, the tail is kept straight out, so that it looks like one feather, and is very similar to that of the longtailed tit.

There are two rare shrikes which visit us just sufficiently often to be classed as British birds. One of them, intermediate in size between those shrikes which I have described, is the lesser grey-shrike. A pair of this species visited my own immediate neighbourhood in the latter part of June I886, but they were far too cautious to let any one get near them to shoot; and as the spot they pitched on for a couple of days was a worked-out chalk-pit, on private property, they did not come to grief.

The woodchat-shrike, which is similar in size and build to the butcher-bird, may be considered as one of the rarest of the shrike 
family that visit us from time to time. His range is a fairly wide one, extending from Italy, France, Switzerland, and Germany to the Cape of Good Hope. His general habits are like those of the species already described. 


\section{$\mathrm{V}$ \\ PIKE, PERCH, BREAM, AND ROACH}

Where a few years ago one man only fished, fifty, or it may be a hundred, are now seeking for sport. It is a fact frequently noticed that certain creatures are gun-shy, and it is equally well known, and very much to be regretted, that all the pike and perch worth catching are in many waters line-shy. Pike so called, fish that are in point of fact simply inexperienced young jacks that ought never to be fished for, are, however, basketed in numbers; and the result is, that the small fry, not having natural enemies enough to thin off their numbers, increase to such a degree that the large pike are not obliged to hunt for them, and simply snap what they require, as the shoals swim by their hovers. I recently saw one of these finny cannibals feed five times without moving the distance of three yards.

It may be bad taste, but personally I would 
prefer a pike to a trout any day for sport or for eating. In certain waters the different traits of pike are as well known as those of the anglers who fish for them ; and the method for their capture in one place will not do for another, as everything depends on the particular locality. Pond pike, unless a stream runs through the water, I do not care about; but if the run or runs, which supply water to the pond, be all right, you are likely, if only you can obtain permission to fish there, to get something that is really worth the trouble of carrying home. Leave is, however, now thought to be so great a favour that in some places no angler of independent spirit would dream of laying himself under the fisher's obligation. Most fearful and wonderful are the "consnaptions," as he calls his contrivances, by which a fisher, whom I well know, endeavours to lure the wily pike to sudden death, and sometimes his " consnaptions" prove of little avail. Where waters are stocked for the express purpose of fishing them, pike are so numerous that they will take nearly any bait that is offered, but this they will not do where they have free range. If at certain times a ferocious fish, the pike is never a stupid one; and any little novelty, something that he 
has not seen before, will rouse his interest, when roach, dace, and bleak cannot tempt him. Put the string of your bait-case round a stump, and sink it in the water; you know that he is there but declines to feed. But ask the boy at the mill to get you a young half-fledged sparrow out of the cart-shed thatch, and to kill it for you; then take off your float, if you have been using one, and hooking your dead sparrow in the middle of his back, let him go gently. There he goes, his little stubby wings out and his legs apart, just as if he had tumbled out of a nest and was sinking head downwards. Look! it is out of sight now ; and away shoots the line-you have your fish right enough, and he has got his sparrow. In fair all-round fishing, if one, or, for the matter of that, if every one of these different baits fail, try something which fish do not see very often, even if it be only a mouse. Those artificial monsters called pikeflies will answer for a time, if used under favourable conditions; but the so-called fly will have to be changed as soon as its novelty has worn off a bit. All that a pike-fly hooks will not be landed, and after a time the intended victims get to know the look of the feathery fraud, and, refusing to be deceived, will have none of it. The gentle 
PIKE, PERCH, BREAM, AND ROACH 135

art of angling is a theme which allows ample latitude of opinion, and people's opinions do vary on that subject very much; but in one matter all the old-fashioned pike-fishers of my acquaintance agree : and that is, that if they knew that a large fish of that kind lay in, or haunted a certain place, they would try for him with a large bait; and this, indeed, is but reasonable, for as a rule large fish do not care for small fry. Pools and shallows in some river which has clear water and a moderate flow suit the pike best, for gudgeon and minnows also haunt the shallows in shoals. In a stretch of water, which is about half a mile long, I have seen a dozen good fish close to the surface when the sun was shining; but it was useless to try for any of them during the day, throughout the months of July and August, as they were wont to feed early in the morning and late in the evening on the shallows, in about a foot of water. One very handsome pike had, it seems, before his haunts were discovered, been feeding more like a trout than like a member of his own family. For months he had fed at the end of a shallow, which ran from a mill into a hole just large enough for him to hide in, and he never moved out of it; indeed, he would 
have found difficulty in getting out, as some bank planking had been placed just below his hover, which fenced him in. One of the miller's men chanced to go to that hole for a pail of water for his horses, and caught sight of him. Then he was soon out of it, for some very good trout,--a couple of brace, for certain,- - were in the water just above him. Pure water, plenty of good feed, roach, small eels, dace, and minnows had all gone into his capacious mouth, whenever they chanced to travel his way; and not having had to range for food, he was a thick fish, a real beauty, spotted and barred to perfection.

Large pike are all very well as trophies of the angler's skill or of his luck, as the case may be; but they are of no use for table purposes. Five to eight pounds is the weight at which to take them ; and, when they are in good condition, few would wish to eat better fish. I would not take a pike from some waters I know, because when ponds or lakes have been left for years without being cleaned out they get foul-that is to say, well stocked with frogs, efts, and leeches; and when pike indulge in these luxuries of diet, no one hankers after eating them. 
As the water is, so is the play of the fish when he is hooked. Find out if you can for yourself, and not from other people, where a good fish lies, by the side of some flag-fringed, tumbling bay, just clear of the force of water from the sluices. The water leaps and sparkles on its way down-stream, until it meets a bend in the bank of the pool, which causes it to swerve round and follow the line of flags at the side of it. Slowly then it comes along, bearing with it light foam bells, and bits of broken sedge wrack, to pass once more into the main current from the sluice. Now get your tackle ready; the simpler it is the better it will be. Let your hook be a good single one; whip on the finest and strongest gimp you can procure. See that the joints of your pike-rod are firmly fixed, and that your ringjoints are true. From your bait-kettle take a bright silvery dace, eight or nine inches long, fresh from off the shallows below the mill, insert the hook at the root of the bait's back fin, and all is now ready for action. Drop it in, a few yards below your standing-place behind the fringe of flags, and let the sweep of the back-current bring your silvery lure past you. On it travels, until your olive-green 
float, with a small ring of pure white on its top, not larger than a button, halts for a few seconds in a bit of slack water which is bayed in by one of the projecting sluice-piers; then down it goes, and keeps down for some minutes-a couple of minutes it may be-before the float comes to the surface again, not far from where it disappeared. Under it goes once more, but not out of sight; then up it comes, and you gather in your slack line. If you have any, see that your winch, or reel, is all right, free from a "kink up" and a smash; and then strike. Not that striking is necessary; for he has pouched and hooked himself, but simply to let Esox lucius know that there is something at your end of the line as well as at his own.

Out rushes the fish through the broken water from the sluice-gates, and for a time he sucks in the slack, on the other side of the run; but the strain on the line, caused by the current, frets him, and presently he is once more on the move, returning in a sweep to where you first dropped your dace in for him. Now the float shows for a moment in front of you; give him the butt, just to see what he is like, and whether he is ready for grassing. Not just yet 
at any rate, for with a rush out goes the line, not into the rush of the sluice this time. Wind up, turn his head on to the current, and drown him if you can. This movement on your part is objected to, and you have the pleasure of seeing your fish, springing clear from the water, turn on its side-a sure sign that you can begin to take liberties with it. Down with your rod! You can trust your tackle and bring your fish in, and land him by judicious hand-over-hand hauling. In the present age, when the most ordinary matters are conducted on strictly scientific principles, this method will probably be despised as too simple by a certain class of modern anglers, who will think it a mere boy's way of fishing for pike in a sluice-pool. Well, the plan is extremely simple, childishly simple in fact, but it has often proved very successful. Costly tackle will not ensure that you will catch any fish. Although I do not fish now, some who remember me when I did still do a little that way, will from time to time send me a good fish they have caught, to paint from. I have recently had the pleasure of painting a perch that weighed, fresh from the water, one pound and three-quarters, and for 
colouring and condition it was as a perfect peacock among fish.

It seems to my memory but a short time since three or four schoolboys made a certain willow-shaded brook their only fishing-place; our leisure time, morning, noon, and night, at least until bed-time, was passed in healthy amusement during the fishing seasons; four confirmed young fishers, each fishing, I remember, in his own way. Our rods were cut, of course, from the pollard willows. Then, too, the manœuvring of it all; the slipping behind the trees opposite the perch holes, to find out if they were at home. For we did not trust to chance work, and the question was soon settled, for if they were at home no roach could wriggle from under a stone on the shallows without a perch making a dash for him.

We all fished with worms, but each lad had his pet theory - it was nothing more-as to the best kind of worms for the job in hand. The oldest of the lot had, by parting with some of his very limited pocket-money, bribed another boy to get him some of his father's fishingworms-brandlings. These had been well scoured-that is, kept in damp moss thoroughly washed, and with a couple of spoonsful of new 
PIKE, PERCH, BREAM, AND ROACH I4I

milk added to it. I want my readers to bear in mind that the moss was washed and squeezed every morning, and that fresh milk was then added to it.

The boy who had surreptitiously borrowed his father's worms so impressed our leader with an account of their wonderful powers in catching fish, owing to the way they had been coddled up, that the enthusiastic angler could hardly sleep at night for thinking of the marvellous creatures. Have some of those worms he must, even if he made himself bankrupt for it, which he did for one week, at least, by spending fourpence, which was the whole of his pocket-money; being further impelled to this extravagance by the worm-borrower's gentle insinuation that "only the big 'uns would snap those milk-sucking worms."

But when it was found that those who had dug their worms out of the gardens ten minutes before, and put them in a small flower-pot with some dirt — earth, we should have said — for them to hide in, taking them just as the spade turned them up-red worms, or lobs, no matter which - had better sport, and that the lobs certainly caught by far the largest perch, - that fourpence was considered money thrown away. So much 
was the expenditure regretted, that mutual explanations, ending in a fight between the parties most interested, was the result. As the worm merchant afterwards appeared at the family abode with various marks on his face, explanations were not only needed, but were demanded, and those that were offered did not meet with acceptance. Some thought prompted the stern parent to examine his precious store of worms, and the result was, that his young son was persuaded to accept a dose of "ash-ile," liberal in quantity, and of the very best quality. Things in those far-off days worked, somehow, remarkably well.

Regarding those precious worms, the brandlings, the method of preparing them for fishing is not a mere fad or fancy. I have pursued exactly the same course with them, and got them up into fine condition. They are attractive from their colouring, which is arranged in alternate rings of red and yellow; but I do not place them before common worms, for this reason: the brandling is only to be found in decayed matter, such as old manure-heaps, and places of similar nature. When fish get worms in the common course of nature, they have been washed into the waters from the water-furrows 
of the lands above them, often in very fair quantities, and three parts of them are sure to be the large worms called lobs.

As a live bait for perch, under the present order of things, the minnow takes first place. If I were to have my choice, and I knew that large fish were in the swim, and that the baitkettle had some stone loaches in it, I should pick out the largest of these for my lure. You can at times see in clear water how fish feed, and what they are just then feeding on. As perch are bold fish, and as a rule bold biters, this has not been difficult for me to do. With his green back, barred, zebra-like, with thick lines of black, his yellow-tinted side and white belly, the whole effect touched up, so to speak, by some of his crimson and vermillion-tinted fins, the perch is indeed a beauty.

"He that hath a bream in his pond is able to bid his friend welcome," said Izaak Walton.

Bream and roach are great favourites with a certain class of anglers; in fact, a Norfolk bream fisher and a River Sea roacher have been as much written and talked about as any class of the angling community.

For years the Broads have been famous for their bream; but there is not the least necessity 
for Londoners to go that distance for the fish, as they are very numerous, and of large size, nearer London. The Thames at Weybridge, the Medway, and the Mole are noted for them, the last-named river particularly so. Any quiet flow of water suits the carp-like habits of the bream; depth of swim, where he can range leisurely to and fro, is to him a necessity, and all this and more is to be found in the river Mole.

"How long have you fished here for bream?" I lately asked a man, whom I met in a secluded nook of the river-side.

"Well now, let me see; I reckins off an' on like fur fifteen years. You knows things is altered; well, when the notice-boards was put up sayin' as all them as wanted tu fish would hev tu pay for it, I waunt a-goin' tu run my head agin a brick wall; fishin' is like wittles an' drink tu me. So I goes tu the one as has tu du with it, an' I puts it straight. 'I can't affoord much,' I says, 'fur I ain't got it, but I do want tu fish.' An' he looks me over, up an' down, an' then he says, 'As I'd come tu him like that, he'd only charge me a'-ahwait a bit, let me see-a nom-sumthin."

“A nominal sum?” I suggested. 
"That's it, year in an' year out. An' yit sum reckined as he was a wusser to deal with. Sum folks is like cats, you'd better not stroke 'em wrong way. Now you'd never credit the sorts o' people as ferrits me out at times, an' wants tu cum fishin' along o' me. They finds out where Old Will lives somehow, an' sum on 'em is all right, an' acts right, an' sum on 'em don't ; they don't know how. One on 'em asked me more than I knowed, a lot; leastways. more 'an I meant tu tell him. An' he'd got a. big flask that he baited himself with middlin', but he never offered me none. If they think as they're goin' tu be told an' showed how tu kitch bream fur nothin', well, they wunt kitch 'em. He didn't kitch one; I took good care of that."

Some I know eat bream, and consider them equal to flounders; they are prepared as follows:- The fish are scaled, cleaned, sprinkled with salt, hung up to dry all night, and fried in the morning. I do not, however, think those who praised them could have eaten flounders. fresh from the tide. When bream are offered to me they are declined with thanks.

A fishing-rod is, like a gun, very good company; the sport is one which keeps your eyes 
wide open; I have seen people fall asleep over many jobs, but I have not yet seen any angler go to sleep with a rod in his hand.

Bream, as I have said before, haunt quiet depths of the river. Half-a-mile's saunter along the river's side brings us to the end of the meadows, where a stout oak-post-and-rail fence keeps the cattle from breaking into a fine orchard; and this particular spot is the best place in all the river for bream, down to where it flows into the Thames. Great oaks dot the opposite banks; and one large limb of a fallen oak, that has been submerged for years, rises just above the surface, affording a lair for a very heavy pike, on whose account no one ever dreams of wetting a line close to it, as it is well known that at different times four good bream have been torn off the hooks by the greedy monster, just as they were being landed. One of my angling friends has expressed a wish, more than once, that the otters might get the robber; but they never did: he would have given them some bother before they had him. Water-lilies do not grow here; the water is much too deep for them. The banks shelve down on either side, like those of a railway cutting; and no one bathes here, as the place 
has a bad reputation for everything except bream. A barrow-load might be caught at this point ; in fact, that quantity, or very nearly as much - for it was actually carried away in a barrow-did fall to the luck of one angler in the course of a single day's fishing. But this stretch of water has never had any fishing attractions for me; whenever I have visited the place, it has been for the sake of seeing other creatures. Now and then I have caught one of the bream, just to see what size they ran to. You fix on your plummet, down goes your line full twenty feet, then it rests on the bottom, and you have your depth. Bait with a nice lob, down it goes, and in about a minute you see your float run on the water and go under.

After a time you land a shiny bream of about the size of a pair of bellows; and then you wonder why you took the trouble to do it.

Scores of anglers to whom I have talked, especially those who have come from London, have told me that, although they have not caught one single fish, they have, as they expressed it, thoroughly enjoyed themselves in looking at things; and this, of course, is the 
secret of the pleasure of fishing-one is brought face to face with nature.

Of late years roach-fishing, or "roaching," as it is called, has become almost a fine art. Some, indeed, fish for nothing else. In old works on fish and fishing, the roach is called the "water sheep"; but all I can say about this matter is, that if the roach was ever of a simple nature, he must have succeeded very well in changing his character, and, if I might venture an opinion, I should suggest that the name of "water sheep" arose in the first place from the well-known gregarious habits of this handsome fish.

Old works on angling are like old herbals, full of fearful secrets. I have in my possession recipes of nostrums for catching fish, dating from the last part of the seventeenth century to the end of the eighteenth century, and also some belonging to the early part of the present one, which for nastiness might be safely ranked amongst the abominations of old Egypt.

Well-scoured gentles, prepared wasps, grubs from the comb, and simple white paste, made with very clean hands, are the best general baits. Sometimes good roach will play about 
pools where piles are driven in to protect the banks. They are sure to get round the piles if the weather is bright and warm, and then a blue-bottle fly on a small hook, with one shot above it, just sufficient to sink the fly beneath the water's surface, will do good work.

The finer your tackle is, the better will your sport be, always taking it for granted that you know the habits of the fish. River roach are very different as to their general habits, and even in some instances as to their outline, from those which are found in reservoirs and ponds; and of this fact all practical anglers are aware. One of the best fishermen of the present time, when he published his fine work on fishing, only gave a pen-and-ink sketch of the roach for general purposes, because the colour of this fish varies according to the waters or water from which it has come. The patience of a roacher might be proverbial; large fish bite so fine at times that the movement of the float is barely noticed. Yet the roacher is happy in finding himself in pleasant places, where cattle graze contentedly knee-deep in the herbage by the river, which is barred by locks, mile after mile. Or perhaps he will visit for a time 
some stretch of roaching waters where the only sounds to be heard are the splash-splash from the mill weir and the rush of water from the sluice-gates; there, under the alders and willows, he enjoys the peacefulness and the beauty of his surroundings to his heart's content, and he packs up his rod with reluctance when the time comes for him to leave it all. If the country is beautiful to those who are accustomed to it, being privileged to live their lives out there, what must it be to those who are only able to visit it at rare intervals! The craving to "get away from it all," as they describe their one day's holiday from London town, has become very general, and the honest rod and line fishers never do harm; at least I have never seen any done, and if they were not quiet folks they would not care to go "a-fishing " ; the matter speaks for itself.

The very look of some streams will be enough to stir your heart, even if you have never fished them. One such which I visit, not to fish, but merely to watch others doing so-as I am still a little bit critical regarding such matters-is all that an ideal roach stream ought to be. There stands the grey mill, with its eel-stage, alder-shadowed above, and the trees reflected 
in the pool below; the gate slams to after the cows which have come through it on their way from the meadows to be milked, but after that all is quiet. So still is it that you can distinctly hear the swish and flick of the dace rising and jumping at the flies on the shallow below the pool. For fifty yards below there are large stones and weeds; then comes a swim of from four to five feet deep between waving masses. of green weeds, and the swim has a gravelly bottom-nothing could be better. But even here there is a little something to keep things from being quite perfect, for below this fine swim is a staked pool with pike in it. Why they should slip up at times and upset the fishing is only known to themselves; but they do this, and will, it is to be feared, continue to do so, because it is their nature to.

It is tight-line fishing here. All goes remarkably well; four or five half-pounders are grassed, and so very contented is the roacher that one or two midge-bites have not been unduly noticed. Just as another good roach is coming up, something white shows for one moment, and the fine gut trace flies. up with a snick. That is a pike. "You will shift your tackle and try for him, won't 
you ?" I remark. "What!" . . . That was all he actually said, his feelings being too deep for words; but great meaning was conveyed in that single word 'What!'

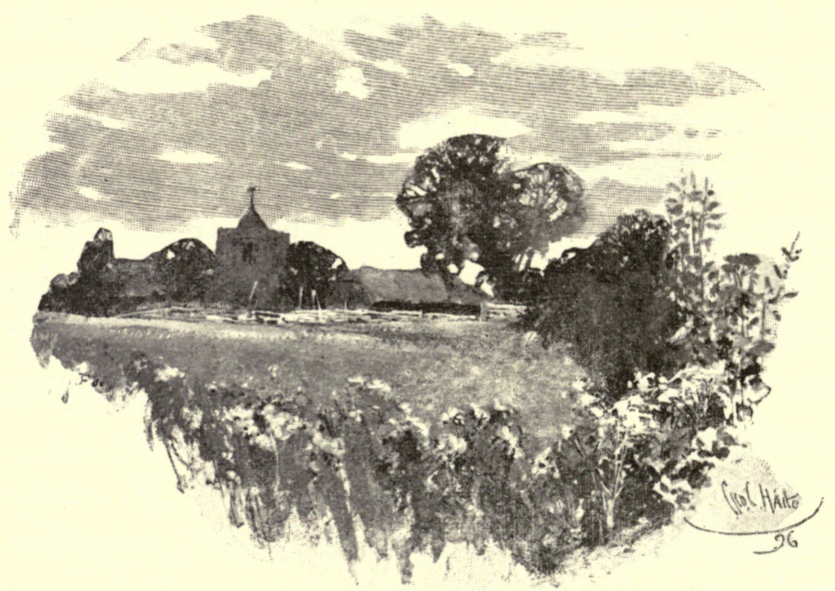


A U T U M N 



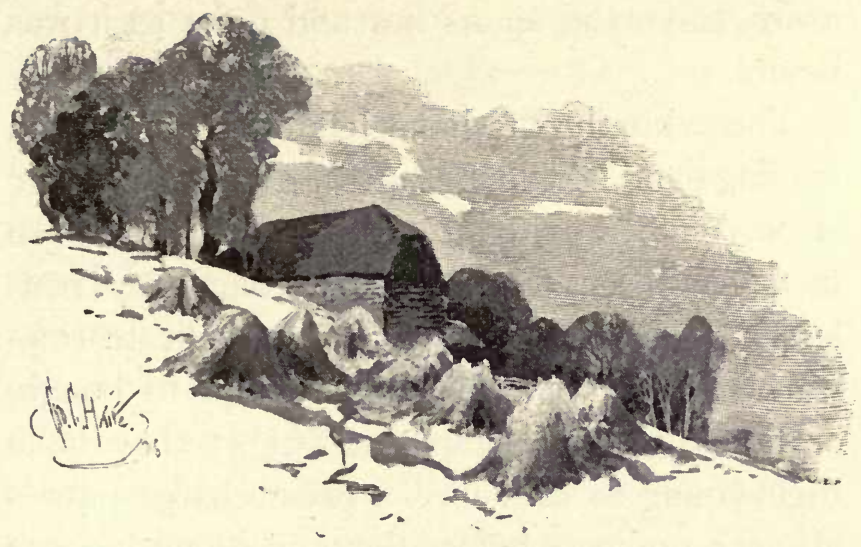

HARVEST AND GLEANING TIME

Scarlet poppies are blazing, blue cornflowers are making a brave show, round about the wheat-stems small, delicate-coloured creeping convolvuli run and twine in all directions, and the first rows of shock are seen in the fields. Reaping-time has come.

It is noon, and the atmosphere is hot and still; but presently there comes a faint sigh, followed by another-cool wafts of breeze, which are just strong enough to drift the plumes from the ripe thistle-heads, and, dying 
away, leave the air as hot and quiet as it was before.

The whitethroats have left off their hurried chidings and scolding chatter; their broods are strong on the wing, ready for departure. In fact, the insect-feeders are getting very restless. The willow wrens and the delicate treewarblers no longer flit from bough to bough, or hover over the topmost twigs; they have their young to care for-a great charge nowalso the prospect before them of a long journey to their winter home. Delicately formed creatures, they come and go, ruled by those wonderful laws of bird life that are only fully known to the birds that obey them. We who study them closely must, I am sure, honestly confess that a great deal has yet to be learnt about our small birds. For those puffs of cool air, which come and go so mysteriously, are to those fragile emigrants the first warning that they have not long to stay.

Very pleasant it is to roam by quiet hedgerows, and through cool, green meadows, just before the sun sinks down; and some very pretty bits of natural life can be seen by those who are contented with small pictures. Something stirs the hazel twigs. It is a 
"sleepmouse" (dormouse) prospecting industriously, but not for nuts, which he knows are not yet ready for him; he is on the hunt for some beetle, grub, or fly that will suit his fancy. Most creatures that fly and crawl in the daytime are now resting on the twigs or under the leaves. The dark-eyed, fawncoloured, bushy-tailed sleepmouse hunts for them, and when he has made a capture, holds them in his delicate forehands to eat. Seen thus he looks' a miniature marmozet. Quietly as you may have walked along, the blackbird has both heard and seen you, and now gives proof that, not without reason, has he been called the bellman of the woods. Loud and clear ring out his notes of alarm as he leaves the hedge and dashes away. From the cool, green after-growth of the meadows listening ears are cocked up, followed by heads. They belong to old and young rabbits out at feed. Finding that nothing comes after the bellman's riot to do them harm, the ears vanish. It is, however, very probable that one or two of those young, inexperienced drummers will not rest in their burrows to-night. A pair of brown owls are on the wing, and a nice little rabbit dotting here and scattering there is a tempta- 
tion too great to resist. How would it be possible for any owl with a keen appetite to distinguish rabbits from rats when just about the right size?

Over the trees, over the fields, now up, now down, dashing and wheeling and twisting, first on one side, then on the other, come a pair of heave-jars and their two young ones, whom they are teaching to get their own living.

The heave-jar, like the owl, is a gay-hearted bird, if he does sing at night. With the cares of a family on his wings, some of his light spirits leave him for a time, and just now his cry is only Cheer-er-cheer; then a full stop, as if he was considering over the matter. The full, rattling notes of Churr-ur-ur-ur-churr-urur-ur-churr-ur-ur, making the woodlands hum again, will be heard no more this season, for the birds will soon be gone.

Large-eyed, wide of gape, with an exquisitely mottled plumage, the fine night-swallow is one of the agriculturist's many benefactors; chaffers form the principal part of its food in their season.

The kestrel, or wind-fanner, is another most determined chaffer-catcher, and he is on the 
hunt till quite late. It is a very frequent sight to see heave-jars and a kestrel on the hunt for chaffers at the same time; but so very hawklike is the flight of the fern-owl, or, as it is more frequently called, the heave-jar, that both birds have been taken for one species. This is a very natural error; only those who have watched attentively the flight of hawks could tell the difference between them when on the hunt in the gloaming.

I have often listened in silence to strange tales, firmly believed in by my informants, about this bird; but to me the mottled and pencil-feathered bird was a fitting form to go dashing like a shadow over moonlit glades, and his droning song was just the sound to set you dreaming over the why and the wherefore of things in general, as you rested on the turf under the shadow of the pines, which murmur and whisper day and night, let the air be never so still. To my ear no sound is more pleasing, when the sun dips, than the hum of the pines and the Chur-ur-churr of the heave-jar.

Tick-tick - tick-tick-tick-tick-tick, then a pause, Tick-tick, rustle-rustle-tick-tick-tick; these sounds proceed from Oberon's fawn-coloured 
long-tailed cattle, the wood-mice. They are handsome little creatures, and quite harmless in their own domain, the fields and hedges, although when they get out of bounds, they work sad mischief. But as stoats, weasels, and owls look after them very closely, the mice are kept within due limits, if those self-appointed rural police are allowed to do their duty in their own fashion.

The yellow irises and the kingcups no longer light up the dark bush meadows; purple loosestrife and the cream-tinted meadow-sweet have taken their places, showing fine masses of contrasting colours. Moorhens, with their families - as many little ones as the otters and the pike have left to the parents-travel nimbly here and there, flirting up their tails and nodding their heads; or they swim in and out of the rush-clumps and through the water-lily leaves.

Near some high gravelly bank that slopes direct to the water you may, if you know where to look, see a family of kingfishers that have not yet parted company. It gives me pleasure to be able to state that I have not seen the wings, or head and wings, of this handsome bird on a lady's hat for a long time. When they were used for that purpose some brooks and 
streams could not boast of a single kingfisher.

The corncrake or landrail is thinking about making a shift ; for, now the meadows are close cropped and the corn is falling, the cover is not quite thick enough to suit him. He gets flushed too often, and as the bird is excellent eating, he is not only flushed but shot.

The Italians have a proverb that no fox is so cunning but that the furrier gets his skin at last. So it turns out with respect to the landrail, skulker and hideling though he be. Harvesttime does not suit him; indeed, when the corn is cut, bird-life is more or less on the move.

Pheasants, partridges, pigeons, rooks, starlings, finches, and sparrows are particularly busy, for they have a fair field to forage in. Mice, frogs, beetles, and other creeping and crawling creatures are there for them to feed on, let alone the scattered grains. Birds that are shot at this time, if their crops are opened, will be found to have less corn than other matters in them. Insect-feeders change their diet very frequently. When the currants are ripe, especially the finer kinds that are netted over to keep them for the table, harsh measures have to be used to protect the fruit; although the currant-bushes 
are protected. Small mice and frogs are luxuries to most of the larger birds, pigeons excepted, for these may be called vegetarians. You may see these in the fields when the corn has been carried. In regard to rooks, they are still credited by some with mischief. "Look at 'em; there they be, stockin' away; I reckins as I'll hev to run down an' holler 'em off agin ; they're up to summut."

This is what the young rook-scarer tells us. The black diggers are certainly up to something, for a lot of mice have their nests in the fields, and the rooks are making very minute observations of those dead leaves and withered grass structures. The frogs also come in for a share of their attentions.

I have watched rooks on the feed for years, at all times and in all weathers, and I know small deer are highly appreciated by them. Walk along any upland pasture path or track, and look down on the stubble fields below with your glasses, and you will see something. There they are, a great company of them, distributed over a couple of fields; all busy, all on the hunt, excepting the black watchers who are posted for the good of their community, perched on the tree-tops, or on the 


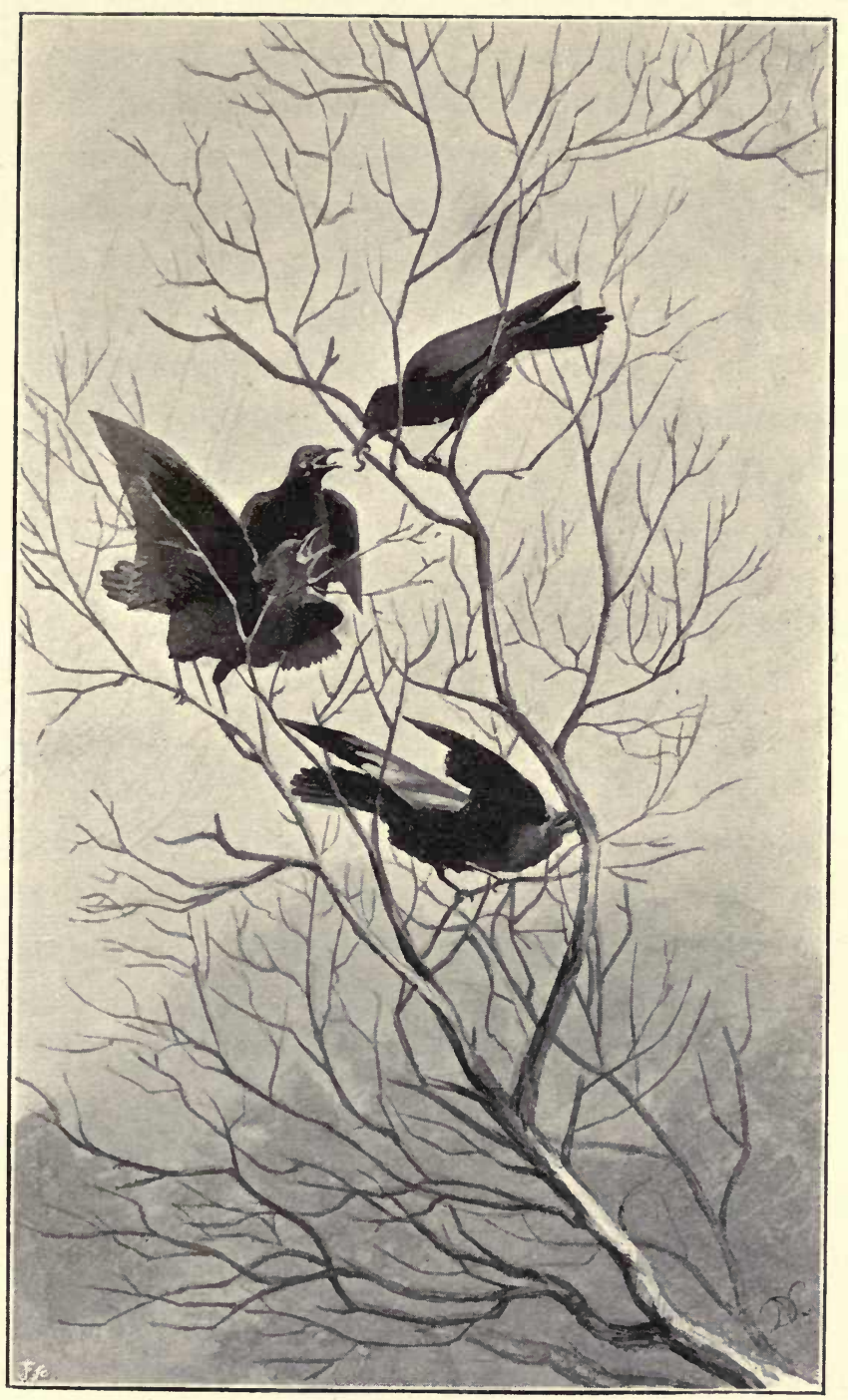

ROOKs. 

fence-rails. All at once you will hear excited croaks and caws from four or five of those that have been at their pickaxe work, pretty close together; and you will see them take long jumps, flap their wings, and give most vicious digs with their strong bills. The game is soon over, and each flies off with his capture to some place away from the others, where it is soon broken up and swallowed. When the mists hang over the water-meadows, ducks, coots, and moorhens will leave them to come into the fields for their share; if you stay there at night you will hear the cry of plovers and the whistle of the stone curlew proceed also from these searchers.

The few pairs of wheatears that still visit their old haunts, where at one time they could be found in numbers, flit and chat, as their broods get strong on the wing for passage; and a couple of shrikes, or, as they are called, butcher-birds-the only pair we have seen at this time-fly from bush to bush, perch for a few moments, cry Chack-chack-chack! and move on again. It is by these short jerky movements, day after day, that most of our small migrants, by easy stages, feeding as they go, at last reach the coast-line. 
Hedgerows, fruits, and berries are beginning to show some colour. As to the hazels, they are well bunched; the wild fruits are getting in order as future food-supplies for those birds that will come presently. The swallows are dashing all over the country. No matter where you may be, far out on the hills, or passing through the woods, if you look up, there you will see them, chasing their insect prey high overhead. They will be the last to leave us.

When reaping-or, as it is now called in southern counties, wheat-fagging-first begins, we generally have some perfect days. Those wanderers who make wild creatures their only study revel in these ; in fact, for the time, every living creature rejoices in its life. Even those that have had rubs in their contact with the outer world, with all its vexations, forget these for a time, and say it is good to live.

Red admirals and peacock butterflies flit before or around you; they are glorious creatures. If there is a bramble-bush near you, and the sun shines right on it, stand still and see them play, as they settle on the tinted leaves. Various causes make them, comparatively speaking, scarce at times. In some seasons, again, they are abundant. At this time, un- 
fortunately, the viper, no matter what his size, is really dangerous. Unless well acquainted with the whole family-as few are-you had best give the lot a wide berth, and just look round and about before you sit on a thymy bank or throw yourself on the heather.

Miles of heather of both shades of colouring, rose-pink and purple, lie all around us, showing in distinct patches on some parts; whilst the two species are about equally mingled on other portions of this glistening, sandy tract of country. Here are dwarf furze, green broom, and trailing brambles, with tufts of wire-like grass, where this can get enough soil to grow on ; the two latter will trip you up, if your foot should hang in them, and give you a nasty fall. Very few fir-trees show, and the few clumps that can be seen are ragged and broken by the fierce winds that rush over these open heaths; apparently they are fairly level, but deep hollows intersect them, where ferns and bush-growth flourish luxuriantly; also black alders, sallows, and dwarf-birch. It is easy to tell when you are nearing one of the heath-hollows, for the sand has soil mixed with it. The hollows are filled with soil-not very sweet, certainly; yet vegetation flourishes in the shape of low bushes and 
rushes. Knowing that the waters which I was bent on seeing lay in a western direction, I only examined some of the hollows that appeared to run in that direction; but they merely ended in a dead pond fringed round with sand. Not a tuft of rushes was there to break the bareness of it, nor yet a pipit to enliven it; so we are soon out of that hollow and on the heath again, to look around for bearings. Half-a-mile away a dark, winding streak shows below, which we at once make for-these are brook alders. If there is not water there now, it is moist along that winding hollow; so we decide to follow in the line of these, one of our rustic friends having told me that if I "could stick it"meaning that it involved a great amount of uncomfortable travelling-I "might in about a week, or it mought be a fortnit, see summat." Three times was that alder hollow broken by stout hedges that surrounded small farms, where there was soil that in the course of time had been broken up for cultivation. It is interesting to see the sudden changes from corn to fern brake, and from orchards laden with fruit to alder swamp, side by side. In past days all the ground that could be cultivated was dealt with; the rest remained as it is now. 
The scattered houses of one secluded hamlet -it was not large enough to call a village, even by courtesy-on which I dropped from some high woods above it, was built on the edge of what had once been a wet moss sprinkled with rush clumps. The main road ran on one side of it, four-armed sign-posts were numerous at the cross-roads, and at the end of the still moist waste was a fair-sized pond. Much has been written about the beauty and the extreme healthiness of the country, but a place may be very beautiful without being particularly healthy. One would not care to live near that waste, with the polluted stream running through it. But in this particular hamlet I wished to see the old church, because a man I met told me that there was a "werry old church stuck in a wood 't'other end o' the willage," if I was curious on "sich things"; and as I had had about enough for one day's tramping, I asked him the distance to " $t$ 'other end," as he termed it. "Oh, well, let's see. Well, 'tis within a short half-mile, I reckins."

It proved a very long mile; and when the place was reached, the entrance-gates, that led to the church through a path between trees, were locked. The church could not be seen, 
being in the wood, as the man said. Some one did come by at last, and on being asked if he knew where the person could be found who kept the keys of the gates and the church, he replied, “Well, I bain't werry sartin 'bout it, like; but if you goos back agin and meks inquirations in the willage, I dessay as you'll find 'em somewheer."

I thanked him, and passed on to the next little village, where the question, "Can you put me up for the night, and can you let me have something to eat and drink?" was answered much as follows: "Well, it ain't werry often as we is asked, fur, ye see, this is a bit out o' the track, like; but I'll ask the missus. What would ye like tu eat now?"

"Oh, cold meat, if you have it."

"Well, we ain't, for the butcher wunt call afore to-morrow-he on'y cums twice a week. Ah! here's the missus ; now we shall know."

Yes, we find we can sleep there; and for supper, or rather late tea, we can have newlaid eggs and bacon, and tea or coffee, unless we prefer ale or cider: we prefer tea. All is very clean and comfortable, but the same diet for every meal soon becomes monotonous.

When it got dusk I joined the limited com- 
pany that used the house. As our host was, like most of his class, a small farmer, the custom to the house alone not being sufficient for a living, the conversation of the company turned on crops, horses, dogs, and game ; whilst the general stock, such as cows, sheep, and poultry, filled up odd corners of the conversation whenever it flagged.

I ventured to ask if a celebrated pack of staghounds still hunted the district, and our host at once referred me to a grey-headed, wiry-looking man, that might have been, from the look of his dress, under-keeper, mole-catcher, or stablehelp; he had only left the kennels of a wellknown hunting establishment when the owner died, having been one of the kennel feeders. From him we had odd scraps of information. The dogs he tended were large hounds-bloodhounds, as they were always called by all the rustic population of the district. That they had been crossed with the bloodhound there was not the least doubt ; their jowls, ears, and build told that plainly; so did their voices. To look at, they were very large, heavy foxhounds, and they were named far and near by all that knew them as Lord - 's bloodhounds. That they were sharply looked after 
when out for exercise was a well-known fact, and it required no small amount of hard riding and thonging at times to keep them from doing mischief. One morning, when out on the main road, they caught sight of a sweep who had been down to the mansion to sweep the kitchen chimney. He was plodding along one of the field-paths well above the road. They sighted him, roared out their challenge, and were in full pursuit like a flash, followed by their attendants, just as hard as the horses could gallop. Old "Coomber" heard the hounds, and the shouts of those that were following them; but not before they had crashed through into the large field did he dream that they were after him. Fortunately for him, some trees were near; down went his sweeping kit, and Coomber was up one of these like a squirrel, with the hounds baying him at the foot of it.

Deer-parks and coverts for pheasants, to say nothing about the large fields with their partridge coveys, have a class of numerous admirers whom those who look after them would prefer not to see about. Desperate gangs have come from the borders of one county into another, got their booty, and cleared off again without being seen. Their 
plans are always laid long ahead. The way there, and the way back by a different route, is arranged away from all main roads.

One guardian of the coverts in this district had a pure white pheasant that roosted in a tree close to his house. White pheasants, or nearly such, are to be met with in most large coverts, but this particular bird had chosen the near neighbourhood of the keeper's house for resting at night.

After a visit from one of the gangs mentioned, this gamekeeper made the remark that no one would be able to get his white bird at night without his knowing it; in fact, he aired this bit of information considerably. In less than a week that pheasant was shot from its perch ; the keeper heard the shot, but never saw the man that fired it. The barefaced audacity of the act was the safeguard of the culprit.

Old cottages that have not been improved are to be seen as you pass along. Some of the houses that in past years, by the look of them, had been occupied by yeomen of a substantial class, are now tenanted by a very different class of people, who use them as summer residences. If they are four or five miles from a railway station they soon let. 
The interiors and exteriors remain as they were when the houses were built generations back, but the low ceilings and beams have been papered with the latest of paper decorations, the old diamond pattern lead-light windows have been taken out and replaced by fret lead-lights of mediæval pattern, and the furniture has been made to suit the age that the houses were built in-the heavy gables, quarterings, and massive old oak beams being painted a dark æsthetic green. What the exact name may be, we do not know, but in our young days this went by the name of "bottlegreen "- a compound it is of yellow ochre and lamp-black. To contrast with this sombre tone of colour, the rough-cast, in between the quarterings, had been coloured a delicate salmon-colour, which is now known, I believe, as cerise. All this is very idealistic in the bright summer-time, and history records some high-handed doings that were carried on in this vicinity, when princes and nobles hunted here with hawk and hound; but folks do not stay here in the winter, when the waters rush down from the hills and flood the roads, if they can help it. Before the leaves are quite off the trees, the owners of the cosily fur- 
nished and furbished-up old farm-houses leave them in charge of some one for the winter, and go back to town, to come again when the birds are singing.

Some moneyed folks carry their æsthetic fads with them out into the wilderness; but only a few, fortunately, as yet. On one corner of a wild heath, sheltered by a belt of high firs, I lately passed by a large house of many gables, the roofs being covered by tiles of a ferocious red. The gables, quarterings, and window-frames were painted peacock-green, the sashes pure white. All the outside doors were a faint rose-colour. About fifty yards away from it, on the other side of the newly made road, in its own garden patch, sheltered by birch-trees and sallows, stood one of the large old rambling cottages, grey and yellow tinted, covered with moss and lichens. This was in perfect keeping with all that surrounded it; the other was simply incongruous and out of place. One fine house stands in the centre of what only a few years ago was one of the most treacherous snipe-bogs in the whole district. It is very secluded now, for wet ground and alder thickets surround it; on one side only is it comparatively open, and that 
is where the woods slope down to the moor. Good roads have been made, that never have water lying on them, even in the wettest seasons. With the exception of the spot where the ground had been levelled for the house itself, the rest had been left in a state of nature; but plants and flowers from other lands had replaced those that once grew there. So cleverly has all this been done that it looks part and parcel of the district fenced in. The rill that once trickled through now forms a pond filled with white water-lilies; a rustic bridge of twisted and gnarled oak branches reaches from one bank to another over the pond; it is strong and solid, but the bridge looks as if a dozen axe-men had thrown it over in the course of a day. Fruit and vegetable gardens, forcing-houses, and pit-lights are all there in perfection and abundancea dwelling-place and a garden in what was once a reeking snipe-haunt.

So far as seclusion goes, it is as quiet and out-of-the-way as it ever has been. If we had not followed the road up, we should not have known such a beautiful place existed. It caused me to go a couple of miles out of my way, but I felt well repaid in seeing what 
could be made by judicious management and refined taste out of what was once a swamp that would not bear a man.

Next morning after breakfast we bade our host and hostess good morning, after being warned by him not to get off the hard track, in passing through a moss that was on our way, unless we travelled by the narrow up-anddown cross-country road.

I have seen mosses or moss-swamps before, but this could hardly be surpassed for wild beauty, although so far as size went it was only a long patch, whilst others run for miles. Still, before I got through it, it was more than enough for me. Young flappers were about, near the footway-too much wet does not suit even ducks-and snipe were near; and that was about all the life to be seen, with the exception of a rabbit or two. What there may have been concealed on or in those moss-bunches, ranging in size from a large circular table to a flower-pot, one could only guess. If one had placed one's foot on one of those gaily tinted masses of moss, one would have gone down through it and been smothered.

If to the natural beauties of such spots you 
have added, as we had, a heavy thunder-storm and a perfect deluge of rain, you are likely to remember it for some time. It is almost useless now going out in the wilds to look for wild creatures. Fires have so devastated whole tracts of country of late years, that all we are acquainted with in southern counties draw as near man and his dwellings as he will let them. So much has this been the case quite recently, that you may go for a distance of twenty miles now over the roughest ground, and not see a slow-worm, let alone anything more important. This is a matter that has been noticed by other field-naturalists with whom I have compared notes. Some creatures are now scarce where at one time they were a little too numerous. All birds have some traits about them that are impossible to understand. Just before that storm burst, a fine male cormorant in full plumage left a piece of water where he would have been in perfect safety, for no one would have seen him, to settle on the ridge of a house like a pigeon. We need not add that he had not been there a minute before he was shot, to be put in a fine glass case, well set up. The bird must have been carried out of its course at express speed. Immature birds I have known 
to visit certain lakes, ponds, and meres; but this, a full-plumaged adult, in August of 1894 , was, I think, an exceptional case so far inland, thirty and forty miles from the tide. That large stretches of fresh water, broken by heaths, woods, mosses, and alder swamps, all of them well stocked with fish, should at times attract the fowl at certain seasons, might be expected. The osprey or fish-hawk has not only been seen, but shot in the same line of country.

The fields are bare; only the stubble remains in those that will, for a time, be left fallow. Wild fruits and berries have ripened off on trees and bushes, the twigs only remaining on some of them, those that are most favoured by the birds. At this particular time of the year, the border-land so to speak between autumn and winter, all creatures are busy in and about the fields, the greater portion well on the feed while it lasts, and a few busy in storing up for the future.

"Samples of weather," as the country folks have it, come and go in fitful changes: for a day or two the sun shines out, brightening up the face of the country; then the wind shifts, and grey tones meet the eye far and neartones that vary in depth from warm purple- 
greys to the most light and pearly. This scale of colouring is etched up by bits of bright colour, formed by the patches of leaves that still hang here and there upon the twigs, combined with the brightly-tinted wild fruits and berries. Heavy fogs hang about, drenching the woodlands, and these end, if there is not air enough to lift them, in drizzling rain. Then suddenly there is a change: all is clear and bright once more, to finish with a sharp frost when the night falls. See what this has done in the fields. With the exception of the beeches, there is one continual fall of leaves ; in fact, they will be down in the course of the day. Although there is not a breath of air stirring, even the beech-trees are very nearly bare in places where the frost has nipped keenly.

The hedgehog, finding that the crimson clusters of the white-leaf berries-good to eat, sweet and mealy-are no longer to be found, travel and root as he may, has decided to curl up for the season; but even in his own domain the little hedge-pig is not quite secure. $\mathrm{He}$ has his own four-footed enemies.

Humming, whistling, and cracking through the woods and over the fields comes the keen north wind, clearing off all mists, and drying 
everything above and below, rattling the crabs off; and the beautiful red and yellow fruit lies at the foot of the trees, not in gallons, but in bushels, where the trees are numerous, and in out-of-the-way spots that I know, to be covered ultimately by drifting leaves, and finally ripened. This is a matter of time. We have found crab-apples sound and in first-class condition months after they had fallen from the trees: so had some other creatures, for the leaves had been moved about in all directions to find the fruit. The hedge-bullaces are not speckled over with brown yet; and the black-jacks, as the wild plums are called, do not yield to the gentle nip of finger and thumb; but they will soon be fit, and when that time does come, other creatures will have their share of them as well as yourself. In that matter the advantage is certainly on their side: you may have seven, or it may be ten, miles to go-that is really about the distance at the present time-before you can get where they grow; whereas, birds, for the time, live and roost there.

The leaves are whirled in cart-loads all over the place; this dries them completely, and the creatures that line their winter homes with them are not slow to take advantage of it. 
For hours we have watched squirrels making up their bundles to line their winter nests with. Even here, with Master Scug's care, matters do not go right at times; cleverly as his forehands have made the bundle up, I have seen it slip. Then the little fellow would show temper in utter amazement that such a mishap could take place; up went his ear-tufts and his tail, but only for a few moments; with stamps and scolding chatter he dashed here and there, collecting his scattered treasure, and finally carrying his bundle off into safety.

The dormouse, although it does haunt and hunt the nut-trees and bushes-for there is a very wide difference between the two-will not as a rule confine itself to them when the winter nest is made. For if sloe-bushes or pickets are in the hedgerow or on the copse banks, you may look about the centre of them for it. If, as is usually the case, the bushes are well laced round with brambles of the most robust and thorny nature, the chances of a capture will be slight; he may be drowsy, but he is not asleep yet-far from it.

With the greatest care you find that your hands are scratched severely, and that matters are not quite pleasant about your legs, but 
still you persevere. At last your hands are near the grass ball; very gingerly your fingers touch the sides, so as to close round it. Is he at home? you think, after all this trouble.

$\mathrm{He}$ is, for he slips through, not out of, his grass house, glides over the twigs, sits up for a moment to look at you with his full dark eyes, as much as to say, "Serve you right for meddling!" and then he springs down into the thick tangle at the bottom.

I have made captures at times when I kept pets, but my misses have been far in excess of my captures. Torn hands, torn clothes, and a general all-over feeling of being outwitted by a mouse, are slightly humiliating. Sleepmouse he may be called, and rightly so, for the dormouse does sleep both soundly and long; but in his time-that is, his appointed seasonsa brighter or more wide-awake creature than the little dormouse it would be hard to find.

A southerly wind and rain with it, sheets of rain that turn when the wind lulls into a steady downpour. The brooks are bank-high and the rivers in flood; as to the fields, the furrows are edge-high with water that is not able to get away. A dreary outlook this, and far more dreary to be out in, as I am, not from choice, 
but necessity; some matters must be attended to, let the weather be what it may. Weather not fit for a dog to be out in it is, I am told as I start on my journey, eleven miles. I must go through it all. Not a rook out, and it takes something to keep these birds at home; not a sound is to be heard but the splash and drip of the rain; for the time the land is drowned and silent.

The rain ceases, the waters lower, and the furrows in the fields are dry, but the fields are no longer tenantless. Where have the birds come from all at once? Flocks of small birds there are, and in the centre of the stubbles are hosts of wood-pigeons. As to the rooks, they have been in the grazing meadows, and they rest for a time in the trees, too full of drowned-out worms to care to fly.

Acorns will come in presently, for the pigeons and for the rooks also; but all the time that scattered grains of oats, barley, and wheat can be got at, after rain, nicely moistened to a sprouting point, the pigeons will hunt for them. Field and hedge gleaners leave little behind them when they have done. Wild creatures are not the only ones that 
glean when the crops are off. Sheep find sweet feed in between the rows of stubblea bite here and a bit there, as they move along; and the peewits follow the sheep. All through the year, the land, no matter whether it be in cultivation or not, provides something for the various creatures on or about it. One lot of gleaners we have missed of late years - the women and children that at one time one used to see coming home at night from the fields with their bundles of wheat on their heads. There may not be any necessity for this now, for bread at least is cheap, which is certainly a matter to rejoice over. And customs, no doubt, have changed with the times, for old time-honoured customs have of late not been considered to constitute prescriptive rights. The custom of gleaning may be carried out now in some places remote from great labour centres, but in our own immediate neighbourhood it has died out.

It is the same with hedge gleaners; they are no longer to be seen with their bundles of dead wood going home along the roads. Not that their wreckage was taken from the hedge ; it was picked up between the copse and the wood near to it. If you walk along country 
roads or lanes now, when the people are coming home from work, not one in twenty will you see with a faggot of either lop, top, or rough wood. They will tell you that they have now to buy all that they require, which at any rate puts them on a more independent footing; and as ordinary grates have in most out-of-the-way places taken the place of brandirons and fires on the hearths, large wood could not be burnt there.

Just at present there appears to be a slight hitch in the movement for the general welfare, aided as it is by all the modern improvements, ready to hand, for working it along. Time will prove all things; if the changes had been gradual they would not have been noticed so much, but they have been extremely rapid, and the rustic mind is slow in accepting them. 


\section{VII}

LEAFLESS WOODS AND GREY MOORLANDS

As is frequently the case after rain and rough gales, there is now not a breath of wind; one or two leaves that have not yet been blown off, are motionless ; there is not even a quiver about them. Leaf-sweepers they call these November winds; the fierce gusts catch the leaves up and carry them in one direction, to drop them again in sheltered hollows in cartloads, where they are gathered without the trouble of raking up; fine leaf-mould for the forcing houses and frames.

The birds will certainly benefit by the blasts, for they have laid bare a vast supply of acorns and beech nuts. So much bird provender has not been seen for years; the fall season has been a bounteous one.

As we pass along we do not hear the rustle and scrape of leaves, caused by the pheasants scratching amongst them, or by the breast 587 
ploughing and wing flicking of the woodpigeons. What these must ordinarily do to get at their food, has been done for them by the winds now at rest. Heavy rains and gales of wind do good; "the rain washes the air clean," our folks say in their homely fashion; and certainly the wind carries the ill vapours well away.

Just as we are going down a path, we meet two youngsters who have come up it with a large "trug" (basket), full of crimson and gold fruit crab-apples, our own old, wild English fruit, beautiful to look at, and eatable now, after their thorough ripening off under the leaves. The youngsters said they should have "let 'em lay there a bit longer, but they knowed the wind had unhapped 'em, an' they reckined as they'd better get 'em afore they fell down." They had got "mother" more than a bushel for "varjuice"; and these were going to be put by for Christmas and the New Year.

Some of our readers may not be familiar enough with woodland specifics to understand that crab vinegar is called "varjuice"; it is the cleanest, sharpest, and most aromatic woodland produce that I am acquainted with. 
Nearly all cottages own a small press, for their fruit crops are large in the outlying districts; so the crabs are simply ground up, pressed, and the juice pure and simple is put in stone bottles and kept ready for use. If it is a case of sore throat, this is a gargle that will cut its way through anything, as they say, cleansing as it goes. Then if any part is inflamed, a linen bandage lightly placed on, saturated with "varjuice," will cure it, as I know from experience.

On the moors one day I met with a very serious accident. When faggot wood is cut, and young firs are thinned, a sloping knifelike edge is left close to the ground; and as the wood is only about as thick as a man's wrist, one blow of the axe cuts clean through. Hard wood scrub gets cut as well, such as oak, holly, and blackthorn; these snags are really dangerous to step on, concealed as they are by the cover that springs up like magic all around the stems. Many a valuable hunter has been lamed for life when the fox has crossed a stubbed moor, through bringing one of his feet down on a "stam"; as the hard wood-stems dry, some of them split up, and there they are, out of sight, but sticking up 
like nails. In one of my rambles I had the bad luck to jump on one of these split-up stems; one of the snags cut through the side of my stout boot, and pierced the side of my foot. The result of this apparently slight accident was to me serious, and for some days I chafed under forced inactivity. Then, as I was away from home, a stout, motherly old dame took me in hand. She brought over some "cooling-stuff" for me to drink, and a quart of varjuice for wet cloth bandages-to be used at once. That night I slept like a top, and in the course of a week was about again, without so much as a limp.

Recently, right out in wild lands, I passed some crab trees that had been loaded with fruit, but had been gathered for varjuice.

Some cottagers even now distil their own garden herbs; plots are set apart for growing them. As to the wines they make, they are not only wholesome, but medicinal. Those who have had a bottle of real dandelion wine given them, when it was needed, are not likely to forget the benefit derived from it; nor yet the virtue in cowslip wine, amber-coloured and beaded, a glassful of it scenting a room with meadow odours. Pickets, and the large, dark, 
wild plums, the size of marbles, are gathered and put down in spirits, their valuable astringent properties being fully understood by the woodlanders. Then there is that time-honoured Christmas drink, elderberry wine, the country folks' nightcap, as it is called; this is the real recipe for it; the so-called elder wine they would not look at :-

A bushel of elderberries, the same of blackberries, the same of sloes, or pickets, with loafsugar-not coarse moist-according to taste. This when properly made, and taken hot or cold-I prefer it cold-is, as they say, not to be sneezed at. Taken at night hot, with a slip or two of bread in it, when the weather is bitter cold, it is really, as they say, quite as good as extra blankets.

Then the "cider beyond compare," as they term it, made from the choicest fruit, and the effervescent gooseberry wine that requires so much careful looking after, so that the bottle shall not burst. No modern thermometers are to be seen in these large cottages, yet very rarely do things go wrong: for a bottle to burst is a rare occurrence. The sale of their surplus fruit enables them to buy loaf-sugar to make their wines with. The presses and tubs, also the 
very large stone bottles, are heirlooms. You will hear them say, "My mother left me these; I was eldest darter like, an' her mother left 'em to her."- Yes, and other things they make; good, honest common-sense teaching them to use that which is close to them, and to be content with it, because it is both handy and good.

There is always something to be seen in the woods. You may go there a thousand times, and yet not learn one half that they can teach you. There, before your eyes, if you will but see it, are exemplified the two problems-that of life, and what we call death. From under the dead leaves new life is already springing up; and although the leaves are off the trees, you can see that when the time comes they will burst out again. Bud formation, the new growth, is already indicated faintly. If you walk through the fir woods and inhale their life-giving and soothing fragrance, you scent the very life of the firs.

At their roots you will see that evil, but beautiful fungus, the scarlet abomination of the woodlands. Never a one have I passed yet, leaving it behind me. They are most lovely as vegetable productions, but they can be used 
for a terrible purpose; they have worked evil, though at the present time they are not used to the extent they have been. Yet even now the baleful preparation of that fungus is known to a few, but they dare not practise with it, thanks to the efficient police supervision in certain places.

Birds that belong to the woodpecker tribe, or family, are generally supposed to spend their lives shinning round and up trees for a living. In the latter part of the autumn season the birds of this family spend a considerable amount of their time on the ground; even the little tree-creeper is to be found there also, although never far from the bole or roots.

As to the nuthatch - that agile little fellow who can go up or down a tree, round it, or progress in the most expeditious manner under a bough, back downwards-he has a decided preference for the ground in the autumn season. If a bit of short turf is near his haunts, he will get on it, and he can travel swiftly. It is most amusing to see the grey-backed, rich buff, or orange-breasted bird shoot himself over the turf with long hops, or rather leaps, giving out his liquid notes as he goes along. Now he stops, stocks away with his strong bill, eats what he has dug up, and goes on as before. If 
you stand quietly by any hazel hedge, you may hear this active bird hunting for the last nuts that have fallen and got covered with leaves.

Old gates are numerous in pasture fields that are bounded by the hazel hedges, and the gate posts are of oak. Now, all old oak posts have weather cracks on the top of them, of various widths and depths. The nuthatch looks out for one that will suit his purpose, and carries his nuts there. He is never deceived by a bad kernel; he fits his nuts in the crack as though in a vicethere is not the least fear of its falling out-plants himself firmly in front of it, and digs away in the most determined manner. The shell is soon broken up, and the bird has his well-earned food. Sometimes the nuthatch works away at his nut, cracking until the "dims" come on.

At the foot of the post, if you look, you may see a small handful of broken nut shells, when the post has been used for any time. The woodpeckers, the pied and the green, frequent the ground more or less as the season comes round.

Many forms of insect life, mature or immature, are in the ground; and the woodpecker family, with their pick-axe bills, are the very birds to dig that insect life out of it, and 
in the most adroit manner. They were not doomed to constantly tap-tap-tap at the treetrunks; in the fall the greater portion of their food is on the ground, and they naturally seek for it there.

If you follow the downward paths through the woods, when you get clear of these, you will surely come to water, either in the form of brook or pond. As some of the ponds have long since been abandoned, being no longer used for the purpose for which they were originally intended, they are now very much overgrown with aquatic tangle-reeds, sedges, iris, meadow-sweet, and so forth. Still the main channel runs through unchoked, and that is deep and still. When the pond gets too full, the water simply flows over the rotting old sluice gates, that are never drawn up now ; in fact, I very much question if they could be without pulling them all to pieces.

When the growth I have mentioned dips down, year after year, it forms ultimately a thick floating platform that you can stand on with perfect safety, if you do not jump about. Outside this, very fair pike are to be found; not large, only from four to five pounds in weight, but nice, handsome fish. 
Just in front of us, as we take the last turn in our path, we see a figure leaning on a gate, the road from which leads direct to one of the ponds mentioned. The man has a stick in his hand, about six feet in length, held country fashion, by the middle. When we get to him, the recognition is mutual, and he grins all over his face. Then he turns his stick up, and we see it has a good fork at the end.

"Ah, well! you have been fishing, or you are going to, which is it?"

"I'm a-goin' now."

"Have you got baits?"

"Yes, in the hedge." Will produces a large, wide-mouthed pickle bottle, with three nice bright gudgeons in it, remarking that there was quite as many as he'd want, perhaps more. "Coming down?" he asks. I nod silently. Down through the alder copse, over the sedge hummocks, into the dead uncut reeds - I make my way carefully through these-to the deep water channel, carrying the pickle bottle; thereby aiding and abetting Willum in his fishing. From his pocket he brought out a fine water-cord line, with a large perch hook, whipped on to about four feet of fine gimp. The line was wound on 
a brewer's bung cork, with deep notches cut to receive it ; a capital contrivance it is.

"Hold the stick," he whispered.

Then he got a gudgeon out, hooked him just below the back fin, not in his back, placed the line over the fork, and coiled the rest of the line round his hand. No float, for, as he whispered, the less the bait had to hamper it, the more natural it looked. Then he gently dropped it about four or five feet out in deep water, just off the reeds' edge, and paid out line; or rather unwound it from his hand, as the gudgeon swam about.

In less than three minutes the line was going over that fork rapidly; then it stopped. Giving me the stick to hold, he gathered up the slack line, hand over hand, until he felt a strain, then he jerked a little. There was not any need of this, for when a pike gorges, he naturally hooks himself. No play did the pike get, for the tackle was strong; we kept the line clear from fouling, and Will pulled it up on the dead sedges. One cut across that fish's vertebræ, and he was perfectly quiet.

"Try for another, Will," I whispered; "they generally go in couples;" and in less than ten minutes number two shared the same 
fate. At a rough guess, the handsome pair weighed ten pounds.

As I did not care for any myself, the pike were nicely arranged in the shooting pockets of Will's coat. They were not conspicuous, for shooting pockets run all round the bottom of a coat. We then left the place as we entered it, leaving the forged stick and the pickle bottle in the alder copse.

This was not contraband fishing; but game being in the surrounding covers, Will, as he lived in one of the cottages with his mother, did not want to be suspected of game searching. $\mathrm{He}$ or I had as much right there as other people. Before leaving him, I asked who had taught him that trick of pike catching.

"Larnt me? why, yerself," he replied, "last time you bided about here." I had forgotten all about it.

The moors look bare and dreary, great expanses of grey green. I fear this is only the preliminary step towards building. One forester observed to me that the moors seemed to get less and less. Some birds are not to be found at the present time where they once were in numbers in their proper seasons. Where we used to see ring-ouzels, we now see 
partridges, a sure sign of reclaimed land; for the partridge, like the sparrow, follows closely on cultivation. I have seen a covey of partridges on the new-made lawn of a new mansion, and I have known them nest in the first cultivated flower-beds that were ever seen there. If you spring a black-grouse or ring-ouzel, or if you hear the green-sandpiper, rest assured that matters are in a fairly primitive state.

The last-named bird dashes down in the most unexpected places, but it is only for a moment; he finds a house and men about where they were never seen by him before, so he just whistles, and flights it. Moorhens are now seen where wild ducks used to be met with; another sign of cultivation. They come on the lawns from the moor ponds and streams; and just to show their perfect appreciation, peck the hearts out of the young green stuff, for which they get horse-hair collars, noosed (and quite right too), for thieving.

The moorhen in his own place is all right, but not when he develops a taste for garden produce. If you wish to see or shoot hawfinches, too, go somewhere where peas are grown in considerable quantities for the table. They don't give the field peas a turn; they 
will have the best produce, if they die for it ; and this they certainly do, three or four at a time.

"How is this, then?" I ask a man that I met on a wide moor, driving a donkey before him, on the border lands of Sussex and Surrey. "Why, the place is bare!"

"Ah, I reckins 'tis jest that; you've hit the mark there; the firs is cut, and the heth (heath), an' the fuzzes (furze), an' the rest hev bin burnt. Look at it, I be 'bliged to shift my old moke about from place to place, an' peg him down where a bit o' feed is left. You don't see no hosses, nor yit cows nor sheep; you wunt no more, I reckins; fur this 'ere common moor is sold, an' they be goin' to build houses. All this 'ere cover an' feed hev bin ruinated, fur 'em to see where the best places wuld be fur 'em to stick 'em up. They hev started this 'ere job afore my reckonin'."

The houses are not for the working classes, any of them ; probably the lords of the manors have let on the ninety-nine years' lease system ; some of the structures that have been put up will last about that time, if they are well looked over at intervals.

How it will all end, time will show. People 


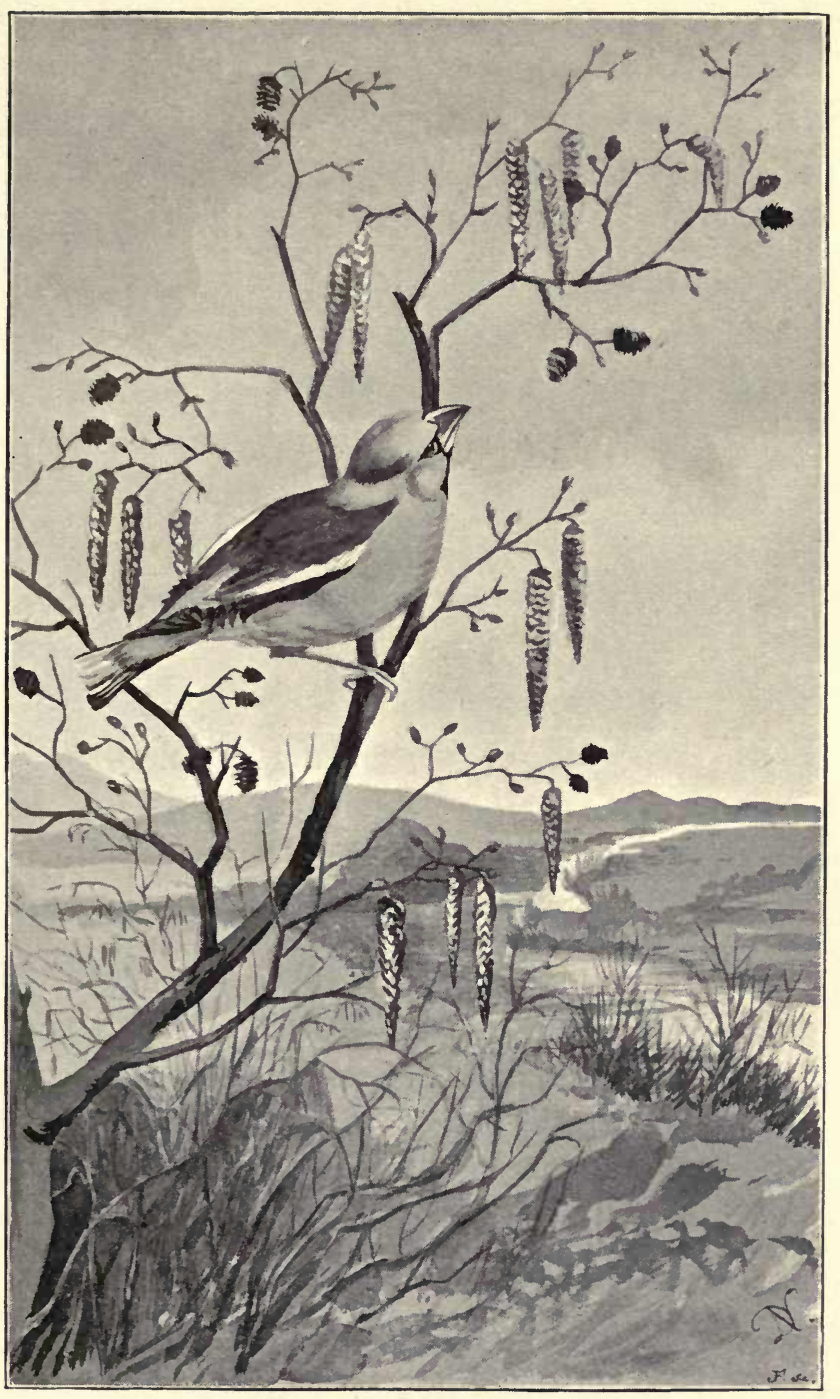

HAWFINCH. 

may come to a place to suit their own interests, and bring a large amount of money with them, but others can please themselves as to their receiving them or not. The natives of the soil often do please themselves, to such purpose that some of the new comers have apparently found the air too enervating, have sold their new houses, and gone where things in general suited them better. If Æsop's good old fables were read and studied now, as simple folks used to study, and profit by them, how many heart-burnings some folks would be spared.

If you wish to think matters over a bit, walk through two or three miles of fir-woods ; "lootering" along, not caring what time you get through them. It is quiet there, and matters clear up a little before you leave them ; a feeling of perfect rest after a time steals over you.

There will be breaks and gaps here before long, and bare hill-sides, for in some spots the trees have been felled at the base of the hills. When we inquired as to the reason of it, I received the usual answer, "They're goin' to build."

I have been told a great deal lately by old 
people, men and women, about what they had been accustomed to do when they were young. The rights of common lands of which they talk must have existed, otherwise the old owners would not have allowed the cottagers to do what they did without questionings. In the old days folks may have been tolerant in some matters, but they were to a man tenacious about all that concerned their rights; either way, their own or their tenants, from the highest to the humblest. One old squire, I remember, was appealed to by a new vicar, to use his influence in stopping the villagers from playing cricket on the common on a Sunday afternoon; the living belonged to the gentleman in question.

"Eh, bless me! what is that? play cricket on a Sunday afternoon? I never knew they did. It's a capital thing. Damn 'em, let 'em all play; it will keep some of them out of my coverts." I give this just as it was spoken ; the good old squire did at times use very homely speech, and he chatted to all he met, man, woman, or child. I can see him now, as I write this, coming along with his walkingstick weeding-spud; his pottering old pointer at his heels, and his old Skye terrier in front of him. 
As is usual in real old country places, the church was close on the green. Just opposite the old lych-gate were the stocks, fronting the church porch; about forty yards away was the comfortable-looking public-house; and somehow the reverend gentleman took offence at the stocks. He suggested that they should be removed, as relics of a barbarous past.

"Eh, what?" said the squire; "I'm glad that you've reminded me of them. I'll have a covering put up over 'em like that of the lych-gate, to preserve 'em. And when the rascals come out of church, it will remind 'em of what they deserve, but don't get."

After hearing a better sermon than usual, it was the habit of that congregation to go direct to the public-house, in order to talk it over. I have made one of that party at times, so I know all about it. And better still, the landlord of that pub. being a churchwarden, if he knew that one of his favourite anthems was going to be sung, he always invited the mixed choir into his house, "Just to wet up a bit fust," as he said.

The parson objected to this discussion as to the merits of his sermons over hot brandy and water, and on a Sunday. Spiritual and 
secular matters were not to be mixed up in that fashion, he said. So one day, meeting the squire, spud in hand, and logs at heel, he asked the latter to compel the landlord to keep his public-house closed on the Sabbath day.

Looking the reverend gentleman straight in the eyes, the squire replied, "Have I not presented you with a very decent living?"

"Certainly you have, sir ; but_— "

"Then be satisfied; the churchwarden has his living to provide, so do not refer to this matter again."

I confess freely that I have learned more in talking to many of those old gaffers that were wont to gather about the settle of a roadside pub., than in many places which are supposed to be far above their level. A pint, or for the matter of that a couple of pints of ale, and a few pipes of tobacco are cheap luxuries, and they are often well deserved. My knowledge of the people has, as I have often before observed, been gained in their midst. I belong to themselves, being myself but a plain workman. 


\section{VIII}

MOONLIGHT AND DAYBREAK

"Hoo-hoo-hoo-hoo-hoo-e-hoo-hoo-hoo-hoo," shouts out our old friend, the brown owl, from the top of one of the great trees that surround us, for this is his own special domain. Moonlight is beautiful at all times and seasons; but when a large wood, free from stunted undergrowth, is lit up by the soft light of a full moon, a network of light and shade is seen above and below that could not be seen elsewhere, for the light creeps along the interlaced branches, looking like silver and ebony. Before you have fully made out the fitness of this comparison to your satisfaction, some of the huge silver beeches come in the range of light. The shadows from the limbs and branches above chequer the boles, creep down them, and over the carpet of fallen leaves ; shadows softly moving; at one time broken up, then for a short space they are massed, 
to break again, and scatter themselves in all directions. Where some of the trees have fallen, leaving gaps and open spaces below, bright blue-green patches show, about which dark grey dots are astir. These are rabbits feeding on the short tender grass ; for nothing is left bare long; directly through some natural accident a larger growth ceases to exist, a smaller one of a very different nature is ready to take the place of it.

Old woods, when leafless, if the moon is high up and bright over all, provide a series of everchanging pictures. Nothing, you fancy, could surpass that effect of light and shade; but the light shifts on, and, if possible, another picture is presented more beautiful than the one that has gone. That owl's hooting is about all you are likely to hear, and he will not shout to the moon for any length of time, for his mate will join him on a hunting expedition, far away from his sleeping quarters. And now the hooter has flighted, and not even a woodmouse rustles the dry crisp leaves which are so thickly gathered under the trees. From a distant farm the shrill crow of a rooster is heard with startling clearness. If Reynard is about and is sharp set for his late dinner, 
probably he will canter off towards the spot whence the crowing proceeds, whilst at the same time his sensitive nose and fine ears will inform him if any creature is handy for him to interview as he travels along. Predaceous creatures have to work hard at times for their food ; for, if they are gifted with organs of destruction, those that they prey on are equally gifted with the organs of self-preservation.

The soft light fades slowly, lights and shadows mingle for a brief space, and then the woods are one great mass of shadow, and we pass, as quietly as it is possible for us to do, up the main ride that runs through them. This is one of the most stringent rules to be observed, if you wish to be at peace with yourself and other people-move as quietly as you can when studying nature at night. Avoid all farms and lonely houses as you would the plague, for large dogs of a courageous breed are the guardians of the night there, and they are loose. Quite apart from this, a footstep on any road at night will cause dogs to challenge, and thus disturb their masters. It is far more satisfactory to go out in the wilds at night, where you will not have any company but your own. 
It is moonlight on the waters, a summer sea as they call it, just enough to send the craft along in a smooth fashion towards port, for the small fleet of boats is homeward bound from open water. Not even the curlew's whistle is to be heard, for these birds have not left their moorland haunts yet to visit the tide. There is no sound but the lip and lap of the waters round the piles at the base of the long seawall, that winds and twists like some monstrous form, and vanishes in the distance. The marshlands that the wall protects show as one vast flat of silver-grey, obscured in places by floating fogs from stagnant lagoons.

But seawards all is bright and fair; small patches of light show about the size of a tablecover, and the water where those patches show is one long line of molten silver. The fleet is making the mouth of the harbour creek. To one not acquainted with the locality of this network of waterways, as dangerous now as it was in the past, it all looks like open water; but there are sudden bends where great arms of the sea rush up, miles inland, to the safe harbours of fishing towns.

It is remarkable how far you can hear sounds on the water, or borne on it at night. As we 
have made for the mouth of the harbour creek, the boats will pass in comparatively near to us. Here they come, six of them, one after the other, their usual style of entering the creek, for obvious reasons. A voice on board the leading boat, one that I know well, strikes up in a "shanty catch," one that is too old for us to get at the date of:

"Oh, the herring loves the bright moonlight, And the mackerel loves the wind; But the oyster loves the dredger's song,

For he comes of a gentle kind."

The song proceeds from old Craft's son; he is giving vent to his feelings on making port on the harbour tide.

The boat passes on, the others follow silently ; five have gone round the bend, the sixth has not reached the creek.

Some one on board of her is singing, or rather, wailing out like a sprat loon, "The Banks of Allan Water." It is old Piper Owlet, crooning to himself in the joy of his heart over the moonlight and the ripple of the tide. This and "The Isle of St. Helena" were Piper's favourite songs; in fact, the only songs he knew. "St. Helena" was looked upon by all of us as a special treat; as he was wont to 
observe, it consarned the nation. He could not often be coaxed to sing it. When the old boy did consent to give it, you could have heard a pin drop. As to his face-well, it was grave beyond conception; and the best of the song was, a good sound moral, as Piper said, was tacked on to the end on it. In his best days he no doubt owned a good tenor voice, but this had got out of gear a bit, and Piper now wailed rather than sang. For all that, none were listened to with more attention or more respect than he; there was something pathetic about both the song and the singer.

As old songs are passing away, I will give my readers the first and last verse of "St. Helena," as Piper rendered them :

"Now Napoleon's away from all wars and all fighting, He's gone to a place that he ne'er can delight in ; He may sigh to the winds that sweep the wild billows, As he looks out o'er the seas that surround St. Helena."

The last verse contained the moral :-

"Now all you of high estate cast aside all ambition, Or by some decree of fate it may change your condition; Be steadfast in time, for what's to come you know not, Or your fate may be like his on the Isle of St. Helena."

A faulty composition, yet to my mind well suited to the wailing voice of the singer, and it 
always pleased those who listened to him so intently. Time and place have much to do with the fitness of things. The wild scream of the curlew would be sadly out of place in the woodlands; but on the beach, with the lap of the tide for accompaniment, it is in thorough harmony.

Sometimes when shadows pass, in ever-varying fashion, in the moonlight, we think of those who have passed away from us like shadows, and it seems almost yesterday that we hailed each other on the foreshore and by the tide.

The moon is shining bright and clear; dark masses of cloud roll up from the west, but they have not yet got high enough to pass in front of her. What a glorious sight old Holmbury is by moonlight, with vast portions of the weald below in deep shadow! Who could do full justice to its beauties, the fir woods, and the tracts of heather? Glade after glade shows, as you wander along over the soft green turf, lit up by the light of the moon. There is colour here, even by moonlight; subdued in tone, but still colour. The fir woods are deep purplegrey. As to the heather, it looks like a vast series of carpets spread out in all directionsthe deepest madder-brown heightened by the 
turquoise green of the grass rides, where the light falls direct on them, and the glistening of the stone heaps and sandy paths.

To the left of us the hill of Leith, looming out high from the vale below; on the right, Ewhurst and the extensive range beyond, running down towards the west. It is a vast picture in monochrome, lit up by silvery lights ; not a fern owl churrs, not a beetle goes droning by, for the clouds are getting higher, and they are heavily charged with rain. But with the exception of a slight shower, just enough to bead the cover, and cause the bramble leaves to glitter, the clouds pass over, and the moon is, as the children sing, as bright as day. Let us stand quite still to let the scent of the cool earth reach us, and the odour from the firs, heather, grass, and ferns, with much more that is hidden from sight. Life is in the air by night as well as by day, the life of the hills and the woods, the life of a summer's night that has no real darkness, showing some of Nature's workings so plainly, that those "who run may read."

Moonlight on the sands, and floating mists that wander about high up, veiling the moon's brightness for a time, as if huge curtains of 
gauze had been drawn in front of her. A capful of wind up aloft drives the mist clouds away. Then the sands and the water show out as one vast white plain. Very beautiful it looks ; but it is a treacherous beauty, for the greater part of these are quicksands, that boil and bubble at every tide. That dark streak lit up by a flash is a cut in the sands, where the water has already forced itself. If you could stand there and look at it, you would see the water rushing down that cut like a mill-race. Live sands are there. Marks exist on all these live sands, showing where you can travel in comparative safety; but you must know them well, or woe betide you!

Getting on the wrong side of a thin line of stakes, driven deep down in the solid part of the sands, simply means being washed up dead by-and-by. It is not on the surface that the sands boil and bubble, but below, and before you are aware of it you are ankle-deep. On either side all pools show for a moment and vanish again. The tide is forcing its way through the sands. Knee-deep at times, you squelch through sand and water to gain the stake-line, and well for you if the right side has been gained. Even then the shore has to be made at top speed. You might think that if 
a fowler was a good swimmer, surely, if the worst came, he could swim ashore on the tide. He might do this if the set of the inshore current did not exist; but it does, a belt of it a quarter of a mile in width; and this rushes and whirls at terrific speed along the shoreline, finally turning out to sea, banking up the sand-bar with its silt.

The strongest swimmer in that set of the tide would be washed away like a feather from a gull. Even seals and fish avoid these tideraces as much as possible. I have watched small fishing-craft for hours, under certain tidal influences, feeling their way up the tortuous channels; to all appearance it is open water, but a deviation on either side of little more than six feet meant grounding and the loss of the catch. Hideous death-traps they look when the tide is out, and that is just what they really are; like steep railway-cuttings, with water at the bottom in place of rails. I have been down some of them in a boat, and swum over others. But sometimes sharks have been captured there. They had followed the teeming shoals of various fish; one followed a shoal up a narrow creek and got stranded. If you would know what manner of a sea-monster can visit our shores, 
go to the South Kensington Natural History Museum, and look at the great shark there which was taken off Shanklin, in the Isle of Wight. Far more was heard about them in the past than there is at present. The shark is as cunning as a fox, and as ferocious as a tiger; but the great one alluded to above is harmless where men are concerned, though gruesome to look at.

If you wish to hear a perfect Babel of voices from the fowl, pull in a skiff just off a sand-flat, when they are feeding by moonlight, about one hour before the tide makes in. You will not be able to see much, for if thousands shoot over the flat surface, they only look like a smoke-cloud rushing along. But you will have something to remember. Never take a gun out in the skiff with you, lest you be tempted to fire towards shore, where the noise comes from, and might kill some fowler stretched out for a big shot, with his head only raised close to the tide. Also remember, if you are out for observation, to keep far enough out in your skiff, or some one firing from the shore seawards may kill, or at least seriously wound, you.

Moonlight, the soft full radiance of the harvest moon, falls on a peaceful God's Acre on 
one of our Surrey hills. So bright is it, that we can read the records of the departed on the tombstones. The old tower with its shingled spire glistens in the light that plays and lingers around the quaint porch, touching here and there, until at last a flood of light falls on the flagstones of the porch, silently showing the old oak door, iron-clamped and nail-studded, that guards the entrance to the House of God.

There, where old and young alike rest in peace until the dawn of the hereafter, on one stone, full in the light, we read:

"Come unto Me all ye that are weary, and I will give you rest."

All the pleasure of living, all the hopes and fears, the disappointments and bitterness of heart, will soon be over. This is a strange life, this life of ours; for if a man can barely know himself, search himself as he will, it is surely rashness on his part to judge others. The why and the wherefore of things we shall perhaps know when all that is mortal of us rests in peace there under the moonlight.

Just before the dawning of light all things 
rest ; a time of mystery this is, Nature keeping her own secrets. There are certain influences which, though felt by most, can never be explained. In one old-world district that I knew, where for generations no change had ever come, except in the usual course, the people held a traditional belief that just before the breaking of the day, when the last hour of the night is the darkest, Nature looks on, with hushed breath, at a struggle between the powers of Light and those of Darkness.

Those who love to study some of the problems which are so closely connected with ourselves will not smile at a belief such as this, childlike though it may seem. Nature may be studied in all places and at all times, but I have personally a special love for the calm of the night, and the hush, and for the silence of the snow. The popular idea is that night is lonesome, and the stillness of the snow without life: but this is far from being the case ; in the darkness and in the snow life stirs freely.

I have seen the night fall, and watched through it until the dawn of day, many a time, just to hear the voices of the night, and if matters should be favourable, perhaps to see some of the creatures that owned these voices. 
Stern puritanical teachings influenced the folks in our fishing village.

"'Tis a quiet night, Master Baxty."

"Ah, 'tis as you say, Reuben. Let's hope 'tis as quiet a one with our old neighbour, Ephraim Tranter, fur he's passin' away."

"Ah, well! I reckins as he wun't hev much to trouble him ; he's allus acted like a Christian, if he didn't talk about it, same as sum do."

"Acts and work is nothin', I tell ye; they awail nothin'! If he ain't one o' the elect, an' knows it, no matter what he've done or tried tu du, I tell ye things is desprit fur his soul's peace."

“I knows that's what you tells 'em over an' over again at your Bethel."

"Yes; an' will continue doin' so, fur 'tis God's truth."

"Do they believe ye, Baxty? 'cause I don't ; so good-night to ye."

It is something to be remembered as long as life lasts, that sight of a strong man, who had done his best to curb a passionate nature, passing away. This passionate nature had been mixed with kindly and generous impulses, and with many vain regrets for hot and hasty words let loose in the boiling heat of 
anger, against those he would have given his life to shield from harm.

Men who have neither feared nor cared for anything, taking refuge in a manly stoicism, have turned away, completely broken down at the sight of such a deathbed.

Yes, Ephraim Tranter was passing away; but those who had known him best could see that he was full of thought, and that his eyes rarely left the face of his wife, the only being on the face of God's earth, as he once had flashed out, who understood him, or from whom he would ask advice. Faults he might have had; but under a stern exterior was veiled a passionate love for his wife that was hers alone.

With loving eyes, that were yet tearless, she watched, for she knew his time was near, and she thanked God in her heart that she alone would see him go, and that none but herself would close his eyes. She had been a friend to him as well as a wife, self-reliant, ready to share in his struggle against the troubles that life brings. In his inward life, the world apart, she had from the first been his consoler and his guide.

Changes come when day breaks. Those who have watched by the dying know the 
sign that comes at dawn, the look which is seen but once on the face of the living. One of the watchers, a man who had carried his life in his hands many times, saw this great change, and with tears running down his cheeks, and a lump in his throat, he moved away; the others followed, and the husband and wife were left alone.

Then the dying man spoke. "I have asked my God to pardon me for all my sins. Once I spoke in my anger to you, wrongly. I asked your pardon, it was freely given, I ask it once again. For - I - am-going away-awayHome." The day broke for Ephraim on another world than this.

Daybreak on the foreshore, a leaden-grey waste of waters, and the beach of the same hue, only brighter in tone, streaked with huge outlines, black and indistinct, of piles driven in years ago-a more dreary look-out it would be difficult to imagine. The shores are lifeless; the fowl on the water are not yet ready to come in, and those which have been feeding by night inshore are not yet coming out.

It is fairly dark; then out on the eastern horizon a line of cold light shows. It is soon 
obscured, and all is dark as before. Púffs of wind come and go; then there is a whistle of it, and you can see, for the wind has sent the fog-bank drifting away out eastward. It is a cold, light-dirty, yellowish-grey fog that casts a weird look over the waters and the beach. Before we can fully see things, fowl suddenly appear as if by magic; widgeon and ducks are coming in : those long, dark lines shooting along over the water, well off shore, are probably dunbirds or pochards, making for some sheltered lonely creek best known to themselves.

A couple of birds shoot over at express speed, looking like half-gallon bottles with long necks ; they are a pair of red-throated divers, "sprat loons." Narrow and stiff as their wings appear to be, very few birds travel at a faster rate when fairly on the wing. In a line with the beach, out of gunshot-how they gauge the distance is a mystery-a mob of curlews are dashing up and down : a novice would certainly let drive at them, so very close do these birds appear to be; but not a single shot would reach them. Sanderlings and dunlins might be got, only they are barely worth a charge when other fowl are expected. Most people who live inland would think such a large bird as a swan 
would at any time be conspicuous on the water, but it is just the reverse. At night, or at early dawn, the great white bird, whether on the water or on the wing, looks little more than a grey shadow. Sometimes at daybreak it will be quite bright for a short time; then, without any warning, a raw, damp fog will come from somewhere and chill you to the very marrow. This is the time for a mouthful, or, it may be, a couple, of ague-mixture, or you will be down next day with the shaking fever.

All fowl are more or less bewildered at such times ; it seems to "crope" (bunch) them up, and take the heart out of them. You can hear them cry around and about, and hear the swish and whistle of their wings, but not a bird will you see. They are in the same plight; and if they could see you, they would not come so close.

"How's the night, captain?"

"East on, along shore; dark as pitch, and blowing great guns. Don't tell the women, poor souls! for some of their men are out, and they will come on the beach. I hope and trust that they've made port somewhere."

A dark night! dark above and dark below, and with it a storm. You could hear the rush 
and cut of the waves far out, and the crash of each foremost wave as it fell. For a few moments there would be a pause, as if some mighty wave had taken up all the others in its course and was bringing them in with it.

Hark! something is coming at racing speed! It sounds like the water rushing from a thousand sluice-gates. For one moment a black wall is seen crested with a line of light; it leans forward, trembles to a sudden mighty fall, and, with a deafening roar, the shattered, broken wave rushes up the beach.

"I will come on the beach; no man living shall keep me off it - stop me who dares! If I am but a girl, I am his wife, and Ned is out in this hell of waters."

"Listen to me, Polly, my lass. I'm his father, and here's his mother; you're not the only one as will miss him, if so be as he's missin' when the boats come home. Cheer up! he may be snug in port; leastways let's hope so. Come home with us, my lass; come home, and wait for the dawn."

As all left the beach for a time, the young wife reluctantly went with them; but directly it was light the whole community returned to it. There was wreckage enough, but not of the 
kind they sought for; what had come ashore was merely an old wreck washed out of the sands. Glasses were freely used, but, to their great relief, beyond the spit of the waves nothing could be seen tossing about.

Humorous incidents, as well as pathetic ones, take place. After a storm there are sure to be a few longshore prowlers who, without actually coming in contact with the authorities in uniform, run very close to doing so; in fact, if the chance offered, they, like the grey gulls, would not hesitate to pick anything up. That was the reason why the preventive men, the coastguards, patrolled that particular line of beach in such numbers.

"Stand, there! What have you got under your arm? Stand, I tell you, or-_ "

“ Oh, only one o' them ere cow-cabbiges, what the Dutch luggers lashes to their sprit for cabbige soup."

As the "cabbige" was of a very intoxicating nature, Wincher had to part with it, although generously offering to fight the officer any time he was out of uniform.

There is life in the dawn; you can feel it as you inhale it. No words can describe its subtle essence; it must be felt. 
After the wanderer has been out all night, and is fairly tired at last by the rough country, a balmy dawn revives him with a soft south wind, which comes direct from off the sea, passing through the hollows of the hills over the wooded weald, and from thence through and over a land of pines and of heather. Rising from my couch of moss and heath, I make for the highest point of the moor facing south, and there do I stand for a full hour, glad to be alive, and feeling fit for any number of miles.

Any lonely foreshore, where no houses are near, is a good place in which to study wild life ; especially if down-lands run through parts of the coast-line, as covert, short and stunted certainly, but still good covert of its kind, runs for miles close to the edge of the tide, and fur and feather make use of it. Reach your place of observation over the turf from inland, and "crope up" in the covert; if you prance gaily along the shingle, as certain blunderers do, all the creatures will leave the beach. Some folks say they "never see things like other people," but the fault is their own; they do not know how to look for them.

The wild rabbit, the "grey drummer" of 
southern districts, frequents the beach in numbers, to feed upon the sea-weeds; and the foxes come to look after the welfare of the drummers, and of the fish also, if the chance offers. By the way, that local name for the rabbit is very appropriate to him, for he does drum at times; while the hare certainly boxes, fair and hard. Get as near as you can ; crawl if necessary; in fact, do anything but show yourself; cut a furze tuft to stick in the ground to hide your face, and patiently watch. One heron at least is fishing, or rather he has been doing so, and something has upset him, and he is rasping out his troubles at a rare rate. As he rises, we can see a mob of hoodie crows set at him, half-a-dozen or so ; they mean him to turn the fish out of his pouch for their benefit. Rooks mob him in the same way, whenever they meet him; and it is a most interesting sight to see how the thieves get above and below the heron, and how he threshes on with his large wings through them all. How it will end this time is a matter for conjecture, as I lose sight of them; to lie stretched out on the turf, with chin resting on folded arms, limits a man's range of vision.

A couple of cobs beat up on the hunt; the 
young cobs, in their speckled plumage, are far more daring than the old birds, and, if possible, more voracious; that is, indeed, saying something.

The climbing power of the rabbit, like that of two very different creatures, the toad and the frog, is something considerable. It looks uncanny to see rabbits dotting about on the tops of weed-covered piles, where you would expect to see only gulls; but there they are, and there they will be at daybreak.

Grouse are credited with doing a lot of harm to the corn after it is cut and shocked; but the rabbit helps to the best of his ability. He will climb the shocks, and sit up like a squirrel to eat his fill of corn, wheat, oats, or of barley, as the case may be. As to the distance, only those who have seen his work, and caught him at it, can tell of his feats; he will climb up a large holly in hard weather. Facts are not always pleasant to meet with, but they are always stubborn things to question. When there is occasion for them to do so, the hare and the rabbit can, and do, swim well.

Daybreak in the heart of the woodlands. So light has it been throughout the warm night that the first rays of the dawn have not 
been noticed. The heave-jars have been silent for the last two hours, and the owls have left off their cat-like mewings; a couple are passing to and fro from glade to glade, for it is the hush of Nature keeps them silent. Surely a fairer sight was never to be seen in any woodland district, in or out of England, than the small hamlet at the foot of a bright green valley, with balsamic fir woods on either side of it. A lark rises from one of the fields near the hamlet, singing his morning song; clear and distinct as a silver bell, each note rings through the air. Sometimes this hailer of the dawn will not even wait for the night clouds to roll away. I have heard the skylark, not the woodlark, singing high up in the darkness at daybreak: from his altitude getting the first streaks of light in advance.

Quite recently, when out on the watch well concealed, I was amused to hear myself discussed as follows :-

"What's the meanin' on it? What do he stan' an' look at nothin' with that 'ere machine up on his nose? What do he be after?"

"He's a picter-maker. I've sin him afore; he's arter birds, an' talks to sum on 'em."

"Damned if I believe that." 
“But I tell ye I stood hid up, an' see him call one over his head. An' he carries crawlers in his weskit-pockets."

Rain at daybreak - a gentle rain, which after a time ceases, and then how clearly all things can be made out! The ducks, coots, moor-hens, and rails leave the lake for the grass lands of the Park in a great hurry. They know that the warm shower will bring the worms out in thousands, and that other creatures which cling to the under-side of the grass-blades for shelter can be easily picked off. Fish are rising in all directions; rings on rings glitter all over the surface of the water. Good trout are in the lake, and trout are not the only fish that rise; coarse fish, so called to distinguish them from the trout, will rise for food on the surface.

If I, and all those who are bent on entomological pursuits would look, like the birds, underneath the leaves, in damp weather, or when the insects are at rest, we should find ourselves gainers by so doing; and as for fur and feather, no better time can be chosen for the observation of them than daybreak; that is the only time when, if judicious precautions are observed, certain shy creatures can be seen 
for a short time. Morning, noon, or night, each hour has its own sights, when some creatures are resting, whilst others are in a state of activity. A good reason for early observations is, that night-creatures are on their way home, and those of the day are coming out, so that you have the chance of surprising both at daybreak.

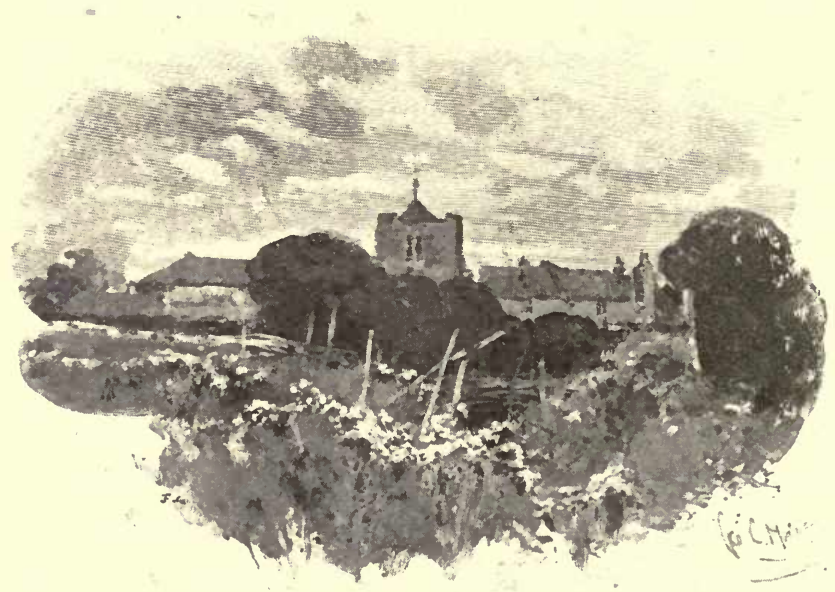


W I N T E R 



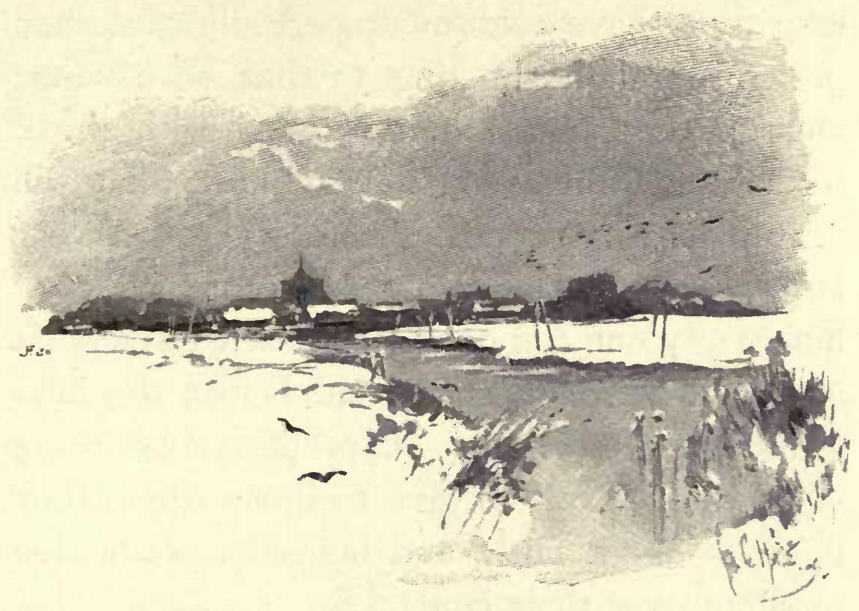

\section{IX}

ROUGH SHOOTING AND ROUGH SHOOTERS

UNDER the term of rough shooting I include the finding and killing of fur and feather, such as is not actually dealt with by the Game Laws Act. In past years-recently, comparatively speaking - this kind of shooting was carried on by men who professed to know no more about the creatures they sought than they saw with their own eyes.

Genuine sportsmen-who have gone home, 
long ago-have told me repeatedly that they preferred rough shooting to that of coverts; and on the point I quite agreed with them, for in the former you never know what will get up or what may run before you. A very large amount of quiet observation is necessary before any one can consider himself to be what is termed a rough shot; and before the laws were altered, owners of property, or those who rented it, would give to those whom they knew to shoot fairly and honestly, permission to shoot over their lands.

The granting of this favour brought its own reward. Many a pole-cat - and marsh-hawk also-was lost to the number of his mess, to say nothing about most valuable information given at times concerning a sluice that did not work well, or a weak spot in one of the dyke walls, by those who had been permitted to roam there, gun in hand. The only restriction was where hares and partridges were concerned. Some people would never shoot, if they wasted powder and shot by trying to shoot, for a lifetime; others take to a gun like a young duck does to water. The guns I am writing about - the old-fashioned muzzle-loaders-have their own peculiarities, only understood by their 
owners ; in fact, as killers, they could only be used by those who had no guides to rely on except their own keen observation. The lay of the land and the run of water had to be considered, also the varying kinds of vegetation.

Fieldfares and blackbirds are very numerous in and on the hedges at certain times and seasons; and these are now called schoolboys' game-birds. This may apply to the pursuit of them; but the bringing to bag, or, correctly speaking, pocket, is quite a different matter. You must be quick to wait on a shrieking blackbird when he dashes out of the hedge; and stalking fieldfares, unless they are starved out and torpid with cold, when it would be useless cruelty to shoot them, is a snare and delusion. Larks, again, require straight powder; and under certain subtle atmospheric changes, such as the grazing-flats are at times subject to, all objects, animate or inanimate, look double their real size. When shooting there under these conditions, I have missed what looked like fair shots, five times running, and others did the same. Once, I remember, after turning the matter over, it was agreed amongst us to take, for the sake of experiment, one or two sitting shots, although the lot of us-four 
all told-had qualms of conscience about the unsportsmanlike proceeding. The shots were taken, but not a feather was knocked out. Duffers, the lot! some of my readers may very naturally consider us to have been; but such was not the case, for there is a kind of distorting mirage that is hard to contend against.

To complete our discomfiture, a trip of ring dotterels flashed over the dyke-wall and settled on the flat. So close did they appear to be that we could make out their feathers, but not one bird stayed behind to the shots.

Others that we had spoken to on the subject, old veteran shooters, had had at various times similar experiences. There was a reason for it that not one of us could see at that time, although all is clear to us now. We called it then our bad luck, we had got out of bed the wrong leg first, and so forth.

By the edge of a rough meadow, too rough to turn a donkey into, where only burdocks, docks, thistles, and "torey" grass grow, a young fellow is listening most intently to some bird-note he has never heard before, and his prick-eared, bushy-tailed, fox-coloured dog, not larger than a marsh-hare, hears it also, and his 
bright brown eyes look up into his master's face. Corn-fields, hundreds of acres, reach down here to within half-a-mile of the tide. Birds are about, but they have not the least interest for the lad who is so intently listening; he has seen and heard all these before; but this cry is something new Very carefully does he examine the nipple of his single barrel, to see that the priming is well up; then he speaks to his dog: "You and I, Nip, must thresh this matter out. Come on. Steady, Nip, steady!" Weet-weet. Wit-wit-weet. Weet-wit-weet. "Steady, Nip, steady!" Then the bird-note ceases for a time, and, gliding in and out the tangle, more like a stoat than a dog, Nip tries to nose out the creature that "Weet-weet" proceeds from - at first without success.

"Hi-Nip, here!" and the intelligent creature at once comes to him. "It's a runner o' some sort, Nip-a sharp one, too; but we shall find him presently. You come and have a lap of water out of the pool. Now we'll go on another tack. $\mathrm{Hi}$, on! He's handy ; hark to him !" Weet-weet-weetweet-wit-wit-weet. Needles in bundles of hay are hard to find, we are told; and so are some kinds of birds. 
To and fro, quartering that rough ground in all directions, works the dog with unwearied patience. Then for one moment he is stationary. " $\mathrm{Hi}$, on! find him!" whispers his master. Once more Nip draws on, and then he stops dead at a thistle clump.

"Put him up!" and out shoots a quail that drops dead to the shot. A proud and happy fellow was that young shooter, for it was the first one that had been shot in that part of the country. "Bought wit is better than taught ;" what a man gains from unpleasant experiences he does not forget easily.

"Calling" was at one time very much resorted to by those who could do it well; but it was not the least use unless you had become perfect through practice; birds detect false notes instantly. In the case of plover, and some of the smaller waders, at times it answers well; but it is necessary to see the birds that the sounds, or calls, proceed from before you move on to where you suppose them to be. The calls of grey plovers and the golden, we have heard given with such accuracy by a rough shooter, hid up in the bents and shingle, that I have cautiously looked for the supposed birds. 
Part of a heavy charge hurtling over your head, as you are crawling up a bank to look over it, will shake your faith in trusting to bird-calls; unless, as we have stated, you have seen the creatures. Plovers are erratic at times, dashing here and there; and concealed shots are dangerous.

Thirty-two years have passed away, but even now, as I write, a feeling of general creepiness comes over me at the thought of a narrow escape I once had when out shooting. It is all very well for those who are not near, to theorise about the way in which certain fatal accidents take place, and how they might have been prevented; all takes place in reality so quickly that there is not time for thought, and there is a dead man, and a live one looking with wide-eyed horror down on him, in no time. It has happened, God only knows how, more than once in my own experience. If any one has not been well tutored, in the first instance, concerning the rules to be observed in general shooting, usually designated as rough, he had better carry a walking-stick than a gun. Very few ever recovered from those accidental shotwounds. It is, I know, the correct thing to sneer at the old Mantons, and others as famous; but 
these old guns hit hard, and sent their charges well home.

I have often wondered who it was that first talked of that simple theory of catching birds by placing salt on their tails. There must have been some keen satire behind this, originally.

The great charm about so-called rough shooting is this,- - you do not know what you are going to meet with, and some of the rarest specimens have been procured in broken ground. One man I knew well, when looking for rabbits on the dunes, put up some sandgrouse, and shot two. Another, when out for "lappers," shot a fine hoopoe; and so it goes on in the most contradictory manner. You may look after certain creatures for a long time, and not. find them ; then, when you have given the matter up, and are looking for other things, there they are in front of you.

One very great advantage about this kind of shooting is, that it gives a thorough knowledge of the creatures sought after. Vermin, both flying and running, require a great amount of getting at, especially on wide, open spaces; for if you can see them, they can see you. That word vermin, at the present time, has a wide 
meaning to it; once it had a more limited significance.

My own father fowled along the shore, not for profit, but for sport, and to see the ways of creatures. It was but natural that his son should do the same, and I have learned much by joining some of our rough shooters.

\section{"Beach her!"}

"Beach be damned! We're in the run o' the tide, an' past the shingle. Keep her to it; if any gear gits loose, Davy's Locker will box the lot of us. Hold on like grim death to a mainmast ; fur it u'll be one thing or t'other in quick sticks. Lash yer guns roun' the thwarts; fur if we has a chance, she's boun' to be half under water, cum what will. Look out, all! an' be ready fur the worst. Here's a bit o' beach."

That bit of beaching will never be forgotten by one, at least, of the party; for directly her nose grated on the shingle, out the lot jumped like cats, pulled her up, and there she had to lie for a couple of days, drawn up in the bents beyond high-water mark, until the weather smoothed a bit.

Fogs on low, sandy shores are the worst things to be out in. Sometimes the fog rests 
on the water; then for a time it will lift to the height of a man and fall again; and the worst of it is, all sounds are deadened by it. Some will keep the beach in all kinds of weather, unless the waves run high and drive them off it. Your cry of "Hail!" to a shooter, busy at work with some fowl that he can just make out floating close in-shore, will not go far; but if, not knowing you are near, he should fire in your direction, you are likely to find out that stray duck-shot reaches quite as far in foggy weather as it does in fine.

All kinds of shifts and expedients are necessary at times when in pursuit of fur or feather, and no one is more forced to make use of them, one and all, as occasion demands, than is our rough shooter. 


\section{$\mathrm{X}$}

\section{WOODCRAFT}

THE woodlanders and their families at one time, and that not very long ago, gained the whole of their living in and about the woods, at all times and seasons, by the practice of woodcraft : which term comprised timber-felling and planting, copse-cutting, hoop-making, or, as they termed it, hoop-shaving, hurdle-work, making plashed banks, and clearing out the wide dykes that ran at the foot of these, together with trug-making. Trugs are shallow wooden baskets or trays most cleverly made out of wood strips or laths - the wood of the ash is best for these-rounded at each end, with a half-hoop handle fixed in the centre to slip the arm through, or to hold by the hand, as the case may need. They range in size from those that would hold half a bushel to tiny trugs just large enough for a child to carry a root of primroses or a few wild flowers home in. In fact, it is 
for children that the smaller ones are made. Then there are hay-rakes to be made; also bakers' peals, skeps or straw bee-hives, brooms, threshing-flails. Last, but not least, charcoal burning had to be carried on. This is not a full list of their occupations, but it is sufficient for our purpose. A forester's wood-housequite as important to him as the house he lived in-was the workshop and tool-house, and in these, first with one and then with another of our friends, I used to have long chats when my own work for the day was over; so very interesting at times would the conversation be, that it had to be finished in the chimney-corner. That worthy and motherly old "dame," as her husband called her, where for some time I had my lodging, would send a gentle hint downstairs to us now and then- "Massy-oh-father, do give over, finish it another time." Then we would look gravely at each other, lay our pipes on one side, and retire.

In the wood-house, or, as they always called it, the "woodhus," there was a place for everything, and when not in use, things were where they should be. Axes for timber-felling and for lopping, each for the special purpose it was made for ; bill-hooks, large and small ; the beetle, 
and a set of wedges for wood-splitting; picks and shovels, garden-forks and draining-grafts, cross-cut saws and ordinary saws, rakes and hoes, were all there; to say nothing of a large rough open box of tools that to us would appear in wild disorder, but not so to the master. $\mathrm{He}$ would make a dive and get from it what he required at once.

From very early years the children, boys and girls, helped their parents to the best of their ability; for it was really a case of stern necessity. The natural result of this early discipline was simply this, that whereas town children are barely fit to be trusted out alone, the children of the woods are self-reliant, and can take care of themselves well. They are shy of strangers, these young dwellers under green leaves, but if you can once win their trust, and they know that what interests them has very great interest for you, they will talk freely and to the point. But you must know them well, and live with them, not for weeks or months, but, as it has been in my own case at different periods of my life, for years, in order to win their entire confidence.

"Now ain't that 'ere jist like what we told ye about?" they would say. 
"That it is, and I am very glad to see it."

This, by the way, might have been some mischief that a perfect monster of a hedgehog had been at, and they had fixed him securely, where they had found him at it, for me to see.

They would give us, by way of supper, a very hearty and substantial late dinner; for, as the dame tells you, she "makes bide-shift with a thumb piece, in the middle o' the day, and a sup o' summut, for she doan't care to cook fur herself, nor yit eat alone; she likes to see the whole roost on 'em goin' at it, hearty and strong ; it ain't no good cookin' else."

The master and his family are out all dayeven the youngest one of the lot-leaving the mother at home to provide for them, unless the eldest daughter takes the responsibility of deputy dame. They are strong, active lasses, all these woodland girls; plenty of exercise, fresh air, and plain living make them as active as deer. Some of them are runners so swift that it would take a good man to beat them. Rebellious spirits have been found in families from the earliest records handed down to us, and some, of course, there were in the families now under notice. 


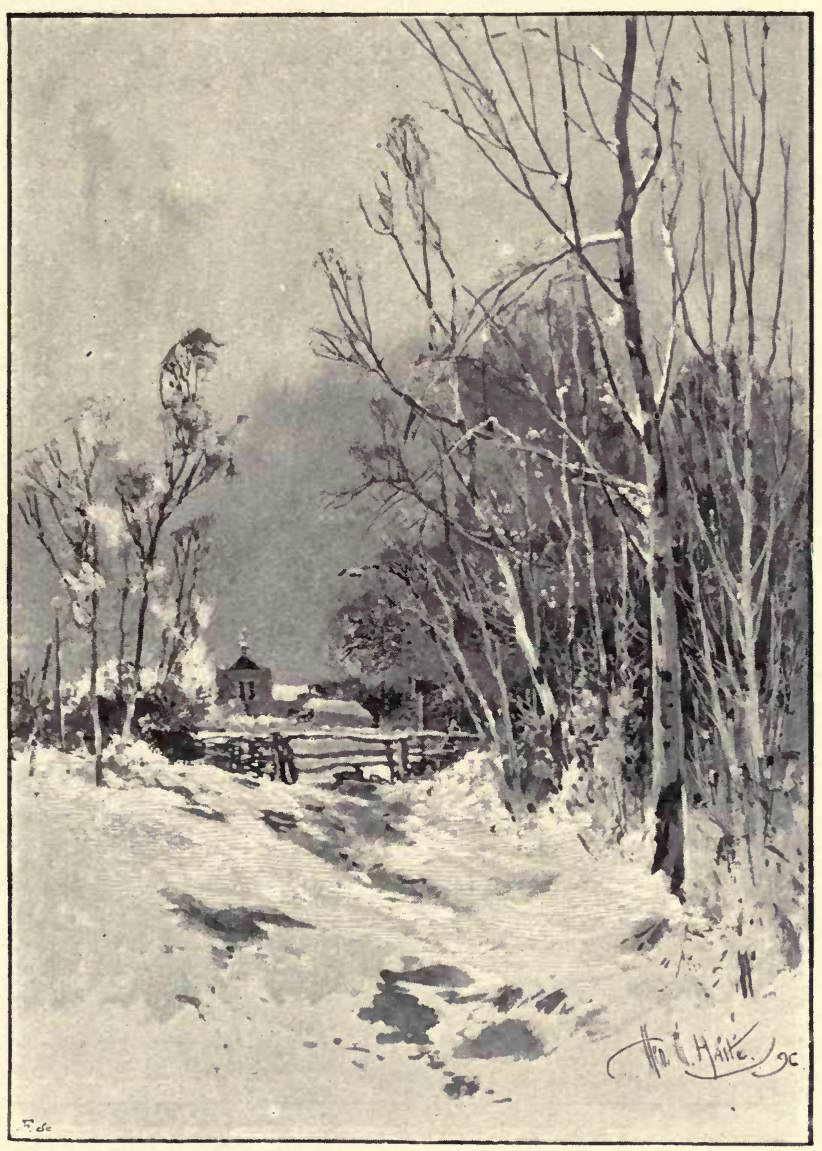

WINTER IN THE FIELDS. 

Taught to rely on their own wits, the younger members form opinions of their own, and proceed to act upon these, at times, quite in opposition to those in authority. But this does not last long. I have seen one of these elder sisters, who was acting in mother's place, after finding gentle pleadings all in vain, take up a small, sharp bill-hook, cut a nice ground-ash plant, and trim it up in a very quick and business-like manner. Then the offender would bolt off like a rabbit at top speed, all to no purpose, for, double and dart as he would, capture was certain. Then for a short time a voice in bitter lamentation might be heard. Sparing the rod was not a part of their creed. "Adder ile" was, and is now, considered a rare remedy for bites; but, for a good all-round remedy, one that is easily administered to those that require it, and one that has lasting beneficial effects, commend me to the oil of the ash-plant.

Slight differences will arise at times, even in the course of woodland courtship-at least they did in my own time. Some of the lasses I knew could throw, not only very strong, but very straight. One couple I remember had agreed to differ a little, and, in a huff, the 
swain remarked that "he'd had enough chouter, an' he should goo." When he had got about forty yards away, something caught him in between the shoulders "whack." It was a very fair-sized potato, sent after him by the lass he was "coortin'." And some others -they are elderly now-would, when they were mothers of families, hustle, as they called it, any intruder out of their gardens in fine style with the first thing that was handy, stone or stick; for in that lonely bit of country, folks had often to protect themselves.

Walking, as they do, in the course of their lives, all over the districts, far and near, of their quiet country, or, at least, the greater portion of them, they naturally know where the abiding-places of creatures are. Wild things hide for a time just to see if the noise they hear in the woods and thickets will bring them harm; but, satisfied on that point, they take little notice. In fact, the less timid will draw round at meal-times for scraps of food from some of the men who camp out in the woods.

Building a shanty does not take long. A young fir is cut and trimmed; this is held up at each end by a couple of stout posts, forked 
at the ends; light poles are stuck into the ground and fixed to the pole on either side, then thatched with heather broom, fir boughs, or fern-in fact, with anything that is handy. A couple of rough thatched wattle-hurdles do duty for doors at either end.

For bedding fir branches are used for the first layer-small ones, of course ; then heather or fern as a luxury; and if you are near a bog swamp-and there is sure to be one not far away-a sheaf or two of tussock-grass is littered down on the top of that. The campkettle is slung, a trench dug to carry off the water if it rains, and there you are. I speak from happy experience, for some of my staunchest allies in past times were woodmen. "Snacks" were the order of the day, substantial ones for breakfast and dinner; but the evening was the time for a square meal. One would be told off to get ready for the others, and there was sure to be lots of tea, strong and well sweetened, freshly made. Then savoury frizzles done over the wood embers would make their appearance, and hot baked potatoes were done to a turn. There is nothing like work in the life-giving scent of the woods for creating healthy appetites. 
The evening meal over, our pipes would be lit, and conversation become general on the one topic that had interest for us all: namely, woodcraft. Presently, talk flagging a little, it was voted we should go to roost; simply taking our shoes off and lying down with coat or jacket over our shoulders. In ten minutes the woodmen are fast asleep; but the novelty of it all will not let the new-comer close his eyes, for he hears round about him and over his head the voices of the night: Something rustles over the thatch, jumps off it, and you hear the squeak which proceeds trom a woodmouse that is being chevied by a weasel. Then from the trees overhead comes a low crooning twitter, and snap-snap-snap from a brown owl that has just made a very satisfactory meal, or, at least, part of one.

When at last you find that you are, in spite of your strange surroundings, dozing off, something comes rustling and poking close outside the shanty. It is a hedgehog, no doubt attracted by the few fragments of the late savoury frizzles that have been thrown out in the grass. Unless a fire is actually needed in the evening, it is damped out, for reptiles of some kind would be sure to make for it. They will 
follow up a current of warm air by day or night. Very rarely are the beds in a shanty allowed to remain over a couple of nights without being moved out, for snakes and lizards must be kept from trying to share the apartment. By some means or other, all our friends escaped mishaps, although some have had very " narrow squeaks," as they put it, from crawlers.

Eggs and bacon form the staple dish of wood-cookery, for they take small time to get ready. It is wonderful at times, under certain atmospheric conditions, how far the scent of this dish will travel. Attempts have been made to find out if wild things are affected by this. As far as I have been able to judge, wild ducks do not like it at all; they are up and off at once. On the other hand, a few small deer are certainly attracted by it.

One of the most startling experiences when sleeping out is to hear the cry of a fox almost close to your ear. Reynard at times, in the dead of night, will pay a visit. He may have visions of a hen-roost, but when he slips by or round our shanty, as the case may be, his sensitive nose tells him at once that his arch-enemy man is there, within a 
foot of him; then he will for a moment yell out in terror as he rushes away. This has happened more than once when I have been camping in the woods.

Much fuss has been made at times about the influence exerted by some people over different animals and birds ; yet this is one of the secrets of woodcraft gained by watching the creatures and making yourself acquainted with some of their weak points. Kindness, patience, and firmness will do much, but not all. Giving them dainties in the shape of food is the real key to the secret.

Why should creatures risk their lives at times to come into gardens from the woods and the fields in the most reckless manner. It is not hunger causes them to do this in the bright summer-time, but their fastidious taste and liking for the very best that man has raised and watched for his own use. If the haunts of the creatures are known, what is to prevent a kind of keep-your-distance sort of acquaintance from being made to begin with? If you are wise enough to take some of their favourite luxuries there to them, so that they can enjoy their treat in peace, be very sure that what they have found one day there they will look for it 
on another, and before long they will look for it at a certain time; and not only that, but they will watch, all unseen, for the creature that brings it to them, until at last they will feed around you. This seems simple enough, but then you must wear the same suit every day and keep quiet, which is essential to success.

Our friends the woodmen have had strange company at meal times in the heart of the woods, for on all large estates certain parts are set on one side as sanctuaries, and they are not disturbed by being shot over or through. In such places squirrels and mice will come for crumbs, and the robin perches by the side of the men.

I had a similar experience myself once. Let any creature know that it is safe when you are about, and that you will not try to harm it, and the rest is comparatively easy. There are exceptions to this, I know ; for some creatures are as wary, where they have never been persecuted or interfered with in any way, as those that have had a rough time of it. The reason for this has not yet been explained, and I do not think it ever will be.

Weather changes have much to do with the movements of all creatures, wild or domes$\mathrm{R}$ * 
ticated. To be weatherwise, as the old folks have it, is one part of woodcraft; the study of the weather is a really earnest one, and it is made to some purpose.

"Have you done bark-stripping, Tom?" I ask, as my old friend comes along with his tools.

"Well I be, fur a time; the wind be shifted dead eastward. I told my dame as we should hev' a orkard change afore long, fur the blackcocks shifted over to t'other hills. The bark wunt run now, for the sap hev' gone down agin, so I shell hev' to wait till the weather gits kind agin. 'Tis a pity; we made a good start like." A change of weather such as this seriously upsets flaying arrangements.

My readers may think us a little old fashioned in our opinions, but when I lived with the seafaring folks we put more faith in their weather forecasts than we did in weather glasses. Very often have I met them early in the morning passing through the woods or over the moors, and have asked their opinion about the weather; for changes come quickly at times where a long line of hills is well wooded. You may watch the clouds gather and sail up from open water, miles 
away, either from the south or west; they are high up, passing swiftly over the weald. When they are over the hill-tops, something seems to attract them, and you will see the cloud-masses lower and hover round for a time. Then comes the rain, sheets of it; and for a time the face of the country is blotted out. But it soon clears and the sun comes out, the vapour clouds passing away into space. I have known it rain in the summer time more or less for a week on the hills, while in the long vales, only seven miles away, there has not been enough rainfall to lay the dust. The air-currents that draw through the hollows are very shifting; conflicting waves of air appear to meet at times, to judge from the sudden changes from heat to cold. When frequent, these sudden changes affect people not a little.

"Will it be fine to-day?" I asked one of them that I met, for on that particular day much depended for me on its turning out fine, and I was anxious about the matter.

"Did ye see the rooks makin' for the ship (sheep) walk on top o' the hills?"

"Yes, and there was a lot of sky-tumbling going on with them." 
“ Did they cackle an' talk to the'rselves when you see 'em tumble?"

“They did."

“Ah! I reckined so."

"The mist clouds are rolling up, and it is bright above ; below it looks fair."

“' I know it do, but ye see the looks o' things, an' fur that matter the looks o' some people, ain't tu be counted on. Did ye notice if them 'ere mist clouds, as you call 'em, clear that big holler in the hill or hang over it ?"

"Some of them not only hung over it, but seemed to drop down into it."

"Well, if you has eny 'tickler thing in hand, I should 'vise ye fur to set it by, fur to-day. Afore twelve o'clock you'll find the rain tumble down middlin' thick."

It did so to my sorrow.

The woodmen know the time when the first migrants arrive, and when they depart. Some of the birds are seen to alight dead beat, others are only heard on their departure ; the movements of the migrants that are leaving us are more open, for they gather before flighting.

From a man who was getting stones from the moor for house-building I found out where 
the ring-ouzels pitched for a time in the juniper bushes. Finding that the matter interested $\mathrm{me}$, in his plain manly way he gave his observations about them and their ways. Before that time I did not know that at certain times and seasons the white-throated blackbird, as he is named, could be seen on the moors in the heart of Surrey. They used to come and go without being molested at that time.

"Where we gits the fust wilets, white 'uns an' blue 'uns, an' the fust primroses, that's where we sees them 'ere little hay-builders, afore we gits a glint on 'em anywhere else"chiff-chaffs and willow wrens the boy meant"fur it's loo there. And," he added, in a much lower key, "that's the place where we gits adders, big 'uns, afore some folks fancies they're out o' their holes. We'll show ye."

The kindness and care for our well-being shown by the youngsters who gave me the above information I am not likely to forget.

"Cum on, Bill an' me hev' got our forked sticks," they said one day. "Keep yer eyes open, an' where you sees wilets, you look out fur adders on this 'ere sunshiny bank."

Looking right over their heads, as they were going on in front, I spied a fine specimen that 
would very soon have introduced a vicious brood into the world. The reptile was not coiled up, but stretched out and flattened, thoroughly enjoying the hot sun; for it was hot for the time of year.

Before the boys knew exactly what had really taken place, I was standing in front of them with the now furious, hissing reptile securely held with my thumb and finger just below the head, our only method of capture We have had little practice at that work of late years, I am sorry to say; but if the chance offered, I think I could do it again.

Strangely enough, I was not invited after this to "come on" any more, for I was credited with a particular kind of knowledge that I certainly did not possess; one gained from the powers of evil.

The people that have for generations lived by the various employments comprised under the name of woodcraft are fast passing away, and their surroundings also. This is to be regretted, but there is no help for it. Their sons and daughters now speak of their early days as belonging to a past that will never come back, and, indeed, in their hearts I fear they do not regret the old state of things. 
As it is on some of our once remote coastlines, so it is now in the heart of the woodlands, and races once distinct, with all their virtues and faults - if exclusiveness and plain speaking are considered to be faults-have, I believe, at the present time, by the force of circumstances, got merged into other elements and have almost passed away. 


\section{$\mathrm{XI}$}

OLD RECOLLECTIONS

THE shooting garb - the outfit generallywhich was given in the beautiful picture lately published in Black and White of "Chantrey's Famous Shot," was that worn in my boyhood's days. I remember, indeed, being in the same rig-out myself ; tortured by high-standing shirt collars, which were starched into a ferocious stiffness. A man could not hang his head, with such supports to his cheeks, if he tried to. Yet they burned straight powder in those days!

Our uplands, the corn and root fields, as well as the grazing flats of our North Kent marshlands, fairly teemed with hares, partridges, and fowl. Rabbits were hunted as if they were tigers; that was on account of the serious harm they did by burrowing into and injuring our dyke banks. Yet, in spite of their abundance, the game was as free from shot or 264 
snare as are the creatures in the Zoological Gardens.

The farmers and the graziers, or stockbreeders, formed two very distinct classesor, as one should perhaps rather put it, their callings were quite distinct, the farmers buying all their stock from the graziers. Both held their lands from one generation to another, and they were served by those whose parents had served their own, and were looked on as trusted friends rather than servants. The children of master and of man played and grew up almost side by side. These farmhands and the "lookers," or guardians of the dykes -an important post in marshlands-made common cause in the interests of their masters. All knew their own boundaries, and their rights were very jealously guarded.

One of my farming friends had long been at daggers-drawn with a marsh grazier, the point at dispute being a fence that divided a certain path. A fine fellow was the former, and one who usually spoke good English; but, under the influence of emotion or excitement, he dropped into the dialect of our marsh folks. When he was near his end he said, "How fur hev' I got tu sail afore I anchor in port, 
doctor? Let's hev' it straight, an' no beatin' about the bush. Shell I git up agin?"

"No."

"Ah, well! On yer road home call on old $\mathrm{C}$ _- We bin up agin one another fur the last fifteen years. I should like to shake hands with him afore I go, jest to let him know as we can start fair an' square when we meet agin."

Owing to the favourable surroundings, partridges were very numerous. Never elsewhere have I seen so many as I have seen in those large fields, where the stubbles reached up to the shooter's knees. As the birds were fairly shot, over dogs, during the whole of the season, there was no marked diminution visible in their numbers. If the stubbles were shot over, the root crops were not interfered with; sanctuary was allowed the birds, and the shooters profited by giving this.

One old friend of mine shot at times from the back of his rough-coated white pony, a creature that was almost as deliberate and thoughtful as his master. This was the only purpose for which he was used, and no one but his master would the animal permit to make use of him in that fashion. If "Skip- 
Jack's" services were required, it was no use for one of the farm-hands to go into his paddock for him. He might try to lure him with the sieve half filled with oats; all the old pony would do was to kick at the proffered dainty, and to tear all over his small domain. If, however, his good old master entered with his gun under his arm, and "Don," the fine, double-nosed Spanish pointer, with him, "Skip" knew that he was going probably to have a good time of it, and he would walk up, rub his nose against the old gentleman, then snort and take a good sniff at "Don"; a pretty sight it was. Then, all being ready, they started for one of the stubble fields, a young acquaintance of my own, who held the post of "sparrow-shooter," running in advance to open the field gates, and to carry the game in the net game-bag. This youngster knew well where the coveys fed, rested, and jugged for the night; but this knowledge was, as a rule, discreetly kept to himself.

Directly the stubbles are entered, Skip-Jack becomes transformed, his eyes are on the pointer at work, and he follows for the point, all without a single word from the keen shot who is seated 
on his back to guide him. The dog points, a dead full point, and the pony stands like a rock. The birds rise, and a brace drops right and left, clean killed. Three brace are in the bag ; then they leave the stubbles, just top the old hedge that surrounds the field, and drop into the rushy meadow that joins it. Luncheon time comes round, and the sparrow-shooter shares fully in the feast. Master Skip-Jack receives a few lumps of loaf-sugar-a luxury which he highly appreciates-from the hand of his master.

Then they pass from the field into the meadow, where the broken covey has taken refuge. Here they are picked up; one, and again a brace of them. The shooter bids the boy count. "Eight brace, master; all good 'uns," is the result given. "That will do, boy ; that will do. Now we will get back home."

"Cock are boring in the alder run ; I'm goin' down early after dinner. The dims come soon now. Coming, ain't ye?"

"Yes, I'll come, but I shan't shoot. I'll keep well back and look on."

The latter part of November 1872 had been what the rustic population called "a bit wild." Rain and high winds had been followed by 
a few sharp frosts. Leaves had been blown through the woods in heaps to settle for a time, then to go whirling away elsewhere. The whole of the woodlands were drenched; windthreshed and sodden. The alder run, as it was called, consisted of some trickling trout streams that ran through a sheltered copse of fine alder trees. As the rains had flooded the large ponds, their hatches had been raised to let off the surplus water, thus lowering the water in the run, so that margins of peaty mud offered excellent boring for cocks. As this was fortunately not swamped land, you could get about without fear. A more dreary place you could not imagine, shaded as it was by the leafless trees, that covered the hills on either side of it. Great masses of storm-clouds hung over the scene. From the borings and mutings on the mud and in it you saw it suited the cocks to perfection.

Whiss - whiss - whiss! up he shoots, and “Mark-cock!" escapes from one's lips involuntarily, the sporting instinct being strong within.

A clean miss from our friend-so clean, that no excuse could be made for it. Quark! switswit, quark! and away shoots a mallard, but 
not far. The shot rings out, and he lets his neck loose, coming down with a splash, to be half-buried in the soft peat mud of the run.

Only recently I have seen the assertion made that cock do not feed by day. That I contradict; for, under certain favourable conditions of the weather, they do. A woodcock, when boring on "softs," shows a very conspicuous mark when he flirts his tail up; as does the moorhen.

The first cock, as I said above, was missed clean, but the second, put up from his borings in fairly open ground, was dropped in his tracks in fine form.

One fine mallard and a cock represented the bag for one very unpleasant afternoon, in which three took part, my old friend, my humble self, and one of the best water-dogs that ever brought a duck out of the water. From the fuss our friend made over Scolopax Rusticola, there must be some strange fascination about that bird; the fine mallard he hardly reckoned as worth picking up.

Keepers, as a class, have had much abuse heaped upon them; yet the English keeper is a product of our soil, generally worthy of it ; and I have known some of the finest of these 
guarding with their under-keepers estates which were situated on the border lines of four counties, where lived degenerated descendants of nomads - who inherited their parents' vices, without many of their wild virtues-owning only one lord, the Lord of Misrule. Man to man, the keepers and the poachers met many a time, and fought the matter out under the forest trees, both being afterwards cared for by the same medical men. When rough work was expected at night, the doctors of that district slept with "one eye open." Independently of the position of high trust which they held, they valued most highly the confidence of the gentlemen whose covers and fields they guarded. We are many of us familiar with that typical portrait which a famous artist presented to its original the keeper, who is depicted as taking a pheasant from the mouth of his noted retriever. The artist, depend upon it, respected that man.

And the masters of that day, large gamepreservers and sportsmen, were not easy men to deal with. They rode as straight to hounds as they looked down their doubles when the partridges whirred from the stubbles, or the pheasants went rocketing and chouk-chouking 
over the tree-tops; men of their inches, who could use both hands well.

" I'll come with you to-night, $\mathrm{K} \longrightarrow$, and if I have the luck to fall in with the leader of that gang of ruffians, leave him to me, and let the best man win."

"Squire-squire-pardon me for saying it, -but don't come. Think of the mistress, and your young sons. Not only that, think for the whole estate. It will be worse if you do come ; all the lot of us will have our hearts in our mouths, thinking about you ; and we shall fight half-hearted."

"You're a nice wet blanket, stopping the fun; but, looking at it from your point of view, I may as well sit up in the gun-room and wait for prisoners."

"If we do get the leader without hurting him, we'll bring him to you, squire; then you can have it out with him, in good style, give and take, with the lot of us there to see fair play."

The leader was brought in, and four men with him, but he was in too dilapidated a condition to require any more rib-binders and upper cuts; he had got his whack, so had the others. Some of the keepers were slightly 
turnip-headed, decidedly puffed about their craniums, and two of them had developed noses of the strawberry pottle type.

Referring to the time of my boyhood, I cannot speak with patience of the puritanical, Calvinistic teaching to which we were subjected. People of the present day cannot realise the hard, iron-bound superstitious creed, the terrible teachings which children, scarcely more than infants, were subjected to from the socalled elect. Such merciful, loving words as "Suffer the little children to come unto Me," and the words of pardon and comfort, "Neither do I condemn thee; go, and sin no more," were never repeated, to my knowledge, in my childhood's days. Ours was a grim creed, based on the narrowest of lines. The letter of the law and its thunderings were preached with extreme unction. But through that cursed creed I have myself seen the face of more than one young woman, showing upcalm enough then, God knows-through the quiet, deep water where rest had been sought.

For six years the young sons and daughters of one of the sternest head-keepers I have ever known were my constant daily companions. We had strict orders as to where we might $\mathrm{S}$ * 
and where we might not go, and I never knew him to be disobeyed. Something in that man's voice and bearing kept the most daring youngster from dreaming of disobedience.

No trophies adorned the gable-end of his large, ivy-covered cottage; and so quiet was the place, so free from disturbance, that we have watched the green woodpeckers-wariest of birds-playing about the trunks of the decayed trees near his house, with all the confidence of titmice; such a sight as I can never hope to see again.

The ravens nested and brought out their young unharried by him. But orders were at last given, or at any rate desires were so strongly expressed, that they could not be ignored; and the ravens, being consequently robbed of their young, with their proverbial sagacity, left that neighbourhood, and found for themselves a new home in Sussex. I believe I saw the very last one that was in Surrey.

I once heard a large preserver of game say to a keeper he had engaged, "No one comes between you and me. You are responsible for the carrying out of my orders, and from no one but myself will you receive any. I shall 
not give you impracticable orders, but those that you do receive, you will carry out to the letter."

This estate, like others near it, was alive with winged and ground game, and the waters were full of fine fish. The public were allowed to roam freely over them, the home coverts alone excepted. Yet they lost nothing by this - not even a little, rat-sized, scuttling rabbit. If certain gentlemen had not taken the matter up for the good of the people, some of their breathing-grounds would have been lost to them for ever.

It seems to me that much of the useful as well as the beautiful has been "improved" away.

Our old farmers understood what they were about when they kept the grand old hedges in order, the hedges that afforded shelter; keeping the fields and the stock "in the loo." They protected their buildings, too, by woods and copse-growth. The low, rambling buildings had huge chimneys and thickly thatched roofs. The vegetable gardens and old orchards closed them in also, and in many cases only the thin blue wood-smoke curling up above the tree-tops betrayed their whereabouts. East winds and the keen nor'-easters upset stock in 
the same way that they do common humanity; the unkind air-currents rough the beasts up when out at feed, causing their coats to "stare," as it is termed. By opening one of the solid gates in the hedge, outlets set here and there, the stock were at once in the loo and in comfort, whatever came.

But I have lived to see rows of fine old elms, which formerly shaded green lanes on either side-where the whole stock of a farm, pigs included, could loiter away through a long summer's day, so well contented with the cool, sheltered retreat that the stock-boy and his grey bob-tailed dog could doze and sleep, wake and doze again, having nothing whatever to do -ruthlessly cut down for no earthly purpose. Yet shelter, above all things, with food, is imperatively necessary for man and beast, as those old tillers of the soil knew when they guarded and tended with religious care the trees and hedges which their forefathers had planted.

An old rustic said to me lately, "This 'ere farm wus a loo place one time; you knows how stock an' craps did sort o' kindly in the old days, when you wus 'bout here. Now, when the wind blows, 'tis enough to cut yer ears off. It 'ud shave the smellers off of a mouse." 
Those rugged guardians of the fields that kept draughts of blight from the crops, and nipping frosts from doing mischief at critical periods, are gone, never to be replaced.

One old farm I recall to mind, which was tenanted and worked by a near relative of my own. The farm hands, being all of them, at the time I allude to, men of middle age, and married, did not live in the house.

From time to time, as life has worn on, I have revisited that farmstead, often making long stays there, in the lonely but beautiful old dwelling. By long visits I mean, long for one like myself; for, like my favourite wader, the green sandpiper, I am continually on the move, never long in one place.

The roof was tiled, and thatched over that, thatch on thatch, not because the under stuff had got rotten, but to begin with. The result was, that the house was cool in summer, and warm in winter. The thatch was nearly three feet in thickness, and it projected so far over the outer walls that you could shelter from rain under the hospitable-looking eaves, which were tunnelled by flocks of sparrows in the same way that a sandbank is by the sand-martins. The windows were, of course, all of them, quarry lights 
and casements. In front, running the whole length of the house, were the straw bee-hives, in the shape of inverted extinguishers of the ancient type, each hive on its own stool. Hives and stools were made entirely by my handy kinsman. A thick border of Londonpride edged the narrow garden path, and within it great clumps of variously coloured sweet-williams stood, with splendid cloves. The carnations of modern days would hardly beat those in that old garden. Between each hive, rods of white lilies reared their stately heads. When the windows of the low, cool living-room were set open, the life-giving odour from those old-fashioned flower-borders filled the house, from basement to bedrooms. Lupins, heartsease, stocks, and mimula-mimelusses they called them-with the single and double marigold, made up the brave show.

As to the fruit-trees, there were ribstonepippins, Blenheim - oranges, golden-pippins, choice codlins, and russets. Near the well, with its moss-covered bucket, stood one of the finest amber-heart cherry-trees that I have ever seen. The well itself was shaded over by a well-grown Orleans plum-tree, which cropped so heavily that the drooping branches 
had to be propped up with light forked stakes. When the sun-burnt toilers of the fields came to fill their kettles with the cool well-water, they did not go back empty-handed. I have seen the master and his wife fill the children's pinafores with fruit, and load the mothers' arms with onions and lettuce. Things went smoother in those days, methinks-in some of the smaller matters, any way.

No paint had ever been applied to any part of that old house, neither inside nor outside. When it was first built, the whole of the woodwork received five or six coats of pure linseedoil, until the wood-well-seasoned oak it was - could absorb no more. Perhaps some of my readers understand the great preservative power of such treatment; it lasts for centuries. The interior was whitewashed-ceilings, beams, and walls, a pure white; no broken tones of distemper, that cult term for honest wash. The white was relieved by the rich tawny brown of the doors and the furniture. Clock-case, dresser with its wealth of pewter and quaint crockery, together with the tables, kneadingtrough, and the solid chairs, were all of the same rich hue.

About the large, airy bedrooms there was 
a Spartan-like simplicity. You could, as they say, have eaten a meal from those bare floors as well as from a well-scoured wooden trencher. Wood-ash lye was used for the scouring of them. There stood the large four-post beds, with their spotless hangings and lavenderscented sheets; one chair and a chest for clothes completed the fittings of each chamber; only in that of the mistress were the refined luxuries of a washstand and swing lookingglass. The master and myself were satisfied with a sluice-down over the kitchen sink, and a polish up with the clean but coarse jacktowel, putting the finishing strokes to our toilet in front of a bit of broken looking-glass fixed up to the wall with nails.

There was a bacon-loft in the great livingroom chimney, with its wide hearth, and the snug settles on either side of the fire. At certain times the embers were cleared off the hearth-stone, and the bacon-loft was inspected to see how the flitches, chines, hams, and cheeks were getting on; and last, but not least, those long, delicious farm-made and smoked sausages. Oh, the hearty fun of it all, going up the short chimney-ladder, with a round cowgown on, into the drying-room! The acrid 
odour from the wood-smoke made your eyes run and caused some sneezing; but the pleasures of anticipation of the share in those good things which would presently be yours, made the review of all that was hanging there a delightful task to a wanderer like myself, coming to revisit good old kinsfolk.

When the season of the hoodies, the duncrows' visits to the upland sheep-walks, came round, the luxuries of the drying-loft were neglected in favour of hoody-crow pie or pudding. Just before this you would see the farmer touching the locks of his flint doubleManton very carefully with the tips of a feather that had been dipped in the finest oil. $\mathrm{He}$ got his crows, wary though the birds are, hung them for the proper time, plucked and prepared them himself. Then they were handed over to "Mother" to deal with. Crow-pudding was a dainty, he considered, with the thin rashers of bacon inside. Yet his wife and I always declined to join in that feast; we had our prejudices. I know one thing: when he had eaten the whole of a crow pudding, and washed it down with a full tumbler of "Mother's" old mead, he wore an air of supreme satisfaction. 
Many a bit of old-time wisdom have I had from his lips during the long winter evenings. A hobby of his was the cutting, seasoning, and shaping of walking-sticks-staffs that you could rely on- of ash, crab, blackthorn, whitethorn, and oak, well handled. A large sheaf of them he had, and of each stick he would give you the history. Several of those I have worn down short, and they are all kept to look at, as silent, trusty servants that have, at a pinch, served me well.

The library consisted of a large-typed Bible and a few books, chiefly of a serious nature, and they did not wish for more. And on the white walls of the sitting-room were hung three pictures in black frames, one painted by my father, a gift from him, and the other two by myself.

Long years have passed; the good old couple are at rest, and the old house is down, and the lands once tilled are now used for other purposes.

Speaking of those pictures, as a boy I hunted for all odd scraps of animals, birds, fishes, reptiles, and insects that I could lay hands on, and in all likely quarters. Kind friends also aided me in the quest; and valuable works 
were often to be cheaply bought at the sales of well-to-do residents in our rambling fishing village. Old books, furniture, and engravings were not routed out so eagerly by town agents as they now are. If I had some of that old stuff by me that we once saved from various wreckage, I should be rich in a sense. All that I now own is a treatise on Falconry, date I633; some old engravings and etchings, and a wonderful article on the Woodcock by "a Woodcock Shooter." No name or initials give any idea of the standing of the author, but every line tells of minute observations of the bird in its own haunts, before drain-pipes killed off fowl.

That pamphlet is before me now, its leaves dog-eared and yellow with age, written, as it was, before I was born; and I have to confess that, with all my own personal observations, made for many years in localities most suited to the woodcock's well-being, I have not been able to lay one fresh fact before the public concerning that wide-awake, full-eyed bird.

The nesting haunts of some of our species are difficult to explore even under the most favourable circumstances, and some of them 
can be reached only under certain conditions of weather and tide. Redshanks and snipes are said to be common birds by would-be ornithologists, one or two of whom, I dare venture to affirm, have never seen either the birds or their nests in a natural state.

After a lifelong observation, I have only met with the birds above-mentioned twice where they were nesting; and in each case it was under exceptional circumstances and quite by accident. In one case I almost placed my foot upon one of the sitting birds. Yet I was well aware that dozens of them were about, and I knew that the greater part of them were breeding somewhere, and close enough at hand, too. But either of these birds, if a human form is seen near their haunts, will pitch down thirty, and even fifty, yards away from its nest, running through the bents, rushes, or blite to it like a rat. If there were only the birds to look after, the matter would not be so difficult; but you have to look after your own safety as well, the spots that they select being so dangerous that if you did make a mistake once, the chances are that you would never make another. So far as my own visits are concerned to those haunts which I have 
in my mind as I now write, I could not repeat them if I wished; those narrow beds of saltooze stripes, with the deep cuts on either side, through which the tide rushed like the waters from a sluice, have been solid grazing grounds for years past. Those long, grey mud-flats, patched and chequered by the wiry growth of the salts, were not very cheering sights, with screeds and drifts of cold drizzling rain moving about as they were caught by the cats-paws of wind. Something about it all chills and deadens you, producing a most weird and uncanny feeling, which even the best "ague mixture," pure and undiluted, will not move. The birds one came to see-their nests possibly also; but the chance of seeing the birds, even through the cold, mist-like rain, is small enough. Under conditions such as these it chanced that, on a dismal walk home through the rain, from a bent tussock about the size of a footstool, against which I kicked my foot, not ten yards from the spot on which I had been standing for some time, up rose one of the very birds I had come so far to see, and from a clutch of unset eggs.

Tons of the best and freshest fish were 
laid on our lands for manure at times; fish, indeed, were taken there in vast profusion; and I have seen at times a whale or a shark get stranded in the shallows through rushing them when following up the shoals. But the seals never came to grief. Our old fishermen seemed to think that there was something half human, and altogether uncanny, in the look of a large seal as he spins along with his head and half his body out of the water. When they saw one, they prophesied always, in the most doleful fashion, that they were "sartin sum orkard thing wud happen tu sum o' the fishin' craft, or else tu the oyster grounds, fur they'd sin close in-shore one o' them 'ere outlandish seals." Even in the present day, sea-dogs, as they are frequently called, are looked upon with very little favour owing to the sounds proceeding from them, which reach the fishermen at night, sometimes when they lie off the sand-bars, waiting for the tide.

What a mysterious sight to me, in my youth, was that long, dark, oily roller, which I have watched come out of the darkness, lit up by phosphorescent flashes, as it raced towards the shore! The sea meanwhile was calm; no 
waves, at least, were breaking on the beach ; and I heard the sprat-loons howl. How I wondered, and, for the matter of that, still wonder, whence came that mighty roller, and what caused it!

The rising generation live in favoured times ; their way is all made plain and smooth. Picture galleries, collections of natural history, botanical gardens and reading-rooms-all are open to them; and also those noble establishments for the help and care of suffering humanity, our hospitals. And all within quick and easy reach either by water or rail, that marvellous network of iron roads or tracks which run in all directions, above ground and under it. And to think that nearly all these vast changes for the good of our common humanity have taken place in my own time! I have lived to see tradesmen's carts rattling along main streets over the very spots where I used to get bogged up to the waist, looking after snipes. More changes will, and must, come yet to give living-room to the increasing population. I must not touch on that question, but I believe that the class to which I belong will yet have sufficient to say about it. The spirit of unrest has reached even into the heart of 
the Weald. "They doan't know what's comin'," they say often enough. The fact is, the thin end of the wedge has been driven in, and soon recollections such as mine will only exist in print.

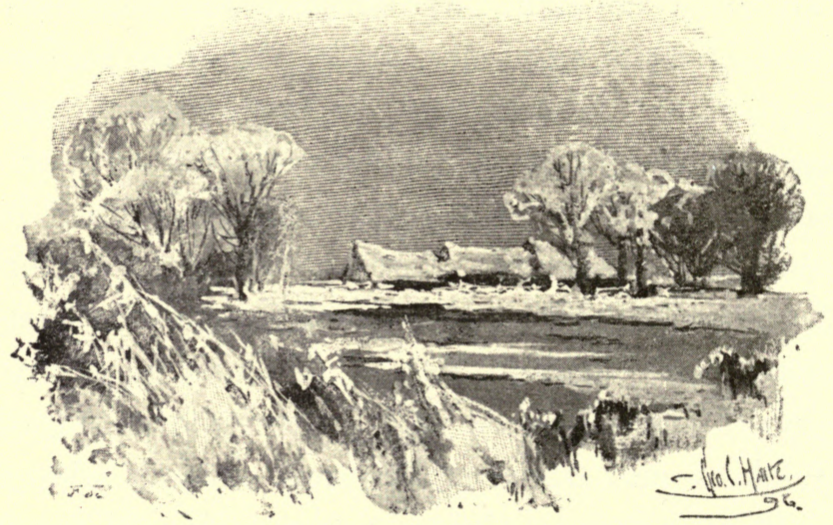

Printed by Ballantyne, Hanson \& Co.

Edinburgh and London 

meivniv to the circulation desk or any

University of California Library

or to the

NORTHERN REGIONAL LIBRARY FACILITY

Bldg. 400, Richmond Field Station

University of California

Richmond, CA 94804-4698

ALL BOOKS MAY BE RECALLED AFTER 7 DAYS

2-month loans may be renewed by calling

(510) 642-6753

1-year loans may be recharged by bringing books to NRLF

Renewals and recharges may be made 4 days prior to due date

DUE AS STAMPED BELOW

OCT 131993 
